Prepared in cooperation with the South Central Climate Adaptation Science Center

\title{
Streamflow Response to Potential Changes in Climate in the Upper Rio Grande Basin
}

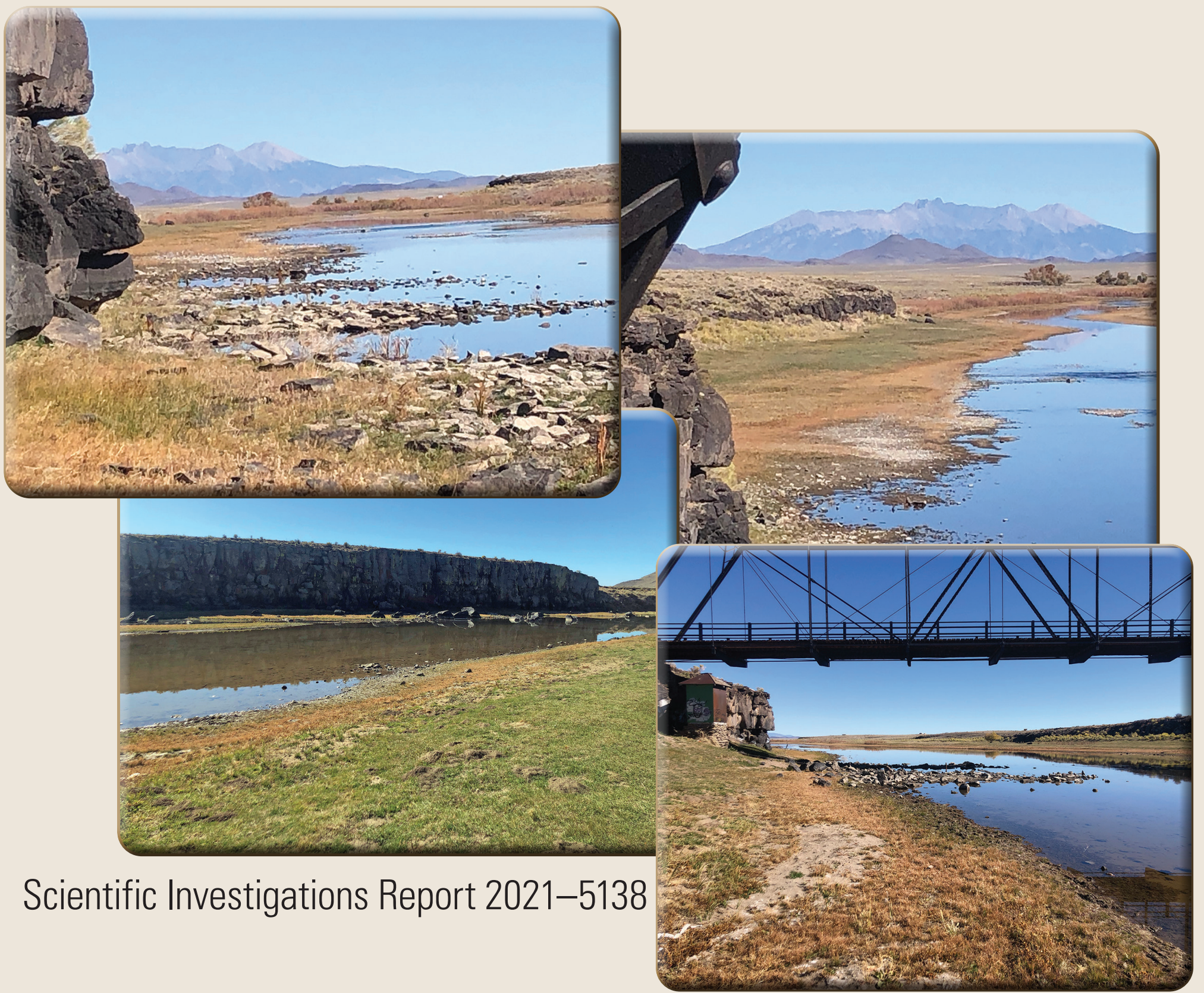

U.S. Department of the Interior

U.S. Geological Survey 
Cover. Photographs showing the Rio Grande from and near the bridge at Lobatos, Colorado, near the Colorado-New Mexico State line. The Sangre de Cristo Mountains are shown in the background in the views oriented north from the bridge. All photographs by C. David Moeser, U.S. Geological Survey, 2020. 


\section{Streamflow Response to Potential Changes in Climate in the Upper Rio Grande Basin}

By C. David Moeser, Shaleene B. Chavarria, and Adrienne M. Wootten

Prepared in cooperation with the South Central Climate Adaptation

Science Center

Scientific Investigations Report 2021-5138 


\section{U.S. Geological Survey, Reston, Virginia: 2021}

For more information on the USGS - the Federal source for science about the Earth, its natural and living resources, natural hazards, and the environment-visit https://www.usgs.gov or call 1-888-ASK-USGS.

For an overview of USGS information products, including maps, imagery, and publications, visit https://store.usgs.gov/.

Any use of trade, firm, or product names is for descriptive purposes only and does not imply endorsement by the U.S. Government.

Although this information product, for the most part, is in the public domain, it also may contain copyrighted materials as noted in the text. Permission to reproduce copyrighted items must be secured from the copyright owner.

Suggested citation:

Moeser, C.D., Chavarria, S.B., and Wootten, A.M., 2021, Streamflow response to potential changes in climate in the Upper Rio Grande Basin: U.S. Geological Survey Scientific Investigations Report 2021-5138, 41 p., https://doi.org/ 10.3133/sir20215138.

Associated data for this publication:

Chavarria, S.B., Moeser, C.D., Ball, G.P., and Shephard, Z.M., 2020, Hydrologic simulations using projected climate data as input to the Precipitation-Runoff Modeling System (PRMS) in the Upper Rio Grande Basin (ver. 2.0,

September 2021): U.S. Geological Survey data release, https://doi.org/10.5066/P9ML930B.

ISSN 2328-0328 (online) 


\section{Acknowledgments}

This research was funded by the Department of the Interior South Central Climate Adaptation Science Center and the U.S. Army Corps of Engineers.

The authors wish to thank Jacob LaFontaine, Steve Markstrom, and Steve Regan of the U.S. Geological Survey for providing insight in developing and calibrating the Precipitation-Runoff Modeling System (PRMS) model. 



\section{Contents}

Acknowledgments ……......................................................................................................................

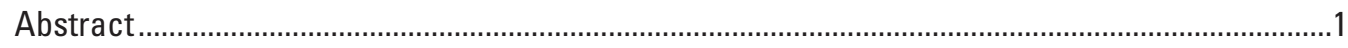

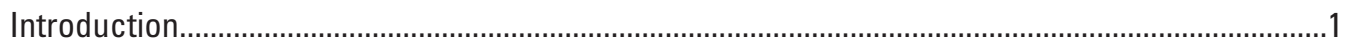

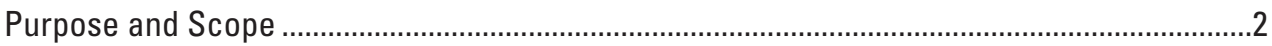

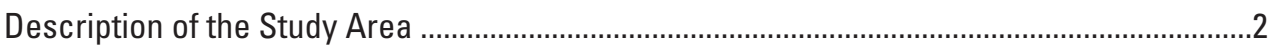

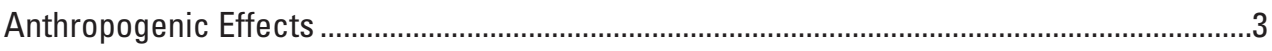

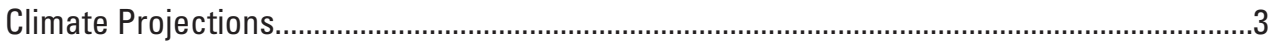

Previous Studies of the Impacts of Climate Change on Rio Grande Streamflow ......................5

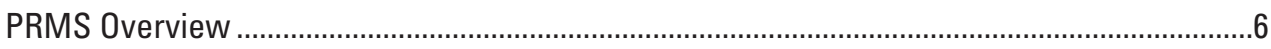

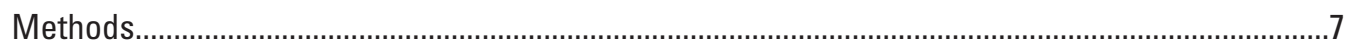

PRMS Model Design and Calibration .................................................................................

National Hydrologic Model Infrastructure .................................................................

Near-Native Subbasins Used for Calibration ..................................................................

Sensitivity Analysis .......................................................................................................

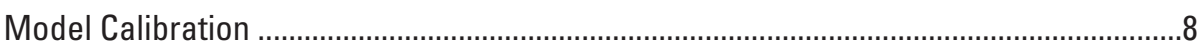

Parameter Distribution to Gaged and Ungaged Subbasins.............................................8

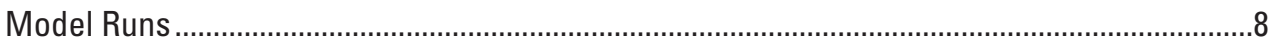

Representative Concentration Pathways (RCPs) ……...............................................

Global Climate Models ..............................................................................................

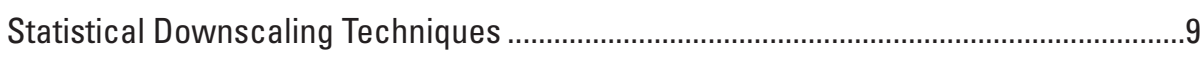

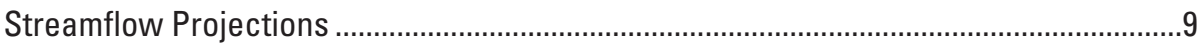

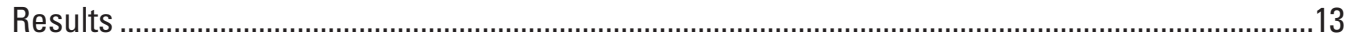

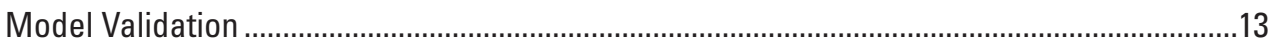

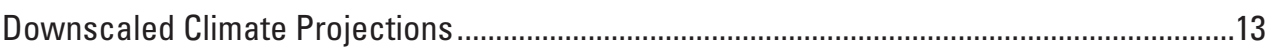

Projected Change in Temperature and Precipitation ..........................................................15

Projected Change in Streamflow at Streamgage Locations in the Upper Rio

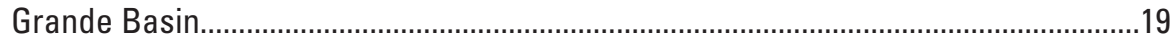

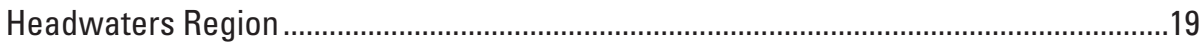

Projected Changes in Streamflow Volume ............................................................19

Projected Changes in Streamflow Timing ...........................................................25

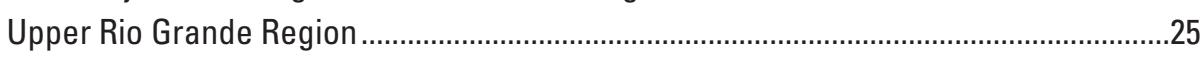

Projected Changes in Streamflow Volume .......................................................... 25

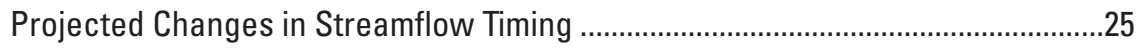

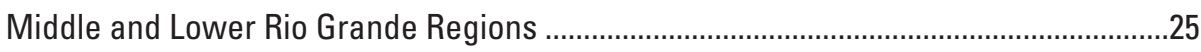

Projected Changes in Streamflow Volume ...........................................................27

Projected Changes in Streamflow Timing .............................................................27

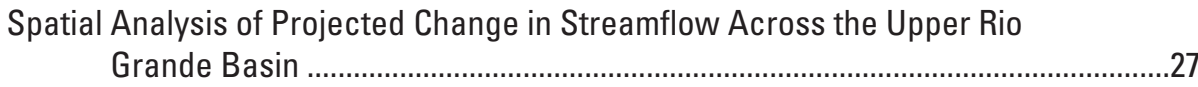

Projected Changes in Streamflow Volume ...........................................................27

Projected Changes in Streamflow Timing ...........................................................27

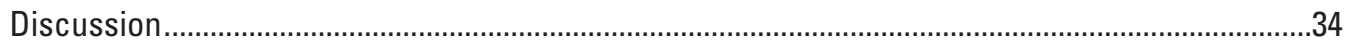

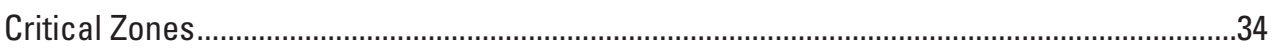

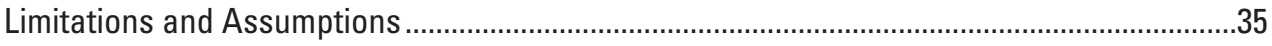

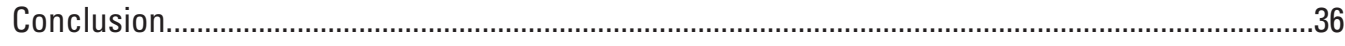

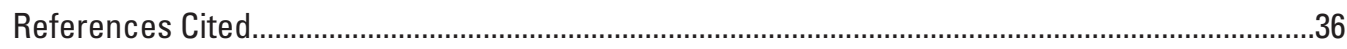




\section{Figures}

1. Map showing Upper Rio Grande Basin and components of the Precipitation-Runoff Modeling System model including basin regions, hydrologic response units, stream segments, near-native subbasins, near-native streamgages, and main-stem streamgages

2. Graphs showing comparison of the simulated streamflow representing naturalized mean monthly flow to observed streamflow at streamgages on the main stem of the Rio Grande between 1980 and 2015 in the Upper Rio Grande Basin, Colorado, New Mexico, and Texas

3. Maps showing projected changes in annual average high temperature from the ensemble mean of all general circulation models using representative concentration pathways 2.6, 4.5, and 8.5 and downscaling methods.

4. Maps showing projected changes in precipitation during monsoon season from the ensemble mean of all general circulation models using representative concentration pathways $2.6,4.5$, and 8.5 and downscaling methods.

5. Maps showing projected changes in precipitation during snowmelt season from the ensemble mean of all general circulation models using representative concentration pathways $2.6,4.5$, and 8.5 and downscaling methods.

6. Graphs showing simulated hydrographs of main-stem gages from upstream to downstream using the ensemble mean of all general circulation models and downscaling methods using representative concentration pathways 2.6, 4.5 , and 8.5 .

7. Graphs showing simulated hydrographs of near-native gages from upstream to downstream using the ensemble mean of all general circulation models and downscaling methods using representative concentration pathways 2.6, 4.5 , and 8.5 .

8. Graphs showing simulated hydrographs of near-native gages from upstream to downstream using the ensemble mean of all general circulation models and downscaling methods using representative concentration pathways 2.6, 4.5, and 8.5.

9. Boxplots showing differences in streamflow timing between historical observations and model projections and percent differences in cumulative streamflow volume for three future time periods based on the representative concentration pathways 2.6, 4.5, and 8.5 on Rio Grande main-stem streamgages in the Upper Rio Grande Basin.

10. Boxplots showing differences in streamflow timing between historical observations and model projections and percent differences in cumulative streamflow volume for three future time periods based on the representative concentration pathways $2.6,4.5$, and 8.5 for near-native streamgages in the Upper Rio Grande Basin .

11. Boxplots showing differences in streamflow timing between historical observations and model projections and percent differences in cumulative streamflow volume for three future time periods based on the representative concentration pathways $2.6,4.5$, and 8.5 for near-native streamgages in the Upper Rio Grande Basin.

12. Maps showing projected change in cumulative streamflow volume for all Precipitation-Runoff Modeling System stream segments for the water year using the ensemble mean of general circulation models and downscaling scenarios for three future time periods based on the representative concentration pathways $2.6,4.5$, and 8.5 . 
13. Maps showing projected change in cumulative streamflow volume for all Precipitation-Runoff Modeling System stream segments for snowmelt season using the ensemble mean of general circulation models and downscaling scenarios for three future time periods based on the representative concentration pathways $2.6,4.5$, and 8.5 .

14. Maps showing projected change in cumulative streamflow for all Precipitation-Runoff Modeling System stream segments for monsoon season using the ensemble mean of general circulation models and downscaling scenarios for three future time periods based on the representative concentration pathways $2.6,4.5$, and 8.5 ...

15. Maps showing projected change in streamflow timing for all Precipitation-Runoff Modeling System stream segments for the water year using the ensemble mean of general circulation models and downscaling scenarios for three future time periods based on the representative concentration pathways 2.6, 4.5, and 8.5.

16. Map showing projected change in streamflow timing for all Precipitation-Runoff Modeling System stream segments for the snowmelt season using the ensemble mean of general circulation models and downscaling scenarios for three future time periods based on the representative concentration pathways 2.6, 4.5, and 8.5......

17. Maps showing projected change in streamflow timing for all

Precipitation-Runoff Modeling System stream segments for the monsoon season using the ensemble mean of general circulation models and downscaling scenarios for three future time periods based on the representative concentration pathways $2.6,4.5$, and 8.5 .

\section{Tables}

1. Streamgages on the main stem of the Rio Grande and in near-native subbasins simulated by the Precipitation-Runoff Modeling System model for the Upper Rio Grande Basin, Colorado, New Mexico, and Texas.

2. Projected changes in delta streamflow timing between future time periods in the Precipitation-Runoff Modeling System model and representative concentration pathways on an annual and seasonal basis for streamgages on the main stem of the Rio Grande and in near-native subbasins in the Upper Rio Grande Basin, Colorado, New Mexico, and Texas

3. Projected changes in delta streamflow volume between future time periods in the Precipitation-Runoff Modeling System model and representative concentration pathways on an annual and seasonal basis for streamgages on the main stem of the Rio Grande and in near-native subbasins in the Upper Rio Grande Basin, Colorado, New Mexico, and Texas

4. Monthly model validation statistics comparing the initial National Hydrologic Model and the calibrated model

5. Average projected changes in total precipitation during the monsoon and snowmelt seasons across the Upper Rio Grande Basin for each future time period by representative concentration pathways $2.6,4.5$, and 8.5 and downscaling methods. 


\section{Conversion Factors}

U.S. customary units to International System of Units

\begin{tabular}{|c|c|c|}
\hline Multiply & By & To obtain \\
\hline \multicolumn{3}{|c|}{ Length } \\
\hline inch (in.) & 2.54 & centimeter $(\mathrm{cm})$ \\
\hline inch (in.) & 25.4 & millimeter (mm) \\
\hline foot $(\mathrm{ft})$ & 0.3048 & meter $(\mathrm{m})$ \\
\hline mile (mi) & 1.609 & kilometer (km) \\
\hline yard (yd) & 0.9144 & meter $(\mathrm{m})$ \\
\hline \multicolumn{3}{|c|}{ Area } \\
\hline acre & 4,047 & square meter $\left(\mathrm{m}^{2}\right)$ \\
\hline acre & 0.4047 & hectare (ha) \\
\hline acre & 0.4047 & square hectometer $\left(\mathrm{hm}^{2}\right)$ \\
\hline acre & 0.004047 & square kilometer $\left(\mathrm{km}^{2}\right)$ \\
\hline square mile $\left(\mathrm{mi}^{2}\right)$ & 259.0 & hectare (ha) \\
\hline square mile $\left(\mathrm{mi}^{2}\right)$ & 2.590 & square kilometer $\left(\mathrm{km}^{2}\right)$ \\
\hline \multicolumn{3}{|c|}{ Volume } \\
\hline cubic foot $\left(\mathrm{ft}^{3}\right)$ & 28.32 & cubic decimeter $\left(\mathrm{dm}^{3}\right)$ \\
\hline cubic foot $\left(\mathrm{ft}^{3}\right)$ & 0.02832 & cubic meter $\left(\mathrm{m}^{3}\right)$ \\
\hline cubic yard $\left(\mathrm{yd}^{3}\right)$ & 0.7646 & cubic meter $\left(\mathrm{m}^{3}\right)$ \\
\hline acre-foot (acre-ft) & 1,233 & cubic meter $\left(\mathrm{m}^{3}\right)$ \\
\hline acre-foot (acre-ft) & 0.001233 & cubic hectometer $\left(\mathrm{hm}^{3}\right)$ \\
\hline \multicolumn{3}{|c|}{ Flow rate } \\
\hline acre-foot per day (acre-ft/d) & 0.01427 & cubic meter per second $\left(\mathrm{m}^{3} / \mathrm{s}\right)$ \\
\hline acre-foot per year (acre-ft/yr) & 1,233 & cubic meter per year (m³/yr) \\
\hline acre-foot per year (acre-ft/yr) & 0.001233 & cubic hectometer per year $\left(\mathrm{hm}^{3} / \mathrm{yr}\right)$ \\
\hline cubic foot per second $\left(\mathrm{ft}^{3} / \mathrm{s}\right)$ & 0.02832 & cubic meter per second $\left(\mathrm{m}^{3} / \mathrm{s}\right)$ \\
\hline
\end{tabular}

International System of Units to U.S. customary units

\begin{tabular}{lll}
\hline \multicolumn{1}{c}{ Multiply } & \multicolumn{1}{c}{ By } & \multicolumn{1}{c}{ To obtain } \\
\hline centimeter $(\mathrm{cm})$ & Length & \\
millimeter $(\mathrm{mm})$ & 0.3937 & inch (in.) \\
meter $(\mathrm{m})$ & 0.03937 & inch (in.) \\
kilometer $(\mathrm{km})$ & 3.281 & foot (ft) \\
meter $(\mathrm{m})$ & 0.6214 & mile (mi) \\
& 1.094 & yard (yd) \\
\hline square meter $\left(\mathrm{m}^{2}\right)$ & Area & \\
hectare (ha) & 0.0002471 & acre \\
square hectometer $\left(\mathrm{hm}^{2}\right)$ & 2.471 & acre \\
square kilometer $\left(\mathrm{km}^{2}\right)$ & 2.471 & acre \\
hectare (ha) & 247.1 & acre \\
square kilometer $\left(\mathrm{km}^{2}\right)$ & 0.003861 & square mile $\left(\mathrm{mi}^{2}\right)$ \\
\hline
\end{tabular}




\begin{tabular}{lll}
\hline \multicolumn{1}{c}{ Multiply } & \multicolumn{1}{c}{ By } & \multicolumn{1}{c}{ To obtain } \\
\hline & Volume & \\
\hline cubic decimeter $\left(\mathrm{dm}^{3}\right)$ & 0.03531 & cubic foot $\left(\mathrm{ft}^{3}\right)$ \\
cubic meter $\left(\mathrm{m}^{3}\right)$ & 35.31 & cubic foot $\left(\mathrm{ft}^{3}\right)$ \\
cubic meter $\left(\mathrm{m}^{3}\right)$ & 0.0008107 & acre-foot $($ acre-ft) \\
cubic hectometer $\left(\mathrm{hm}^{3}\right)$ & 810.7 & acre-foot $($ acre-ft) \\
\hline & Flow rate & \\
\hline cubic meter per second $\left(\mathrm{m}^{3} / \mathrm{s}\right)$ & 70.07 & acre-foot per day $(\mathrm{acre}-\mathrm{ft} / \mathrm{d})$ \\
cubic meter per year $\left(\mathrm{m}^{3} / \mathrm{yr}\right)$ & 0.000811 & acre-foot per year $(\mathrm{acre}-\mathrm{ft} / \mathrm{yr})$ \\
cubic hectometer per year $(\mathrm{hm} / \mathrm{yr})$ & 811.03 & acre-foot per year $(\mathrm{acre}-\mathrm{ft} / \mathrm{yr})$ \\
cubic meter per second $\left(\mathrm{m}^{3} / \mathrm{s}\right)$ & 35.31 & cubic foot per second $(\mathrm{ft} / \mathrm{s})$ \\
\hline
\end{tabular}

Temperature in degrees Celsius $\left({ }^{\circ} \mathrm{C}\right)$ may be converted to degrees Fahrenheit $\left({ }^{\circ} \mathrm{F}\right)$ as follows: ${ }^{\circ} \mathrm{F}=\left(1.8 \times{ }^{\circ} \mathrm{C}\right)+32$.

Temperature in degrees Fahrenheit $\left({ }^{\circ} \mathrm{F}\right)$ may be converted to degrees Celsius $\left({ }^{\circ} \mathrm{C}\right)$ as follows: ${ }^{\circ} \mathrm{C}=\left({ }^{\circ} \mathrm{F}-32\right) / 1.8$.

\section{Datum}

Vertical coordinate information is referenced to the North American Vertical Datum of 1988 (NAVD 88).

Horizontal coordinate information is referenced to North American Datum of 1983 (NAD 83).

Altitude, as used in this report, refers to distance above the vertical datum. 


\section{Abbreviations}

AR5

Fifth Intergovernmental Panel on Climate Change Assessment Report

CCSM4

Community Climate System Model version 4

CMIP3

Coupled Model Intercomparison Project phase 3

CMIP5

Coupled Model Intercomparison Project phase 5

DeltaSD

Delta method

EDOM

equidistant quantile mapping method

FAST

Fourier amplitude sensitivity test

GCM

general circulation model

HRU

hydrologic response unit

IPCC

Intergovernmental Panel on Climate Change

MIROC5

Model for Interdisciplinary Research on Climate version 5

MPI-ESM-LR

Max-Planck-Institute Earth System Model

NHM

National Hydrologic Model

NMOSE/ISC

New Mexico Office of the State Engineer/Interstate Stream Commission

PARM piecewise asynchronous regression method

PRMS

Precipitation-Runoff Modeling System

$\mathrm{RCP}$

representative concentration pathway

SCA

snow cover area

USGS

U.S. Geological Survey

WOCC

State of New Mexico Water Quality Control Commission 


\title{
Streamflow Response to Potential Changes in Climate in the Upper Rio Grande Basin
}

\author{
By C. David Moeser, ${ }^{1}$ Shaleene B. Chavarria, ${ }^{1}$ and Adrienne M. Wootten ${ }^{2}$
}

\section{Abstract}

The Rio Grande is a vital water source for the southwestern States of Colorado, New Mexico, and Texas and for northern Mexico. The river serves as the primary source of water for irrigation in the region, has many environmental and recreational uses, and is used by more than 13 million people including those in the Cities of Albuquerque and Las Cruces, New Mexico; El Paso, Texas; and Ciudad Juárez, Chihuahua, Mexico. However, concern is growing over the increasing gap between water supply and demand in the Upper Rio Grande Basin. As populations increase and agricultural crop patterns change, demands for water are increasing, at the same time the region is undergoing a decrease in supply due to drought and climate change.

Quantifying the impact of projected climate change on Rio Grande streamflow is difficult because of numerous anthropogenic influences on the hydrologic system. The conveyance and use of surface water in the Upper Rio Grande Basin are achieved through an engineered system of reservoirs, diversions, and irrigation canals designed to deliver water to agricultural, municipal, and industrial users, who greatly reduce the cumulative volume of water in the river. For example, streamflow at Fort Quitman, Tex., the southernmost point of the Upper Rio Grande Basin, has undergone a 95-percent reduction in flow relative to the river's native state, and some stretches of the river can intermittently go dry. Because streamflow in the basin is highly altered, disentangling the impacts of climate change and changes in streamflow due to anthropogenic influences such as dams, diversions, and other forms of water use is difficult. Therefore, a model of naturalized flow was developed to determine to what degree changes in streamflow can be attributed to potential changes in future temperature and precipitation without quantifying future changes in anthropogenic influences. This study, conducted by the U.S. Geological Survey in cooperation with the South Central Climate Adaptation Science Center and the U.S. Army Corps of Engineers, included the development and calibration

${ }^{1}$ U.S. Geological Survey

${ }^{2}$ South Central Climate Adaptation Science Center at the University of Oklahoma of a watershed model of the Upper Rio Grande Basin using the Precipitation-Runoff Modeling System to simulate naturalized streamflow conditions for historical and future time periods.

\section{Introduction}

The Rio Grande is a vital water source for the southwestern States of Colorado, New Mexico, and Texas and for northern Mexico. The river serves as the primary source of water for irrigation in the region, has many environmental and recreational uses, and is used by more than 13 million people including those in the Cities of Albuquerque and Las Cruces, New Mexico; El Paso, Texas; and Ciudad Juárez, Mexico (Gonzalez and others, 2018; fig. 1). However, concern is growing over the increasing gap between water supply and demand in the Upper Rio Grande Basin. As populations increase and agricultural crop patterns change, demands for water are increasing, while the region is undergoing a decrease in supply due to drought and climate change (Gonzalez and others, 2018).

Nearly 75 percent of Rio Grande streamflow is derived from seasonal snowpack that accumulates throughout the winter season in the headwaters and other high-elevation areas in the Upper Rio Grande Basin. The remaining percentage is primarily generated by monsoonal rains (Rango, 2006). Studies indicate that increasing temperatures across the Western United States are already affecting streamflow derived from seasonal snowpack (Clow, 2010; Dettinger and others, 2015). The most recent U.S. National Climate Assessment suggests that temperatures in the southwest will continue to rise, resulting in more snow falling as rain in mid to high elevations and increasing the probabilities of decadal to multidecadal megadroughts (Gonzalez and others, 2018). Recent trends in Upper Rio Grande streamflow have been toward earlier peak flows from earlier spring snowmelt and increased influence of spring rains on streamflow (Chavarria and Gutzler, 2018). The form of precipitation (rain versus snow) that contributes to streamflow differs from north to south in the study area, which makes it important to understand how future climate will affect streamflow spatially and on a seasonal basis. 
Quantifying the impact of climate change on Rio Grande streamflow is difficult because of several anthropogenic influences on the hydrologic system. The conjunctive use of water in the Upper Rio Grande Basin takes place under a myriad of legal constraints including the Rio Grande Compact agreement between the States, administration of water rights by individual States, an international treaty with Mexico, and several Federal water projects (Paddock, 2001). The conveyance and use of surface water in the basin are achieved through an engineered system of reservoirs, diversions, and irrigation canals designed to deliver water to agricultural, municipal, and industrial users who combine to greatly reduce the cumulative volume of water in the river. For example, streamflow at Fort Quitman, Tex., the southernmost point in the Upper Rio Grande Basin, has undergone a 95-percent reduction in flows relative to the river's native state (Chavarria and others, 2020a), and some stretches of the river intermittently go dry. The growing gap between supply and demand has resulted in continued conflict over water in the region and ongoing litigation among users and Federal, Tribal, State, and local agencies. Future climate, with increasing temperatures and potential shifts in timing and amount of precipitation, may exacerbate this gap. Trends in Upper Rio Grande Basin streamflow in the past 60 years have been toward earlier peak flows from earlier spring snowmelt and increased influence of spring rains on streamflow (Chavarria and Gutzler, 2018), which makes it important to understand how future climate will affect both snowmelt and runoff contributions to surfacewater supply.

To gain insight into the magnitude of anthropogenic influence on Rio Grande streamflow, a watershed model was developed using the Precipitation-Runoff Modeling System (PRMS) and calibrated for the Upper Rio Grande Basin to simulate naturalized streamflow conditions for the historical period from 1980 to 2015 (Chavarria and others, 2020a). The model quantifies the spatial and temporal distribution of water-budget components in a basin and can be used to assess the effects of climate and land use on water resource availability and timing by removing the anthropogenic influence of dams and diversions on streamflow. Because streamflow in the basin is highly altered, disentangling the impacts of climate change and changes in streamflow due to anthropogenic influences such as dams, diversions, and other forms of water use is difficult. Therefore, a model of naturalized flow was developed to determine how much of a change in streamflow can be attributed to changes in future temperature and precipitation without having to quantify future changes in anthropogenic influences.

In this study, the Upper Rio Grande Basin PRMS model was run with projected climate data to produce a set of streamflow projections through the year 2099 that represent potential future changes in Rio Grande streamflow due to changes in climate. Projected temperature and precipitation data used as input to PRMS were derived from three general circulation models (GCMs), which simulate future climate based on three representative concentration pathways (RCPs), and downscaled using three different methods. To arrive at potential climate-induced impacts, simulated streamflow for the model historical period (1981-2015) was subtracted from three simulated future time periods, and an analysis of changes in streamflow volume and timing was conducted for the Rio Grande and its tributaries. Quantifying potential changes in future streamflow on the Rio Grande and its tributaries can help water managers formulate plans to deal with future imbalances in water supply and demand in the basin.

\section{Purpose and Scope}

This report documents the calibration, use, and analysis of a PRMS model for the Upper Rio Grande Basin (fig. 1) forced with an ensemble of precipitation and temperature data originating from three GCMs from the Coupled Model Intercomparison Project phase 5 (CMIP5) and three downscaling methods, which represent three Intergovernmental Panel on Climate Change (IPCC) based RCPs: RCP 2.6, RCP 4.5, and RCP 8.5 (IPCC, 2019). This gave an ensemble output of 9 scenarios per RCP scenario (total of 27). The model was then run at a daily time step for each ensemble member for each RCP scenario between 1981 and 2099. The model output was then parsed into four time periods: the historical period between 1981 and 2005, future time period 1 between 2022 and 2047, future time period 2 between 2048 and 2073, and future time period 3 between 2074 and 2099. The difference between the historical period and each future time period was calculated for each ensemble member and RCP scenario. The mean amount of change for each data ensemble at each future time period and RCP was then calculated. This report presents the estimated amount of change in the total volume and timing of streamflow for the entire watershed at specific locations on the river and its tributaries for the three RCPs and future time periods.

\section{Description of the Study Area}

In the Upper Rio Grande Basin study area, the Rio Grande flows approximately 650 miles (mi) from the headwaters in Colorado to Fort Quitman, Tex., draining the 32,000-square-mile ( $\mathrm{mi}^{2}$ ) Upper Rio Grande Basin (fig. 1). The Upper Rio Grande Basin spans parts of three States and northern Mexico and is in an arid to semiarid region where disputes over water shortages have existed for more than 100 years. Basin topography varies from the forested mountains of the headwaters to the riparian forests and high desert of central New Mexico to deserts along the boundary between Texas and Mexico (Llewellyn and Vaddey, 2013).

Climate in the basin varies with elevation and latitude, and this variation influences streamflow generation. Subbasins in the northern part of the Upper Rio Grande Basin produce most of the streamflow volume in spring and early summer as the snow melts. Most of the streamflow volume in subbasins in the southern part of the basin is driven by the summer monsoon. 
The Upper Rio Grande Basin was divided into four distinct regions for this study: the headwaters region, the Upper Rio Grande region, the Middle Rio Grande region, and the Lower Rio Grande region (fig. 1).

In the headwaters region of the basin (fig. 1), north of the Colorado-New Mexico State line, elevations range from about 7,500 feet (ft) to more than 14,000 ft (DiNatale Water Consultants, 2014). Mean annual temperatures in the region range from 24 to 53 degrees Fahrenheit $\left({ }^{\circ} \mathrm{F}\right)$, and mean annual precipitation ranges from 17 to 40 inches (in.), with most of the precipitation falling as snow at high elevations (Llewellyn and Vaddey, 2013; Vose and others, 2014). Seasonal snowpack that builds throughout the winter in the San Juan and Sangre de Cristo Mountains contributes 60-75 percent of Rio Grande streamflow (Rango, 2006; Llewellyn and Vaddey, 2013).

The Upper Rio Grande region (fig. 1), as defined in this report, extends from the Colorado-New Mexico State line south to the town of Bernalillo, N. Mex. Elevations in the Upper Rio Grande region range from about 5,000 ft to more than 12,000 ft (State of New Mexico Water Quality Control Commission [WQCC], 2002). Mean annual temperatures in the region range from 45 to $55^{\circ} \mathrm{F}$, with lower temperatures occurring at mid to high elevations (New Mexico Office of the State Engineer/Interstate Stream Commission [NMOSE/ISC], 2017). Precipitation in the region is highly variable, falling as snow in the winter and as rain in the summer, when it is driven by the monsoonal weather pattern. Mean annual precipitation ranges from more than $40 \mathrm{in}$. in the mountainous regions to about $10 \mathrm{in}$. in the valley along the Rio Grande (NMOSE/ ISC, 2017). Most of the perennial tributaries to the Rio Grande in the New Mexico portion of the basin are contained within the Upper Rio Grande region, and major tributaries contribute about 25 percent of Rio Grande flow (WQCC, 2002; Llewellyn and Vaddey, 2013). Collectively, about 80-85 percent of Rio Grande flow is generated in the headwaters and Upper Rio Grande regions of the Upper Rio Grande Basin.

The Middle Rio Grande region, which extends within New Mexico from Bernalillo to Elephant Butte Reservoir, south of Socorro, consists of mountainous areas and broad plains (WQCC, 2002). Elevations range from more than $10,000 \mathrm{ft}$ east of Albuquerque, N. Mex., to about 4,000 ft around Socorro. Mean annual temperature in the Middle Rio Grande region ranges from about 50 to $55^{\circ} \mathrm{F}$, and mean annual precipitation ranges from $8 \mathrm{in}$. in the valley to about $30 \mathrm{in}$. at higher elevations (NMOSE/ISC, 2017). Rio Grande flow in the region is sustained primarily by flow generated upstream and from the Arroyo Chico (table 1; fig. 1; site ID 0340500) and Rio Puerco (table 1; fig. 1; site ID 08334000) Basins (WQCC, 2002).

The Lower Rio Grande region, which comprises areas south of Elephant Butte Reservoir, is an arid region in which flow in the Rio Grande is influenced primarily by the summer monsoon. Elevations in the region range from about $10,000 \mathrm{ft}$ to about $3,800 \mathrm{ft}$ in the southern part of the basin (WQCC, 2002). Mean annual temperatures range from 50 to $75^{\circ} \mathrm{F}$, and summer temperatures can exceed $100^{\circ} \mathrm{F}$ at lower elevations
(NMOSE/ISC, 2017). Mean annual precipitation varies from about 8 to 18 in., with most precipitation falling at the higher elevations (NMOSE/ISC, 2017). Flow in Rio Grande tributaries in the Lower Rio Grande region is predominantly ephemeral (WQCC, 2002).

\section{Anthropogenic Effects}

The Rio Grande is a highly managed system where the conjunctive use of water in the basin takes place under a myriad of legal constraints including the Rio Grande Compact agreement between the States, administration of water rights by individual States, an international treaty with Mexico, and Federal water projects (Paddock, 2001). The conveyance and use of surface water in the basin are achieved through an engineered system of reservoirs, diversions, and irrigation canals designed to deliver water to agricultural, municipal, and industrial users, all of which combine to greatly reduce the cumulative volume of water in the river.

The compact apportions water to Colorado, New Mexico, and Texas, and an international treaty annually allocates up to 60,000 acre-feet (acre-ft) of Rio Grande water to Mexico (Paddock, 2001). Surface-water sources for the Upper Rio Grande Basin include within-basin water, as well as approximately 96,200 acre-ft of water imported from the Colorado River Basin through the San Juan-Chama Project (DiNatale Water Consultants, 2014). San Juan-Chama Project water is diverted from a portion of the Colorado River Basin and conveyed by tunnel into the Upper Rio Grande Basin (Glaser, 1998). San Juan-Chama Project water is allocated to many of the major cities and irrigation districts in the basin above Elephant Butte Reservoir. San Juan-Chama pipeline construction was completed in 2008, and until recently, many of the cities and irrigation districts have not been able to use their San Juan-Chama Project allotments. In addition, approximately 12,000 acre-ft of water per year is diverted from the San Luis Valley closed basin in Colorado to the Rio Grande above the Colorado-New Mexico State line, where it is used to help offset groundwater use and to meet obligations of the compact (DiNatale Water Consultants, 2014). Water operations and management in the Upper Rio Grande Basin are complex because of the different sources of water (withinbasin and imported), numerous reservoirs, stream-aquifer relations, and legal constraints emphasizing the importance of a model of naturalized flow to estimate the effects of potential future changes in climate.

\section{Climate Projections}

In this and other studies looking at the impact of climate change on water resources, climate projections are often used to drive hydrologic models and produce streamflow projections. Climate projections are developed through the use of GCMs. Climate scenarios used in this study were simulated using three GCMs, which simulate future climate based on 


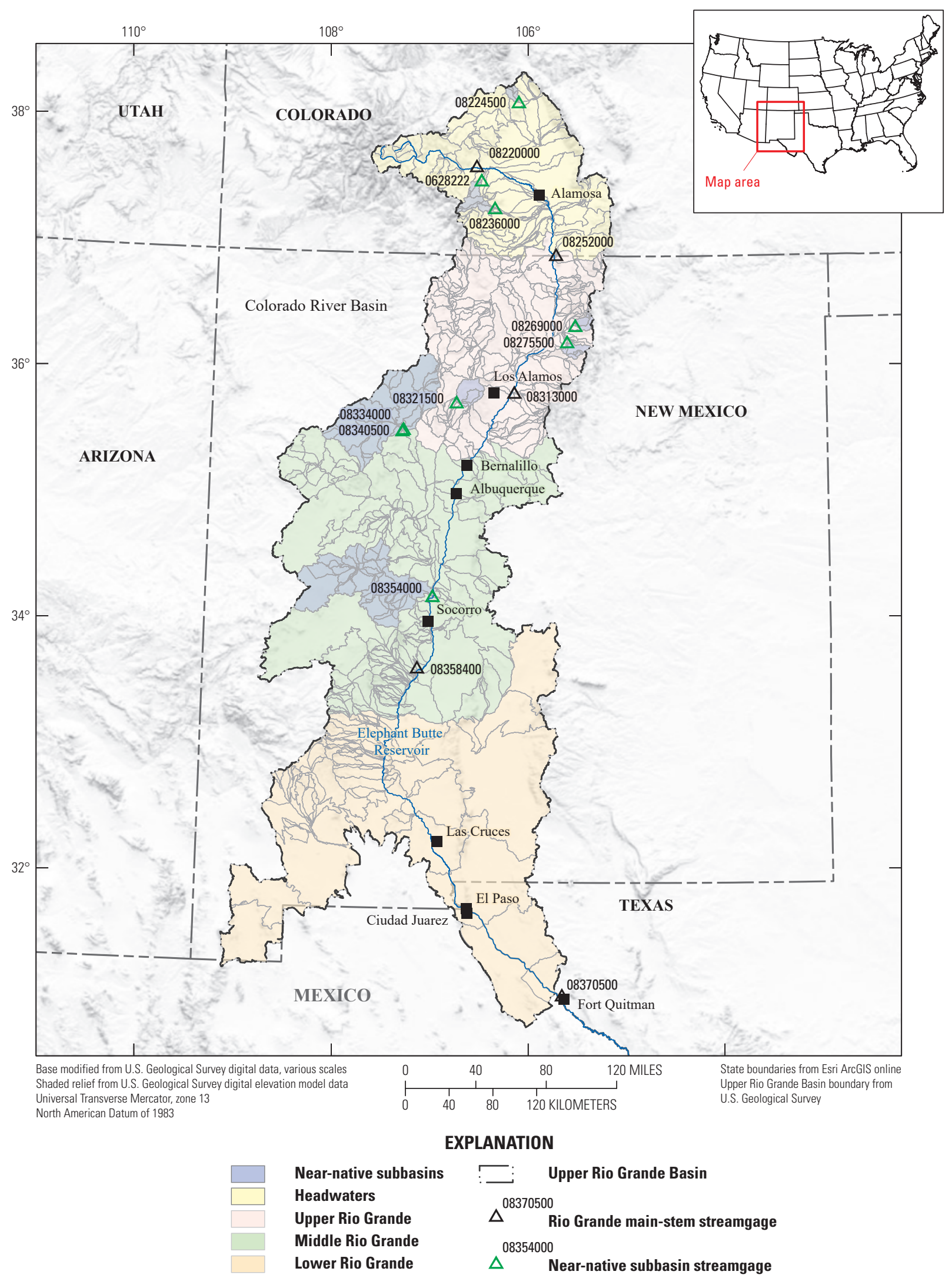

Figure 1. Upper Rio Grande Basin and components of the Precipitation-Runoff Modeling System (PRMS) model including basin regions, hydrologic response units (light-gray polygons), stream segments (gray lines), near-native subbasins, near-native streamgages, and main-stem streamgages. 
three RCPs, that were statistically downscaled for regional use by using three different downscaling methods. GCMs simulate nonstationary climatic effects on precipitation and temperature and provide useful projections of future climate based upon a specific RCP. The RCPs are greenhouse gas concentration trajectories that describe different potential climate futures. However, GCMs also simulate climate at a resolution of 100 kilometers $(\mathrm{km})$ or more, which often is unsuitable for local management assessments and decisions. Downscaling is used to translate the GCM resolution to local-scale processes (Gettelman and Rood, 2016).

GCMs are numerical models that use known physical laws and relations to simulate the general climate patterns of the planet. The GCMs are similar to models used in weather forecasting but focus on capturing changes to the climate over long periods of time (50-100 years or more), whereas weather forecasting focuses on predicting weather events over much shorter time scales. Although each GCM simulates the same fundamental equations, there are processes of the climate system that are not fully understood. For example, it is well understood that the climate system is sensitive to emissions of greenhouse gases, but there is a question of exactly how sensitive the climate system is to the emissions. As such, there are numerous GCMs reflecting different levels of climate sensitivity along with other processes that are not fully understood. Each GCM can be broken into multiple components (atmosphere, land, ocean), but all function similarly. A GCM works by discretizing the planet into a grid of boxes of some size (commonly referred to as the "model resolution") and solving a series of equations at each grid point and time. All GCMs solve for the basic equations that describe the conservation of momentum, energy, and mass for precipitation on Earth and water vapor in the atmosphere. GCMs also include vertical layers into the atmosphere and ocean, but the model resolution is typically greater than $100 \mathrm{~km}$. The grid spacing and processes simulated in a GCM allow the model to simulate the general circulation of the atmosphere and ocean (Hartmann, 1994).

To project future changes to the climate, the GCMs make use of the RCPs (van Vuuren and others, 2011; IPCC, 2019). The RCPs consider specifically the radiative forcing applied to the climate system. Radiative forcing is defined as "a change in the balance between incoming solar radiation and outgoing infrared (that is, thermal) radiation" (U.S. Environmental Protection Agency, 2020). In general, a greater amount of radiative forcing applied to the climate system will result in a greater increase in global mean temperatures by the year 2100 . The RCPs provide time series of emissions and concentrations of greenhouse gases, aerosols, and chemically active gases, along with land use and land cover changes (Moss and others, 2008, 2010; IPCC, 2020). A range of RCPs were produced for the Fifth Intergovernmental Panel on Climate Change Assessment Report (AR5) and are used as inputs to climate models.
While most GCMs successfully capture large-scale patterns and global temperature responses to greenhouse gas emissions, computational constraints limit the scale at which a GCM can operate. The resolution of GCMs is often too coarse (the model grid boxes are too large) to reflect local or regional processes that affect rivers and streamflow, particularly in complex topography. This limits the usefulness of GCMs to local or regional climate change impact assessments and decision making. The process of downscaling is used to translate the coarse-scale GCM output to the regional or local scale (Rummukainen, 2016; Tabari and others, 2016). Statistical downscaling is a type of downscaling that relies on using the GCM output during a historical period and historical observations to build statistical relations. The statistical relation built during the historical period is applied to the GCM output for the future time period to estimate the future "observations" at local/regional scales. As with the GCMs, there is not one single best approach to statistical downscaling, leading to multiple downscaling techniques that influence local/regional projections (Wootten and others, 2017). The use of multiple GCMs and downscaling techniques is recommended when representing future climate projections because of uncertainty in model predictions associated with individual GCMs and downscaling techniques (Wootten and others, 2014). An ensemble of downscaled GCMs better represent a consensus of forcing data to assess hydrologic response at the local scale than the use of one specific GCM does (Sheshukov and others, 2011; Winkler and others, 2011; Sheshukov and DouglasMankin, 2017).

\section{Previous Studies of the Impacts of Climate Change on Rio Grande Streamflow}

Several studies have estimated the impacts of climate change on Rio Grande streamflow (Hurd and Coonrod, 2012; Llewellyn and Vaddey, 2013; Elias and others, 2015). Hurd and Coonrod (2012) used climate scenarios, a monthly water balance model, and the river basin-scale hydroeconomic model to assess the impacts of climate change on streamflow and the potential economic consequences of changes in the Rio Grande Basin. Precipitation and temperature data from three different GCMs from the IPCC's Coupled Model Intercomparison Project phase 3 (CMIP3) suite of models, forced with a "middle-of-the-road" emissions scenario, were used as input to the monthly water balance model to produce simulations for two future time periods (2020-39 and 2070-89). In this study, the data were not downscaled or bias corrected prior to running the hydrologic model (so scenarios did not account for local differences such as changes in topography), nor was the model calibrated to fully represent naturalized conditions. This work displayed decreases in basin streamflow relative to the historical baseline period (1971-2000). The greatest changes in streamflow occurred in the later simulation period showing 8-29 percent declines in total basin flow and shifts toward earlier annual peak flows by 
about 1 month. The economic response to changes in water resources and population in the basin included increases in the price of water and decreases in economic production, mainly in the agricultural sector.

In a study on the Upper Rio Grande Basin (Elias and others, 2015), a snowmelt runoff model and future climate scenarios were used to evaluate the impacts of future climate on the timing and volume of runoff and changes in snow cover area (SCA) in snow-dominated areas of the basin. In that study, historical and future changes were simulated for 24 subbasin tributaries by using 24 snowmelt runoff models. Models were run with temperature and precipitation data using the warmest climate scenarios from GCMs in CMIP3 and CMIP5 suite of climate models, which were downscaled using bias-correction constructed analogs and station-based bias correction. Model results showed a reduction in SCA for all subbasins in future simulations when compared to the 1990-99 baseline period, with reductions in SCA ranging from 40 to 100 percent. The change in streamflow volume varied by subbasin, with changes ranging from a 30 percent decrease in volume in a hotter, drier climate with peak flows occurring about 14 days earlier to a 57 percent increase in volume in a warmer, wetter climate with peak flows occurring 25 days earlier than in the base period.

An investigation of how climate change might affect water operations was conducted as part of the Upper Rio Grande Impact Assessment by the Bureau of Reclamation (Gangopadhyay and others, 2011; Llewellyn and Vaddey, 2013). An ensemble mean of statistically downscaled CMIP3 climate projections was used as input to the variable infiltration capacity hydrologic model to produce streamflow projections through the year 2100 . The variable infiltration capacity model used in the assessment was applied as it is used in forecasting for the Western United States without further calibration to represent streamflow (actual or naturalized) in the Rio Grande Basin (Gangopadhyay and others, 2011). The streamflow projections were bias corrected and then used as input to the Upper Rio Grande Simulation Model, which simulates the effect of water operations (for example, dam releases, agricultural and municipal diversions, and return flows) on available water. Results of the assessment suggest an average decrease in tributary flows that contribute to Rio Grande flow of about 30 percent with an increase in the variability of monthly and annual flows. Model results displayed variable changes in peak flow timing, with many large headwater subbasins displaying earlier peak flows by approximately 1 month and many minor subbasins outside of the headwaters displaying minor to no changes.

Similar to the studies discussed above, the current study makes use of a hydrologic model and climate projections using selected GCMs from the CMIP5 set of models to simulate the potential effects of future climate on streamflow. The current study differs from the previous studies, however, by using a watershed model that has been calibrated to local conditions to simulate naturalized streamflow and other hydrologic variables at various spatial scales. This means that the models can produce estimates of streamflow or other hydrologic variables for the entire basin, for specified subbasins, or for individual hydrologic response units (HRUs) without needing to account for potential future changes in anthropogenic effects in the basin. In addition, this study uses GCMs that have been specifically selected on the basis of their performance in the region (Bertrand and McPherson, 2019; Wootten and others, 2020).

\section{PRMS Overview}

PRMS is a component of the National Hydrologic Model (NHM) developed by the U.S. Geological Survey (USGS) (Leavesley and others, 1983; Markstrom and others, 2015). PRMS is a deterministic, process-based, distributed-parameter modeling system designed to analyze the effects of precipitation, climate, and land use on streamflow and general basin hydrology on a daily time step. The national-scale framework of the NHM allows for subcatchment modeling using predefined, spatially distributed HRUs (as described by Regan and others, 2018). HRUs partition the model domain into areas with relatively uniform hydrologic response that are based on basin topography, vegetation, soil, and climate. The model input data include precipitation, minimum temperature, and maximum temperature. PRMS represents the hydrologic cycle as 17 interconnected processes (Markstrom and others, 2015). These hydrologic processes are simulated using source code modules within PRMS. In some cases, PRMS has several modules that provide alternative methods of simulating the processes. Hydrologic processes simulated in PRMS are temperature distribution, precipitation distribution, combined climate distribution, solar radiation distribution, transpiration period, potential evapotranspiration, canopy interception, snow, surface runoff, soil zone, groundwater, and streamflow, as well as five model administrative processes (basin definition, cascading flow, solar table, time-series data, and summary). Each module in PRMS uses parameters and variables to simulate hydrologic processes. Parameters are user-specified input values that are constant temporally from year to year and can vary spatially across the landscape (unique values per HRU) or vary by month and HRU (giving [HRUs $\times$ months] unique values) but do not change during the simulation (for example, the area of each HRU is a parameter that does not change during model simulation). Variables are hydrologic states and fluxes that may change with each time step during the simulation (Markstrom and others, 2015). Some variables may be user-input time-series variables (for example, daily precipitation) or internal variables (for example, soil moisture for each HRU), which are calculated by the modules and may be used by other modules as input variables. 


\section{Methods}

\section{PRMS Model Design and Calibration}

PRMS, like many distributed hydrologic models, needs to be calibrated to be applicable to a specific study area. Although PRMS uses a total of 108 input parameters, 72 of these parameters are not typically varied from their initial values, leaving 36 as standard calibration parameters. Each calibration parameter is used within a single hydrologic process module, but because output variables from one module can be used as input variables to other modules, calibration parameters may affect several hydrologic processes (Markstrom and others, 2015). PRMS has more than 200 output variables that represent specific hydrologic responses over time. As a result of both model complexity and the extensive set of parameters, sensitivity analyses for PRMS are both highly complex and essential for successful model application. During model sensitivity analysis, the influence of calibration parameters on output variables is assessed. During model calibration, calibration parameters are adjusted, and output variables are compared to observed hydrologic data to assess model performance.

The following general steps were taken to design a PRMS model that simulated near-native streamflow conditions for the Upper Rio Grande Basin:

1. Develop a model of the Upper Rio Grande Basin based on the USGS NHM infrastructure.

2. Define subbasins within the Upper Rio Grande Basin that have little to no water withdrawals (near-native subbasins; fig. 1).

3. Perform a sensitivity analysis of model parameters in each near-native subbasin.

4. Calibrate the model within each near-native subbasin.

5. Distribute calibrated parameter values to the remaining model domain.

Streamflow estimates were validated from a comparison of simulated values to measured values in each of the nearnative subbasins. Further details and associated data with each step of model calibration and validation in this report can be found in Chavarria and others (2020a, b).

\section{National Hydrologic Model Infrastructure}

A PRMS model based on the NHM infrastructure was initially extracted from the NHM-PRMS application for the Upper Rio Grande Basin. The NHM infrastructure is a repository where all information, including predefined modeling units (HRUs and stream segments), estimated parameters derived from a variety of methods, climate input data, and hydrologic process simulation code, can be obtained to develop a PRMS model for a specified area (Regan and others, $2018,2019)$. The 1,021 HRUs that cover the study area basin were extracted from the NHM along with model parameters and input data.

Initial input parameter values from the NHM database for Upper Rio Grande Basin HRUs were adopted from the Geospatial Fabric of the NHM platform (Viger, 2014; Viger and Bock, 2014; Regan and others, 2018, 2019). Soil parameters were derived from the Soil Survey Geographic Database (Natural Resources Conservation Service, 2013). Land-cover parameters were derived from the 2001 National Land Cover Database (Homer and others, 2007). Subsurface-flow parameters were derived from the map products of Gleeson and others (2011). Determination of values for other model spatial parameters and initial conditions (such as water content of various model storage pools) are described in Regan and others (2018, 2019). The selected parameters (Hay, 2019), maintained in the NHM Parameter Database (Driscoll and others, 2017), were used as initial parameters for the Upper Rio Grande Basin PRMS model.

Model parameters in the San Luis Valley closed basin were not representative of a closed basin. As such, prior to model calibration, several NHM base parameters were altered to prohibit water that does not naturally drain to the Rio Grande either by surface drainage or groundwater discharge from moving out of the closed basin. See Chavarria and others (2020a) for further details.

\section{Near-Native Subbasins Used for Calibration}

In order to represent naturalized flow in the PRMS model, streamflow without anthropogenic effects needs to be quantified. Measured subbasin streamflow from streamgages in the Upper Rio Grande Basin that had at least 5 years of data, had a contributing area greater than $30 \mathrm{mi}^{2}$, and had peak flows greater than 1,000 cubic feet per second were parsed on the basis of upstream water infrastructure and water withdrawals. Of these subbasins, those that had upstream reservoirs or water withdrawals where greater than 5 percent of total annual flow is diverted were removed. A total of nine streamgages were left; these represented a naturalized flow regime and had enough streamflow data for model calibration (see Chavarria and others, 2020a, table 3 therein).

\section{Sensitivity Analysis}

Basin hydrologic processes, such as infiltration, snowmelt runoff, and overland flow, vary according to spatially and temporally varying combinations of land surface and climatological conditions. For example, streamflow from a cold, mountainous basin may reflect a high dependency on snowmelt processes, whereas streamflow from a warmer, lowland basin may reflect greater dependency on evapotranspiration processes. A national-level sensitivity analysis was performed to better understand interactions between PRMS calibration 
parameters and process variables (Markstrom and others, 2016). This analysis used a Fourier amplitude sensitivity test (FAST) to analyze 110,000 subregions, or HRUs, of the conterminous United States for an 11-year period (1990-2000). The FAST analysis used seven fundamental daily streamflow statistics, in which each statistic represented unique information on hydrologic response (Archfield and others, 2014). This sensitivity analysis allowed for a better understanding of key hydrologic processes for an HRU and the dominant parameters that affect each key process to improve runoff modeling within a study area (Markstrom and others, 2016). The FAST results showed that, on average (of 110,000 HRUs in the conterminous United States), 90 percent of the parameter sensitivity to key hydrologic processes in a given HRU usually comes from only 2 to 9 parameters, which is a small subset of the 36 standard calibration parameters. Using the sensitivity analysis to selectively reduce the number of calibration parameters improves understanding of PRMS process-parameter interactions and reduces potential for equifinality (that is, getting the right result for the wrong reasons) by reducing the number of parameters needing adjustment to make an accurate calibration.

As part of a prior study by Douglas-Mankin and Moeser (2019), a platform was created to provide a quasi-graphical user interface to easily query the FAST data by region, HRU, groupings of HRUs, specific aspects of the flow regime, and groupings of flow-regime aspects. This platform allows for quick, site-specific determination of the key parameters and processes and their associated influence on various aspects of the flow regime and permits a more informed, quicker calibration process in which only key processes and affiliated parameters are optimized for an area.

The platform from Douglas-Mankin and Moeser (2019) was used to develop a calibration plan unique to each of the nine near-native subbasins. The calibration plan was developed from a determination of which hydrologic processes and parameters exhibited the greatest influence in simulating streamflow volume, flashiness, and timing. See Chavarria and others (2020a) for further details.

\section{Model Calibration}

For calibration, PRMS was forced with daily precipitation, minimum daily temperature, and maximum daily temperature input data from 1980 to 2015 from Daymet: Daily Surface Weather Data on a 0.62-mi (1-km) Grid for North America, Version 3 (Thornton and others, 2016). Daymet is a collection of gridded estimates of precipitation, temperature, and solar radiation derived by interpolation and extrapolation from observation data at climate stations across North America (Thornton and others, 2016) and a digital elevation model.
Prior to calibration of simulated streamflow in the near-native subbasins, solar radiation and potential evapotranspiration were first calibrated for all HRUs within the model domain by using historical data provided in the normal incident solar radiation atlas and the mean monthly evaporation atlas (Farnsworth and others, 1982) obtained from the USGS Geo Data Portal (Blodgett and others, 2011). Simulated streamflow was then calibrated to streamgage data for each near-native subbasin. A stepwise, multiple-objective process was used, initially outlined in Markstrom and others (2015), that involved calibration of streamflow volume, flashiness, and timing from the optimization of 13 model parameters (derived from the FAST results) using the Luca (Let us calibrate) software (Hay and others, 2006; Hay and Umemoto, 2006).

\section{Parameter Distribution to Gaged and Ungaged Subbasins}

Adjustment factors for each of the calibration parameters within each of the near-native subbasins were distributed to noncalibrated HRUs to represent near-native streamflow conditions at those HRUs falling outside of the near-native basins. An adjustment factor was defined as the difference between the postcalibration value and the precalibration value (initial NHM value). Unique regression equations were created for each near-native subbasin for each parameter adjustment factor (and for each month for parameters indexed by month) from user-defined characteristic(s). These characteristics were defined from unique HRU traits that included soil type, canopy type, canopy density, elevation, and slope. The equations for each parameter at each subbasin were then weighted and spatially interpolated to all noncalibrated HRUs from an inverse distance squared weighting algorithm if the noncalibrated HRU fell within a user-defined distance from each of the subbasins. See Chavarria and others (2020a) for further details.

\section{Model Runs}

The calibrated PRMS model was forced with projections of daily precipitation, minimum daily temperature, and maximum daily temperature from 27 datasets for 1981-2099. These datasets include data generated from three GCMs and three statistical downscaling methods for three RCP scenarios: RCP 2.6, RCP 4.5, and RCP 8.5. Additional details on the datasets of climate projections used for this study are available in Wootten and others (2019). The projections are available via the USGS Geo Data Portal (Dixon and others, 2020). The downscaled climate projections used in this analysis are available at a $10-\mathrm{km}$ resolution. Area-weighted averaging was used to provide projected changes in daily precipitation, minimum daily temperature, and maximum daily temperature for each individual HRU in the PRMS model. 


\section{Representative Concentration Pathways (RCPs)}

The projections used in this analysis were created using three RCPs:

1. RCP 2.6 (van Vuuren and others, 2006, 2007)Radiative forcing on the climate system peaks at 2.6 watts per square meter $\left(\mathrm{W} \mathrm{m}^{-2}\right)$ before 2100 .

2. RCP 4.5 (Smith and Wigley, 2006; Clarke and others, 2007; Wise and others, 2009) - Radiative forcing on the climate system stabilizes at $4.0 \mathrm{~W} \mathrm{~m}^{-2}$ before 2100 .

3. RCP 8.5 (Rao and Riahi, 2006; Riahi and others, 2007) - Radiative forcing on the climate system reaches $8.5 \mathrm{~W} \mathrm{~m}^{-2}$ by 2100 .

The RCPs themselves were not developed with the intention that any one scenario is more likely than another. Rather, the RCPs represent a range of possible scenarios based on energy modeling efforts when they were developed (van Vuuren and others, 2011). RCP 2.6 represents a scenario for stabilization, RCP 4.5 is one scenario reflecting a mitigation, and RCP 8.5 is a high baseline scenario for emissions with no implemented climate policy. Because there is a range of options with respect to human action, these three RCPs (which span the range of available options for energy) are used in this analysis.

\section{Global Climate Models}

Each GCM uses each RCP as an input, and these results project the response of the climate system to the radiative forcing levels from each RCP. Projections were generated for historical (1981-2005) and future time periods (to 2099) by using three GCMs forced with each RCP and are available via the USGS Geo Data Portal (Dixon and others, 2020). While there are numerous GCMs to choose from in climate change studies, three GCMs from CMIP5 (Taylor and others, 2012) were used to create the projections used in this study. These three GCMs include the Community Climate System Model version 4 (CCSM4; Gent and others, 2011), the Model for Interdisciplinary Research on Climate version 5 (MIROC5; Watanabe and others, 2010), and the Max-Planck-Institute Earth System Model running on a low-resolution grid (MPIESM-LR; Giorgetta and others, 2013). The GCMs were selected because they have been shown to capture historical temperature and precipitation across the south-central United States and represent a range of climate sensitivity among the GCMs available in CMIP5 (Bertrand and McPherson, 2019; Wootten and others, 2020). Simulations of precipitation and temperature using the selected GCMs have been shown to have a smaller bias in comparison to other CMIP5 models while capturing the general spread of models by spanning a range of one standard deviation above and below the ensemble mean (Bertrand and McPherson, 2019).

\section{Statistical Downscaling Techniques}

The process of downscaling is used to translate the coarse-scale GCM output to the regional or local scale (Rummukainen, 2016; Tabari and others, 2016). Statistical downscaling is a type of downscaling that relies on using the GCM output for a historical period and historical observations to build statistical relationships. The statistical relationship built for the historical period is applied to the GCM output for the future time period to estimate the future "observations" at local/regional scales. There is not one single best approach to statistical downscaling, which results in multiple downscaling techniques that influence local/regional projections (Wootten and others, 2017). As such, the climate projections used in this analysis were created using three different statistical downscaling techniques. These three techniques include a delta method (DeltaSD), an equidistant quantile mapping method (EDQM), and a piecewise asynchronous regression method (PARM). More details on each of these methods are available in Wootten and others (2019). Because each downscaling method has different performance characteristics, the use of the range of techniques in this study allows us to acknowledge that downscaling methodological choices influence the value added by statistically downscaled projection data products. While the projections in this study also used multiple observation datasets for downscaling, this study uses only those created with Daymet to mimic the dataset used to calibrate the PRMS model.

\section{Streamflow Projections}

Simulated streamflow was generated from each GCM and downscaling method, giving a total of 9 scenarios per each RCP scenario for a total of 27 simulations. All model output was then parsed into four time periods: historical period, 1981-2005; future time period 1, 2022-47; future time period 2, 2048-73; and future time period 3, 2074-99. To compute potential climate-induced effects, hydrologic model simulations for the model historical period were subtracted from the model future time period. The ensemble members were averaged for each time period and RCP scenario for all streamflow segments (528 segments) represented in the Upper Rio Grande Basin PRMS model.

Streamflow values were analyzed for changes in the total volume of water (delta cumulative streamflow) and changes in the timing (delta streamflow timing) of runoff for (1) the entire basin, (2) each near-native subbasin, and (3) the Upper Rio Grande Basin main-stem gages on an annual and seasonal (snowmelt, monsoon) basis (table 1). This was done for each downscaled GCM, RCP, and future time period. The annual period includes all data for each year in a particular period, the snowmelt season includes all data between the beginning of February and the end of June, and the monsoon season includes all data between the beginning of July and the end of October. 
Table 1. Streamgages on the main stem of the Rio Grande and in near-native subbasins simulated by the Precipitation-Runoff Modeling System model for the Upper Rio Grande Basin, Colorado, New Mexico, and Texas.

[ID, identification; CO, Colorado; NM, New Mexico; TX, Texas]

\begin{tabular}{ll}
\hline \multicolumn{1}{c}{ Site ID } & \multicolumn{1}{c}{ Near-native subbasin gages } \\
\hline 08224500 & Kerber Creek above Little Kerber Creek near Villa Grove, CO \\
${ }^{1} 0628222$ & Pinos Creek near Del Norte, CO \\
${ }^{2} 08236000$ & Alamosa River above Terrace Reservoir, CO \\
08269000 & Rio Pueblo de Taos near Taos, NM \\
08275500 & Rio Grande del Rancho near Talpa, NM \\
08321500 & Jemez River below East Fork near Jemez Springs, NM \\
08334000 & Rio Puerco above Arroyo Chico near Guadalupe, NM \\
08340500 & Arroyo Chico near Guadalupe, NM \\
08354000 & Rio Salado near San Acacia, NM \\
\hline & \\
\hline 08220000 & Rio Grande near Del Norte, CO \\
08252000 & Rio Grande at Colorado-New Mexico State line \\
08313000 & Rio Grande at Otowi Bridge, NM \\
08358400 & Rio Grande floodway at San Marcial, NM \\
08370500 & Rio Grande at Fort Quitman, TX \\
\hline
\end{tabular}

${ }^{1}$ Former U.S. Geological Survey streamgage (08220500) added, now Colorado Division of Water Resources streamgage 0628222.

${ }^{2}$ Streamgage taken over by the Colorado Division of Water Resources.

Cumulative streamflow was calculated for all ensemble members of each RCP scenario for all years. The absolute and percent differences between the mean historical period value and each future year were then calculated to arrive at the change in streamflow volume (delta cumulative streamflow).

Center of mass dates were calculated for all ensemble members of each RCP scenario for all years. The center of mass date is the date in which 50 percent of the total yearly (or seasonal) volume of water has runoff. The absolute differences between the mean historical period value and each future year value were then calculated to arrive at delta streamflow timing. Center of mass dates were calculated instead of peak flow dates to remove the potential influence of large individual monsoonal storms that may skew the data.
Hydrographs of mean daily and cumulative streamflow were created for each near-native subbasin used in the calibration of the Upper Rio Grande Basin PRMS model and for five streamgage locations on the main stem of the Rio Grande in the Upper Rio Grande Basin to give an overview of potential streamflow change from varying RCPs and future time periods. Boxplots were also created to depict changes in the distribution and variability of streamflow by season, with absolute and percent differences at these sites for each future time period. Absolute and percent differences at these sites were then averaged for each future time period and are presented in tabular form (tables 2, 3). These data were also spatially plotted for the entire Upper Rio Grande Basin at each PRMS streamflow segment to visually represent spatial trends. 
Table 2. Projected changes in delta streamflow timing (days) between future time periods in the Precipitation-Runoff Modeling System model and representative concentration pathways on an annual and seasonal (snowmelt, monsoon) basis for streamgages on the main stem of the Rio Grande and in near-native subbasins in the Upper Rio Grande Basin, Colorado, New Mexico, and Texas.

[Negative values denote earlier streamflow and can also be seen in red. Positive values denote later streamflow and can also be seen in blue. RCP, representative concentration pathway (from van Vuuren and others, 2011; Intergovernmental Panel on Climate Change, 2019). The future time periods are as follows: future time period 1 between 2022 and 2047, future time period 2 between 2048 and 2073 , and future time period 3 between 2074 and 2099]

\begin{tabular}{|c|c|c|c|c|c|c|c|c|c|c|c|c|c|c|c|c|c|c|c|c|c|c|c|c|c|c|c|}
\hline & \multicolumn{9}{|c|}{ Snowmelt season } & \multicolumn{9}{|c|}{ Monsoon season } & \multicolumn{9}{|c|}{ Year } \\
\hline & \multicolumn{3}{|c|}{ RCP 2.6} & \multicolumn{3}{|c|}{ RCP 4.5} & \multicolumn{3}{|c|}{ RCP 8.5} & \multicolumn{3}{|c|}{ RCP 2.6} & \multicolumn{3}{|c|}{ RCP 4.5} & \multicolumn{3}{|c|}{ RCP 8.5} & \multicolumn{3}{|c|}{ RCP 2.6} & \multicolumn{3}{|c|}{ RCP 4.5} & \multicolumn{3}{|c|}{ RCP 8.5} \\
\hline & $22-47$ & 48-73 & 74-99 & $22-47$ & 48-73 & 74-99 & $22-47$ & 48-73 & 74-99 & $22-47$ & $48-73$ & 74-99 & $22-47$ & $48-73$ & 74-99 & $22-47$ & $48-73$ & 74-99 & $22-47$ & $48-73$ & 74-99 & $22-47$ & 48-73 & 74-99 & $22-47$ & $48-73$ & 74-99 \\
\hline \multicolumn{28}{|c|}{ Main-stem gages } \\
\hline Del Norte & -8 & -7 & -7 & -7 & -13 & -14 & -8 & -18 & -30 & 3 & 0 & 8 & 6 & 5 & 6 & 5 & 11 & 15 & -3 & -14 & -3 & -9 & -14 & -14 & -3 & -13 & -27 \\
\hline Stateline & -8 & -10 & -8 & -9 & -16 & -15 & -11 & -21 & -32 & -1 & -5 & 4 & 2 & 1 & 2 & 3 & 9 & 13 & 1 & -14 & -2 & -10 & -15 & -12 & -2 & -14 & -27 \\
\hline Otowi & -7 & -10 & -8 & -8 & -15 & -15 & -11 & -20 & -31 & -1 & -5 & 4 & 1 & 1 & 2 & 3 & 10 & 14 & 5 & -13 & 0 & -5 & -12 & -6 & 2 & -8 & -23 \\
\hline Marcial & -7 & -10 & -8 & -8 & -14 & -16 & -11 & -19 & -30 & 0 & -4 & 6 & 3 & 3 & 4 & 1 & 11 & 15 & 5 & -12 & 1 & -1 & -9 & -6 & 6 & -3 & -23 \\
\hline Quitman & -5 & -5 & -8 & -6 & -12 & -15 & -10 & -16 & -28 & 2 & -1 & 6 & 3 & 6 & 5 & 2 & 11 & 16 & 4 & -13 & 1 & -2 & -11 & -10 & 3 & -6 & -28 \\
\hline \multicolumn{28}{|c|}{ Near-native subbasin gages } \\
\hline Kerber & -4 & -6 & -5 & -8 & -11 & -13 & -9 & -15 & -26 & 3 & 0 & 4 & 5 & 3 & 6 & 3 & 6 & 6 & -6 & -15 & -12 & -16 & -23 & -21 & -8 & -17 & -29 \\
\hline Pinos & -5 & -2 & -5 & -7 & -11 & -11 & -5 & -17 & -30 & 3 & -1 & 8 & 2 & 4 & 4 & 4 & 8 & 9 & -2 & -9 & -3 & -12 & -16 & -19 & -8 & -20 & -37 \\
\hline Alamosa & -7 & -3 & -4 & -6 & -12 & -12 & -5 & -16 & -31 & 4 & 1 & 9 & 6 & 9 & 9 & 8 & 15 & 18 & -7 & -10 & -4 & -10 & -12 & -13 & -6 & -17 & -26 \\
\hline Pueblo & -2 & -6 & -4 & -2 & -10 & -10 & -7 & -15 & -20 & 2 & 1 & 6 & 5 & 4 & 4 & 4 & 8 & 12 & 2 & -7 & -3 & 10 & -12 & -6 & -4 & -9 & -16 \\
\hline Rancho & -8 & -10 & -9 & -7 & -7 & -10 & -7 & -12 & -17 & 3 & 1 & 3 & 3 & 5 & 7 & 5 & 7 & 9 & 0 & -13 & -11 & -4 & -3 & -6 & 4 & -7 & -9 \\
\hline Jemez & -1 & -5 & -7 & -8 & -9 & -17 & -8 & -9 & -17 & 1 & 0 & 3 & 4 & 1 & 5 & -2 & 3 & 10 & 22 & -19 & -6 & 19 & -10 & 5 & 35 & 6 & 4 \\
\hline Puerco & -9 & -16 & -13 & -12 & -10 & -15 & -12 & -14 & -22 & 2 & 1 & 2 & -3 & 0 & 2 & -2 & -3 & 0 & -5 & -17 & -4 & -2 & -17 & -8 & 2 & 2 & -6 \\
\hline Chico & -10 & -17 & -12 & -10 & -6 & -8 & 1 & -4 & -17 & 0 & 2 & 2 & -2 & -4 & -2 & 3 & 1 & 6 & -2 & -13 & -4 & 9 & -4 & 3 & 5 & 5 & 5 \\
\hline Salado & -25 & -25 & -24 & -26 & -14 & -28 & -10 & -20 & -33 & -1 & 7 & 5 & 4 & 3 & 7 & 1 & 15 & 17 & -8 & -3 & -2 & -2 & -5 & -4 & -5 & -6 & -7 \\
\hline
\end{tabular}


Table 3. Projected changes in delta streamflow volume (percent) between future time periods in the Precipitation-Runoff Modeling System model and representative concentration pathways on an annual and seasonal (snowmelt, monsoon) basis for streamgages on the main stem of the Rio Grande and in near-native subbasins in the Upper Rio Grande Basin, Colorado, New Mexico, and Texas.

[Negative values denote less streamflow and can also be seen in red. Positive values denote more streamflow and can also be seen in blue. RCP, representative concentration pathway (from van Vuuren and others, 2011; Intergovernmental Panel on Climate Change, 2019). The future time periods are as follows: future time period 1 between 2022 and 2047, future time period 2 between 2048 and 2073 , and future time period 3 between 2074 and 2099]

\begin{tabular}{|c|c|c|c|c|c|c|c|c|c|c|c|c|c|c|c|c|c|c|c|c|c|c|c|c|c|c|c|}
\hline & \multicolumn{9}{|c|}{ Snowmelt season } & \multicolumn{9}{|c|}{ Monsoon season } & \multicolumn{9}{|c|}{ Year } \\
\hline & \multicolumn{3}{|c|}{ RCP 2.6} & \multicolumn{3}{|c|}{ RCP 4.5} & \multicolumn{3}{|c|}{ RCP 8.5} & \multicolumn{3}{|c|}{ RCP 2.6} & \multicolumn{3}{|c|}{ RCP 4.5} & \multicolumn{3}{|c|}{ RCP 8.5} & \multicolumn{3}{|c|}{ RCP 2.6} & \multicolumn{3}{|c|}{ RCP 4.5} & \multicolumn{3}{|c|}{ RCP 8.5} \\
\hline & $22-47$ & 48-73 & 74-99 & $22-47$ & $48-73$ & 74-99 & $22-47$ & 48-73 & 74-99 & $22-47$ & $48-73$ & 74-99 & $22-47$ & $48-73$ & 74-99 & $22-47$ & 48-73 & 74-99 & $22-47$ & 48-73 & 74-99 & $22-47$ & 48-73 & 74-99 & $22-47$ & $48-73$ & 74-99 \\
\hline \multicolumn{28}{|c|}{ Main-stem gages } \\
\hline Del Norte & 17 & 16 & 20 & 31 & 51 & 23 & 24 & 24 & 52 & -4 & -23 & -7 & -9 & -1 & -14 & -3 & -9 & -23 & 14 & 3 & 14 & 21 & 39 & 16 & 14 & 13 & 28 \\
\hline Stateline & 7 & 13 & 14 & 19 & 36 & 11 & 14 & 12 & 36 & -2 & -21 & -5 & -11 & 1 & -14 & -1 & -7 & -20 & 10 & 5 & 14 & 16 & 33 & 11 & 9 & 5 & 18 \\
\hline Otowi & -7 & 3 & 4 & 6 & 24 & -2 & 2 & -2 & 20 & -3 & -22 & -5 & -16 & -5 & -20 & -3 & -6 & -23 & -2 & -5 & 4 & 5 & 20 & 0 & -1 & -6 & 4 \\
\hline Marcial & -4 & 5 & 7 & 8 & 29 & 4 & -1 & -4 & 18 & -8 & -27 & -11 & -14 & -4 & -19 & -7 & -10 & -30 & -5 & -11 & 0 & 0 & 15 & -1 & -1 & -7 & 0 \\
\hline Quitman & -1 & 7 & 14 & 12 & 36 & 15 & 9 & 11 & 40 & -18 & -33 & -20 & -19 & -11 & -27 & -15 & -23 & -41 & -12 & -17 & -6 & -6 & 8 & -7 & -2 & -8 & -2 \\
\hline \multicolumn{28}{|c|}{ Near-native subbasin gages } \\
\hline Kerber & 12 & 15 & 29 & 23 & 47 & 6 & 14 & 1 & 35 & -2 & -15 & -3 & -9 & -1 & -29 & -9 & -25 & -35 & 2 & -1 & 12 & 6 & 26 & -10 & 9 & -5 & 16 \\
\hline Pinos & 10 & 15 & 13 & 27 & 40 & 25 & 21 & 22 & 60 & -4 & -4 & 4 & 2 & 7 & -4 & 5 & -5 & -7 & 3 & 2 & 10 & 16 & 28 & 14 & 10 & 8 & 33 \\
\hline Alamosa & 9 & 11 & 9 & 17 & 30 & 16 & 6 & 8 & 26 & -16 & -26 & -9 & -18 & -7 & -16 & -12 & -22 & -25 & -1 & -8 & 0 & 3 & 19 & 6 & 2 & 2 & 20 \\
\hline Pueblo & -23 & 9 & 6 & -1 & 9 & -25 & -16 & -33 & -27 & -17 & -2 & 1 & 4 & 7 & -25 & -19 & -34 & -37 & -17 & 10 & 12 & 8 & 14 & -18 & -7 & -29 & -22 \\
\hline Rancho & -5 & 30 & 42 & 41 & 38 & -14 & 9 & -24 & -5 & -13 & 4 & 3 & 5 & 13 & -15 & -9 & -17 & -17 & -8 & 18 & 25 & 26 & 26 & -13 & 6 & -21 & -7 \\
\hline Jemez & 9 & 81 & 80 & 56 & 90 & 68 & 63 & 45 & 74 & -6 & -25 & -7 & -10 & -5 & -9 & -11 & -8 & -22 & 8 & 38 & 49 & 41 & 52 & 63 & 58 & 32 & 48 \\
\hline Puerco & -18 & -17 & -13 & -13 & 14 & 9 & -25 & -29 & -23 & -7 & -33 & 2 & -13 & -7 & -15 & -11 & 4 & -15 & -7 & -23 & -2 & -7 & 6 & 16 & -6 & -10 & -12 \\
\hline Chico & -21 & -10 & -20 & -13 & 7 & -23 & -9 & -11 & -17 & -1 & -25 & -7 & -12 & -1 & 0 & -13 & -2 & -20 & -6 & -18 & -10 & -10 & 3 & 0 & -10 & -6 & -17 \\
\hline Salado & 56 & 1 & 131 & 47 & 124 & 349 & 50 & 82 & 139 & 58 & 11 & 38 & 95 & 103 & 42 & 7 & 55 & -45 & 20 & -20 & 29 & 21 & 35 & 57 & 7 & 44 & -12 \\
\hline
\end{tabular}




\section{Results}

\section{Model Validation}

The calibrated model performed well at all near-native subbasin gages. Monthly streamflow values from the initial NHM-PRMS model and the calibrated model were compared against streamgage data in the near-native subbasins, and summary statistics were calculated (table 4). The initial NHMPRMS model values demonstrated a poor fit for all near-native subbasins. The annual volume bias was between about -70 and 900 percent. Calibration of the model resulted in substantial improvements in monthly streamflow simulations from the initial NHM-PRMS parameterization. Generally, the calibrated model performed better in the northerly, snowmelt-dominated subbasins than in the central and southern monsoon-dominated subbasins that deliver little cumulative streamflow volume to the Upper Rio Grande Basin. This difference is due to difficulty associated with calibrating subbasins with periods of zero flow (that is, flow intermittency) and rapidly changing (that is, "flashy") streamflows (table 4).

The parameter distribution method was validated by a stepwise removal of near-native subbasins in the parameter distribution function. Estimated streamflow from the nearnative subbasins was then compared to the measured streamflow at streamgages, and summary statistics were calculated. Calibrated model performance was significantly improved over the initial NHM and displayed satisfactory to very good percent bias based on guidelines provided by Moriasi and others (2007). Full calibration and validation results are available in Chavarria and others (2020a). These results demonstrate that the PRMS model calibration and development were successful and that the integration of local basin characteristics vastly improved model simulations over that of the NHM and is appropriate for simulation of near-native conditions throughout the Upper Rio Grande Basin. As shown in figure 2, the difference between simulated and measured streamflow is from anthropogenic effects such as diversions and reservoirs.

\section{Downscaled Climate Projections}

Each of the three GCMs has a wet bias in annual total rainfall in the region. The various downscaling techniques correct the bias associated with the GCMs, resulting in small errors in annual total precipitation across the Rio Grande Basin. The GCMs also have a known tendency to overestimate the number of days with rainfall, particularly the frequency of light rain events (commonly referred to as a "drizzle bias"; Stephens and others, 2010; Pendergrass and Hartmann, 2014). The drizzle bias is reflected in the GCM error with respect to the number of days with precipitation. This bias in the GCMs is also one of the aspects that the statistical downscaling corrects, dramatically reducing the error with respect to the variables in the downscaled projections. Finally, there is also a general known tendency for GCMs to be undervariable with respect to daily precipitation, resulting in a tendency to underestimate extremes of rainfall (Pendergrass and Hartmann, 2014). However, for the Upper Rio Grande Basin, the GCMs tend to overestimate precipitation as a result of a tendency for the GCMs used in this study to overestimate precipitation extremes. This known bias of the GCMs is also corrected by each of the three statistical downscaling techniques used in this study.

It is relevant to address some of the distinct differences between the downscaling techniques and the potential influences on projections of precipitation. Many of these differences are discussed in depth by Wootten and others (2020) and are summarized here. The three downscaling techniques represent two different styles for incorporating the results of the GCMs at smaller scales. The DeltaSD applies the change signal from the monthly precipitation in the GCM to the

Table 4. Monthly model validation statistics comparing the initial National Hydrologic Model and the calibrated model.

[NSE, Nash Sutcliffe efficiency; R², coefficient of determination; bias (\%), percent bias; NHM, National Hydrologic Model; cal., calibrated; CO, Colorado; NM, New Mexico]

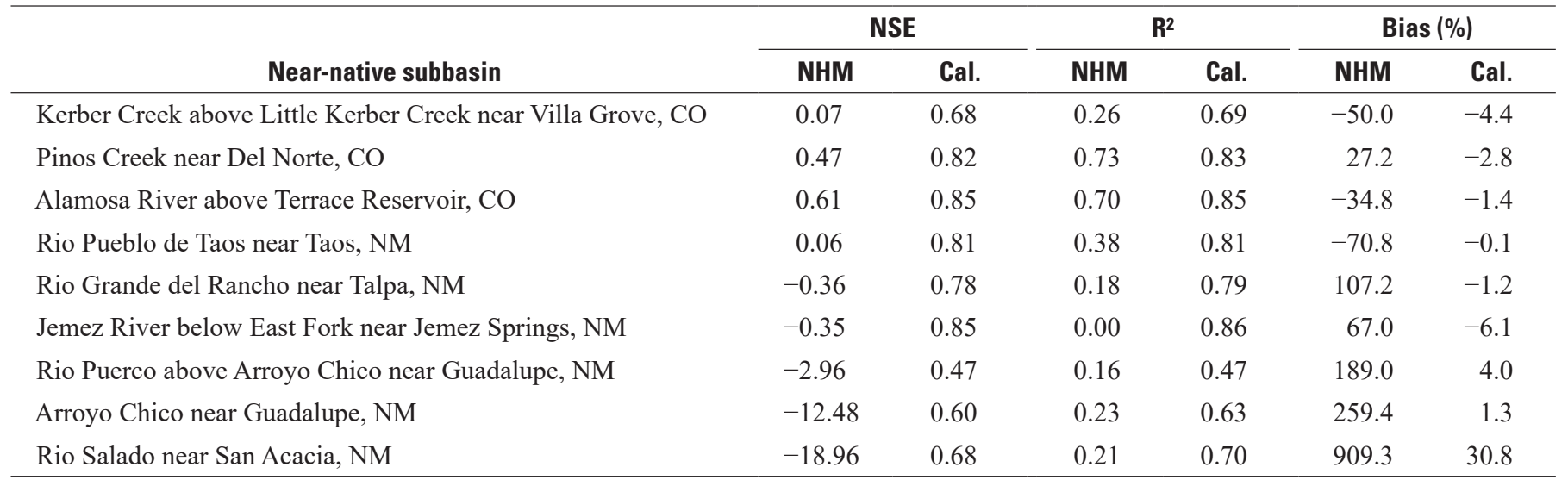



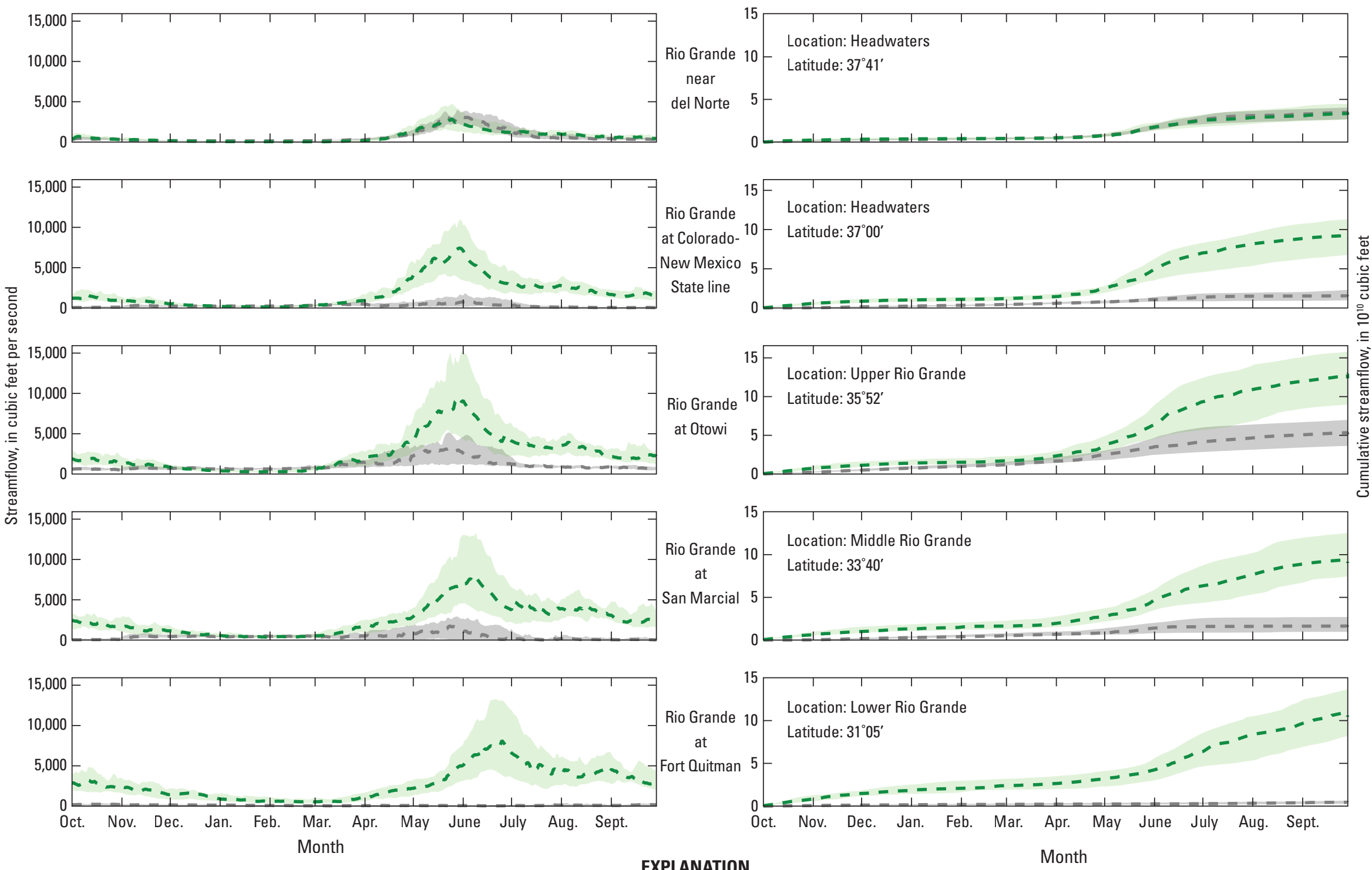

\section{EXPLANATION}

Month

25-75\% quantile range , ' Median Calibrated model (simulated natural streamflow) - Streamgage (measured streamflow)

Figure 2. Comparison of the simulated streamflow representing naturalized mean monthly flow to observed streamflow at streamgages on the main stem of the Rio Grande between 1980 and 2015 in the Upper Rio Grande Basin, Colorado, New Mexico, and Texas. Graphs are ordered from upstream (top) to downstream (bottom); see table 1 for streamgage information; \%, percent. 
Daymet training data. As such, the DeltaSD will always have the best historical performance, as it reflects only the observations themselves. However, the future projections with the DeltaSD apply monthly projected changes in precipitation and temperature to the Daymet observations. Therefore, any GCM downscaled with DeltaSD will retain the same sequence of weather events that exists in Daymet, and the statistical distribution of precipitation will not change significantly. As such, it is expected that the downscaled projections created with Daymet will not project significant changes in precipitation extremes or the frequency of rain events but will capture known seasonal cycles of rainfall in the region more so than will the projections created with the other two downscaling techniques.

The remaining two downscaling techniques (EDQM and PARM) preserve the change from the GCM at all quantiles of the distribution. Therefore, the GCMs downscaled with EDQM and PARM will preserve seasonal and annual changes from the GCM and reflect GCM projected changes to the frequency and intensity of daily temperature and precipitation events. However, while the DeltaSD retains the sequence of weather events in Daymet, the EDQM and PARM retain the sequence of weather events in the GCM used for downscaling. These differences in turn would affect changes in the timing and frequency of dry and wet spells in the Upper Rio Grande Basin.

Therefore, the three downscaling techniques used in this study reflect two different ways to treat the distribution and the sequence of daily precipitation and temperature. These differences are relevant to the results of the PRMS simulations because the daily precipitation and temperature output of the projections is used by PRMS to determine future streamflow in the Upper Rio Grande Basin. Therefore, it is anticipated that the different downscaling techniques will affect the variability of streamflow projections from PRMS alongside the differences between GCMs and RCPs.

\section{Projected Change in Temperature and Precipitation}

The downscaled climate projections show consistent changes in temperature across the Upper Rio Grande Basin. The annual average high temperature is projected to increase by as much as $3.76^{\circ} \mathrm{F}$ on average under RCP 8.5 in future time period $1(2022-47)$, up to $6.23^{\circ} \mathrm{F}$ on average under RCP 8.5 in future time period 2 (2048-73), and up to $9.33^{\circ} \mathrm{F}$ on average under RCP 8.5 in future time period 3 (2074-99; fig. 3). The annual average low temperatures are projected to increase by a similar amount compared to the historical period. These projected increases in temperatures would increase the rates of evapotranspiration in the region and make drought more likely.
The monsoon (July-October) and snowmelt (FebruaryJune) seasons are critical times for streamflow and precipitation in the Upper Rio Grande Basin for supporting ecosystems, agriculture, and water resources for communities. The average projected change in total precipitation during the monsoon and snowmelt seasons suggests that, in general, precipitation will decrease during both seasons across the Upper Rio Grande Basin, with the largest decreases under RCP 8.5 in future time period 3 (2074-99, table 5). However, it should be noted that there is substantial spread in the projections across the model domain. During the future time period 1 in the monsoon season, there is a range of projected changes, from a decrease in rainfall to an increase in rainfall across the Upper Rio Grande Basin (fig. 4). However, one consistent feature is that rainfall near the headwaters of the Rio Grande is projected to increase or have almost no change in monsoon season total rainfall in the future time period 1 (fig. 4). During the future time period 2 , the projected changes in monsoon rainfall range from increasing rainfall across the domain to a decrease in rainfall (fig. 4). Finally, during the future time period 3, all of the projections suggest that monsoon rainfall will not change or will slightly increase in the northwest part of the domain, including the Rio Grande headwaters (fig. 4).

Projected changes to snowmelt season precipitation in comparison to the historical period also have considerable spread between individual downscaled climate projections. During the future time period 1, many projections suggest no change to a slight decrease in snowmelt season rainfall, with some potential increases projected in the headwaters (fig. 5). During the future time period 2, the projections generally suggest that snowmelt season rainfall either will not change or will slightly increase in the Rio Grande headwaters and either will not change substantially or will decrease in the rest of the basin (fig. 5). Finally, for the future time period 3, there is considerable spread for the projected change in snowmelt season rainfall by emissions scenario. Under RCP 2.6, the snowmelt season rainfall is projected to have no change or to increase, potentially with substantial increases in the Rio Grande headwaters (fig. 5). Under the remaining scenarios, the headwaters are projected to have little to no change in snowmelt season rainfall with projected decreases in snowmelt season rainfall across much of the Upper Rio Grande Basin (fig. 5).

The projected changes in air temperature are an important consideration with regards to changes in precipitation and thus streamflow. The projected increase in temperatures would occur during all seasons, which would increase the rate of evapotranspiration. These changes would increase the potential for drought conditions, thereby decreasing streamflow. The projected increase in temperature also would result in decreasing precipitation falling as snow in the Rio Grande headwaters. 

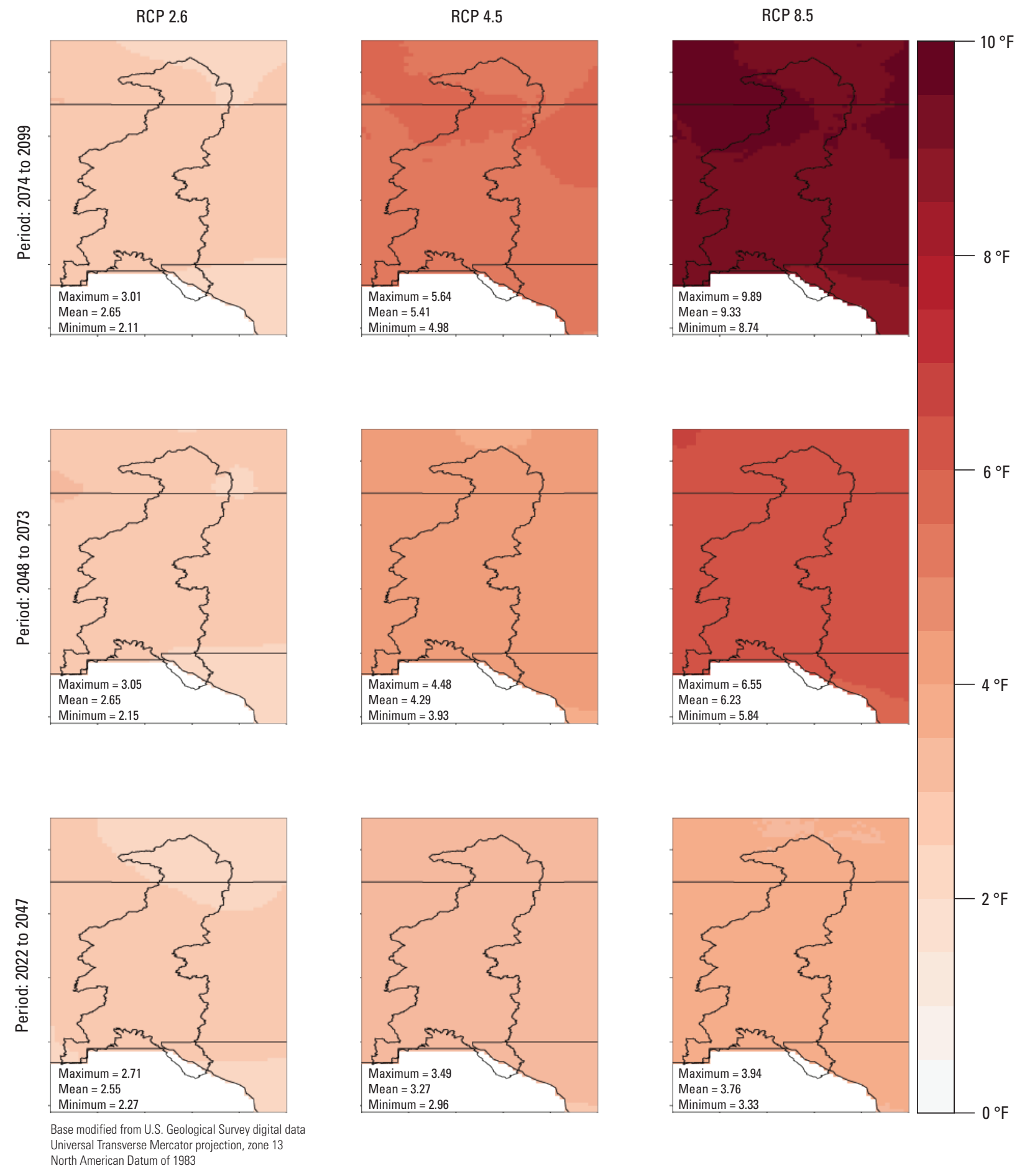

Figure 3. Projected changes in annual average high temperature from the ensemble mean of all general circulation models using representative concentration pathways (RCPs) 2.6, 4.5, and 8.5 (from van Vuuren and others, 2011; Intergovernmental Panel on Climate Change, 2019) and downscaling methods. The black-outlined polygon is the exact model domain shown in figure 1. ${ }^{\circ}$, degree Fahrenheit. 
RCP 26
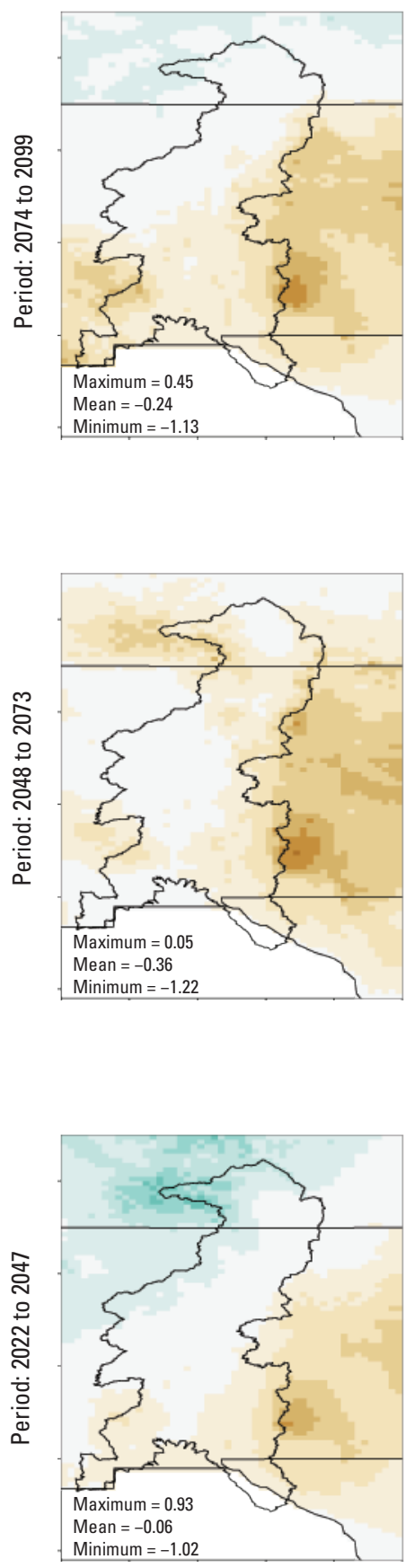

Base modified from US. Geological Survey digital data Universal Transverse Mercator projection, zone 13 North American Datum of 1983
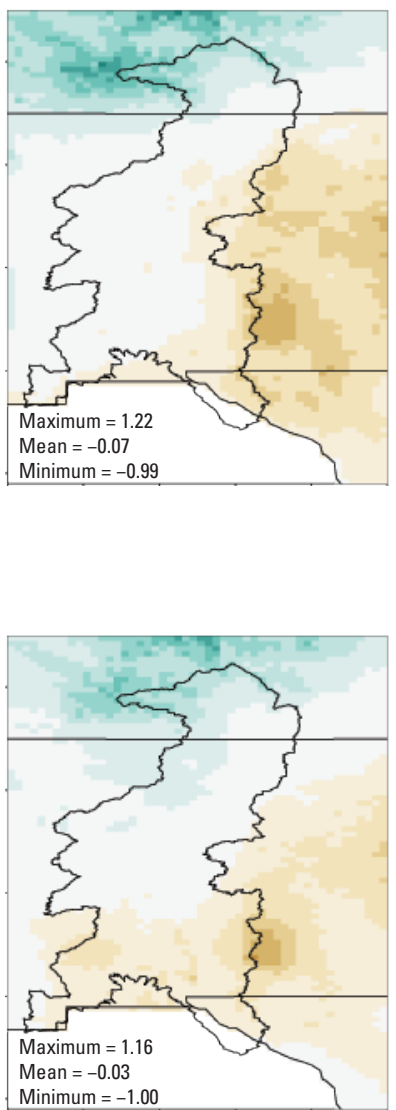

RCP 85
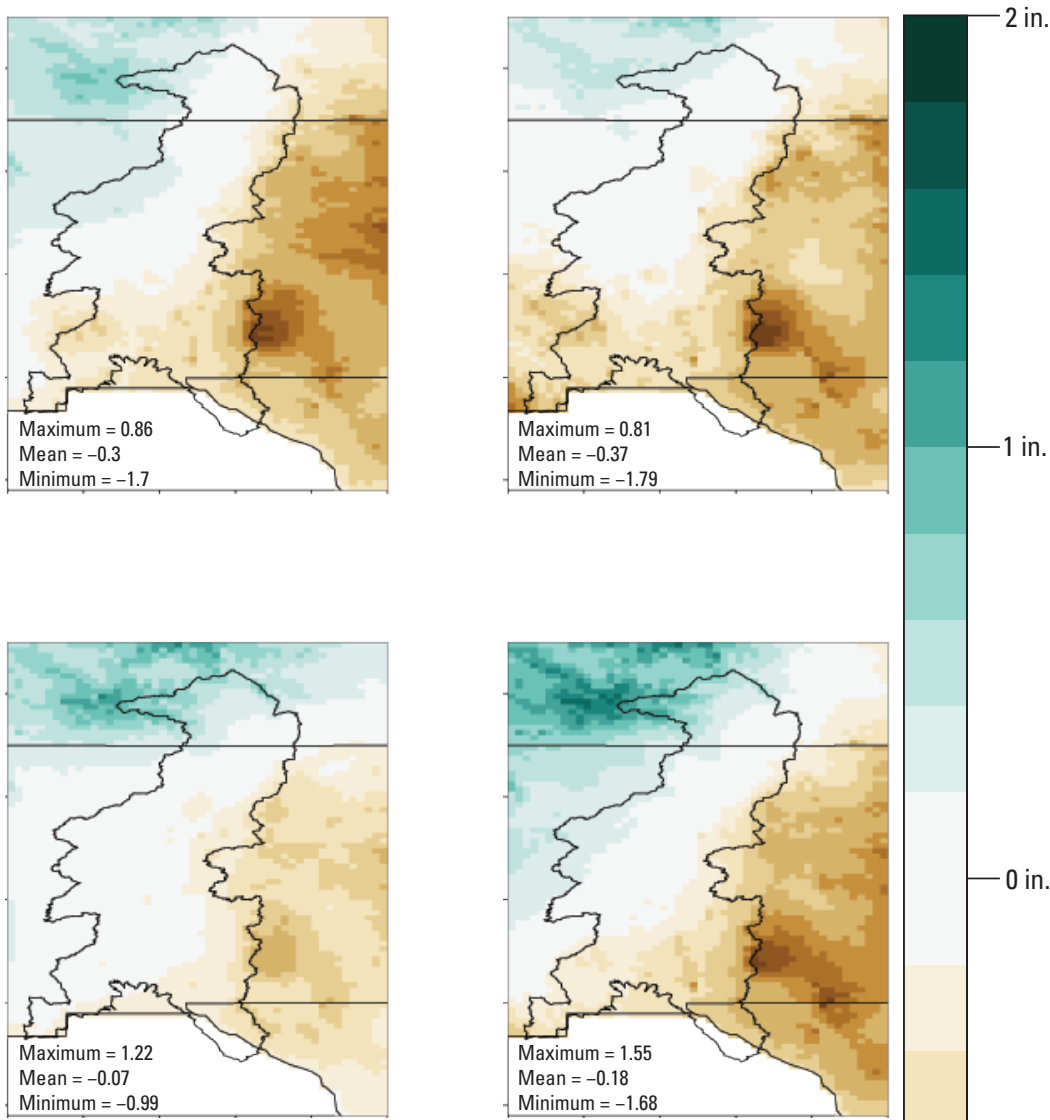

0 in

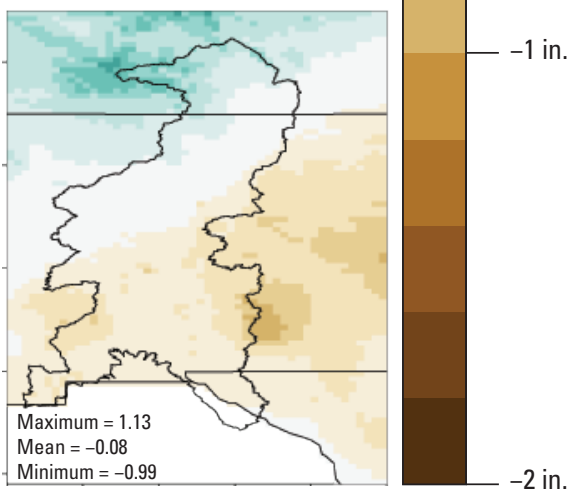

Figure 4. Projected changes in precipitation during monsoon season (July-0ctober) from the ensemble mean of all general circulation models using representative concentration pathways (RCPs) 2.6, 4.5, and 8.5 (from van Vuuren and others, 2011; Intergovernmental Panel on Climate Change, 2019) and downscaling methods. The black-outlined polygon is the exact model domain shown in figure 1. in., inch. 

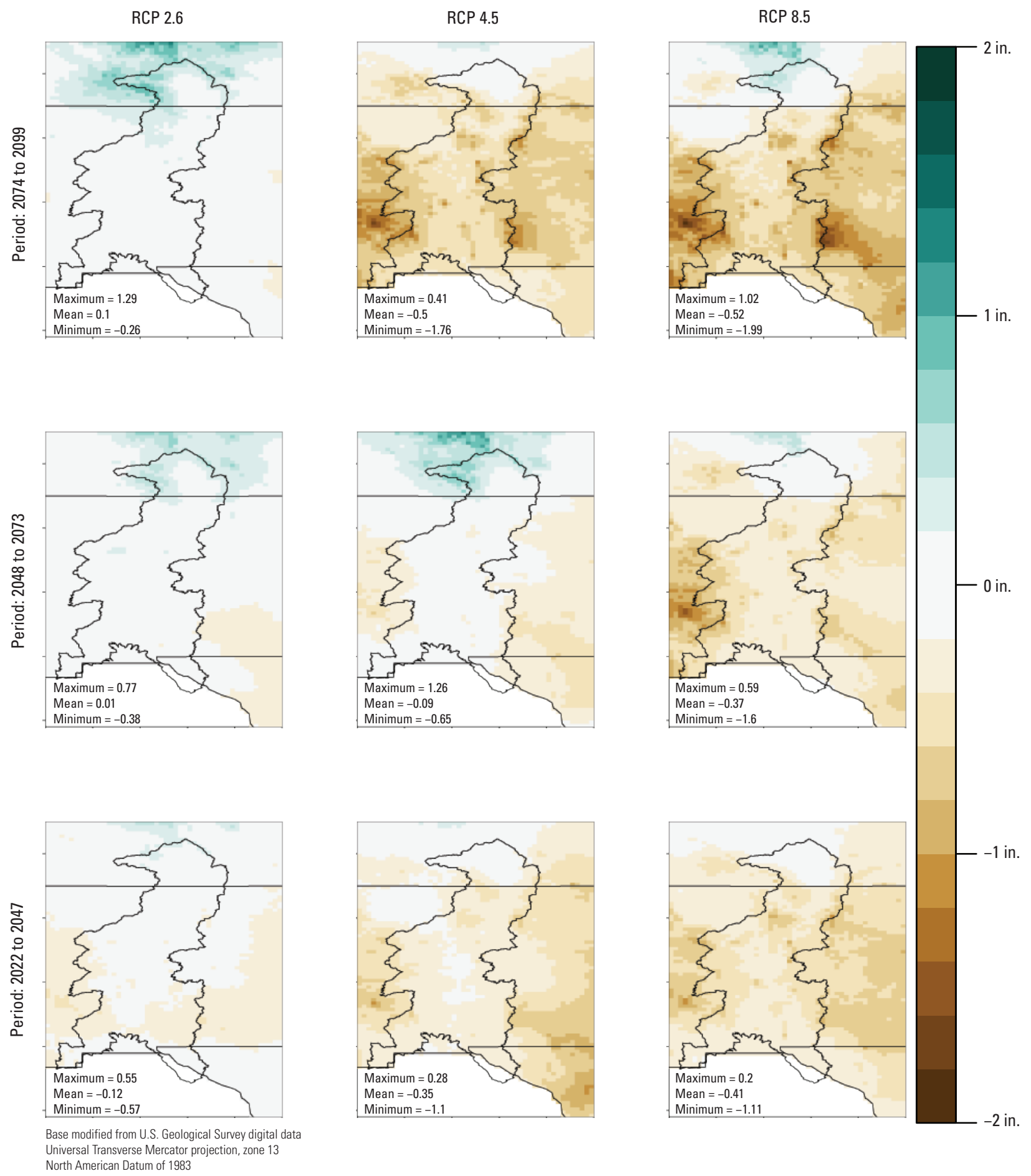

Figure 5. Projected changes in precipitation during snowmelt season (February-June) from the ensemble mean of all general circulation models using representative concentration pathways (RCPs) 2.6, 4.5, and 8.5 (from van Vuuren and others, 2011; Intergovernmental Panel on Climate Change, 2019) and downscaling methods. The black-outlined polygon is the exact model domain shown in figure 1. in., inch. 
Table 5. Average projected changes in total precipitation (in inches) during the monsoon and snowmelt seasons across the Upper Rio Grande Basin for each future time period by representative concentration pathways 2.6, 4.5, and 8.5 (from van Vuuren and others, 2011 ; Intergovernmental Panel on Climate Change, 2019) and downscaling methods.

[RCP, representative concentration pathway]

\begin{tabular}{|c|c|c|c|c|c|c|}
\hline \multirow[b]{2}{*}{ Scenario } & \multicolumn{3}{|c|}{ Monsoon } & \multicolumn{3}{|c|}{ Snowmelt } \\
\hline & (2022-47) & (2048-73) & (2074-99) & (2022-47) & $(2048-73)$ & (2074-99) \\
\hline RCP 2.6 & -0.06 & -0.36 & -0.24 & -0.12 & 0.01 & 0.09 \\
\hline RCP 8.5 & -0.09 & -0.18 & -0.37 & -0.41 & -0.37 & -0.52 \\
\hline
\end{tabular}

\section{Projected Change in Streamflow at Streamgage Locations in the Upper Rio Grande Basin}

Simulated hydrographs of streamflow and cumulative streamflow volume for streamgages on the Rio Grande main stem (fig. 6) and outflow streamgages in near-native subbasins (figs. 7, 8) show changes from the historical period (1981-2015) in the magnitude and timing of streamflow for all future time periods and RCP scenarios. In general, changes in streamflow timing at all Rio Grande main-stem gages showed shifts in timing of peak flow toward earlier in the year, whereas changes in streamflow timing at gages in near-native subbasins varied by location in the basin. Mean changes in streamflow timing at near-native subbasins Rio Puerco, Arroyo Chico, and Rio Salado in the middle to southern part of the basin showed relatively small shifts in streamflow timing toward later in the year.

Changes in streamflow volume along the Rio Grande main stem showed a similar trend for all RCPs and time periods where streamflow volume increases at headwater gages (Del Norte and Stateline) and decreases at all other gages below the headwaters. The largest percent differences in streamflow volume between the historical period and the future time periods were not found in the main-stem gages but rather in the gages in the near-native subbasins. Streamflow volume in the headwater gages in the near-native subbasins (Kerber Creek, Pinos Creek, and Alamosa River) generally increased for all RCP scenarios. However, notable decreases in projected streamflow volume as compared to historical values were seen in the Upper Rio Grande in the Sangre de Cristo Mountains at the Rio Pueblo de Taos and Rio Grande del Rancho gages in the near-native subbasins. The Jemez River subbasin reacted differently than did other near-native subbasins to RCP scenarios in that streamflow volume increased in later future time periods under the RCP 2.6 and 4.5 scenarios and in earlier time periods in the RCP 8.5 scenario. This is contrasted by streamflow volume in near-native subbasins in the southern part of the basin (Rio Puerco, Arroyo Chico, Rio Salado), which generally decreased under all RCP scenarios.
Because the drivers of streamflow change spatially in the basin, it is important to look at changes in projected streamflow both seasonally and by region in order to determine how streamflow may be affected under different emission scenarios. The following sections describe annual and seasonal changes in streamflow volume and timing in the basin regionally: the headwaters region, the Upper Rio Grande region, and the combined Middle and Lower Rio Grande regions. In the following sections, simulated streamflows are parsed into yearly time series and binned into seasonal statistics for quantitative comparisons of changing streamflow volume and timing. At most sites reported herein, the greatest changes occur under the high radiative forcing scenario (RCP 8.5).

\section{Headwaters Region}

The headwaters region of the Upper Rio Grande Basin includes three near-native subbasin gages at Kerber Creek, Pinos Creek, and the Alamosa River and two main-stem gages at Del Norte and Stateline (fig. 1; table 1). Streamflow in this region is primarily generated by the melting of seasonal snowpack with peak streamflow historically occurring in June (figs. 6-8). Monsoons contribute a less substantial portion to the overall water balance of the headwaters region as compared to the other regions.

\section{Projected Changes in Streamflow Volume}

Main-stem streamgages on the Rio Grande in the headwaters region (Del Norte and Stateline) displayed an overall positive mean change in annual and snowmelt season streamflow volume with decreases in streamflow volume in the monsoon season (table 3). The future change in streamflow volume was primarily dictated by changes during the snowmelt season. The overall positive change in streamflow in the region was due to shifts in the timing of streamflow, where more of the cumulative volume is concentrated in the snowmelt season, whereas historically a part of that streamflow would have occurred during the early part of the monsoon season (July). In comparison to the monsoon season, there was greater variability in changes in streamflow volume during the snowmelt season (figs. 9, 10). 

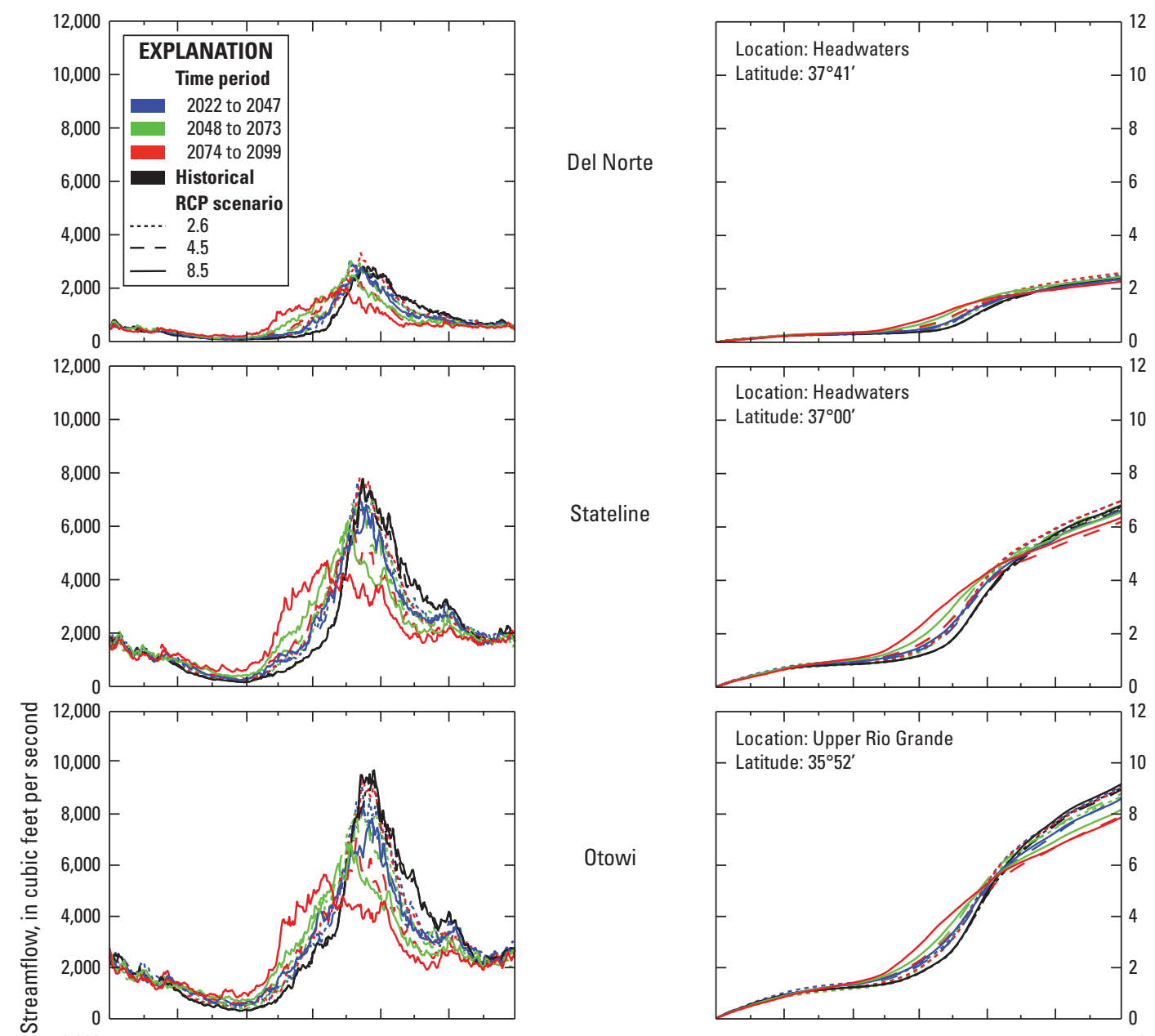

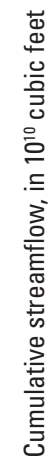
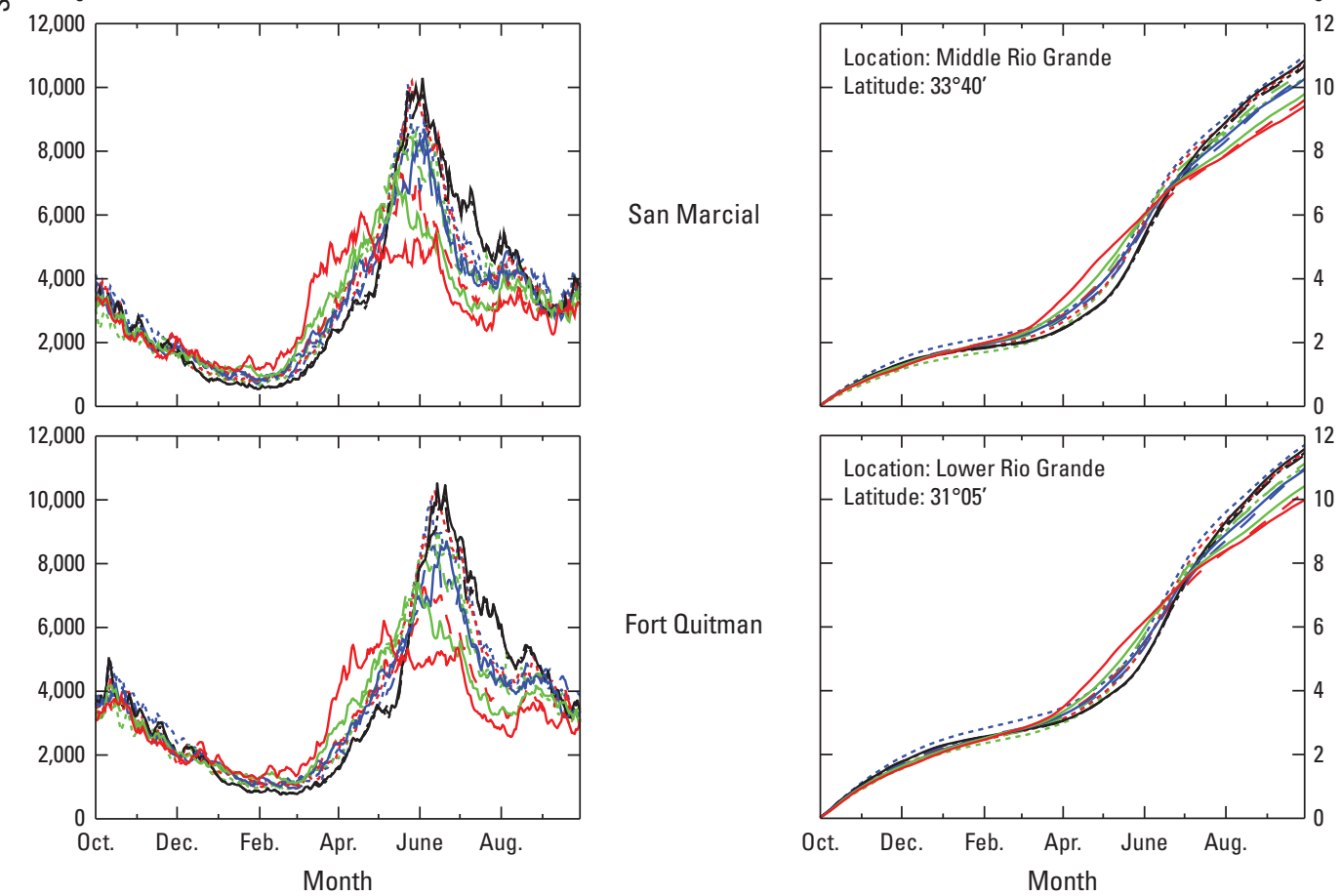

Figure 6. Simulated hydrographs of main-stem gages from upstream to downstream using the ensemble mean of all general circulation models and downscaling methods using representative concentration pathways (RCPs) 2.6, 4.5, and 8.5 (from van Vuuren and others, 2011; Intergovernmental Panel on Climate Change, 2019). See table 1 for streamgage information. 

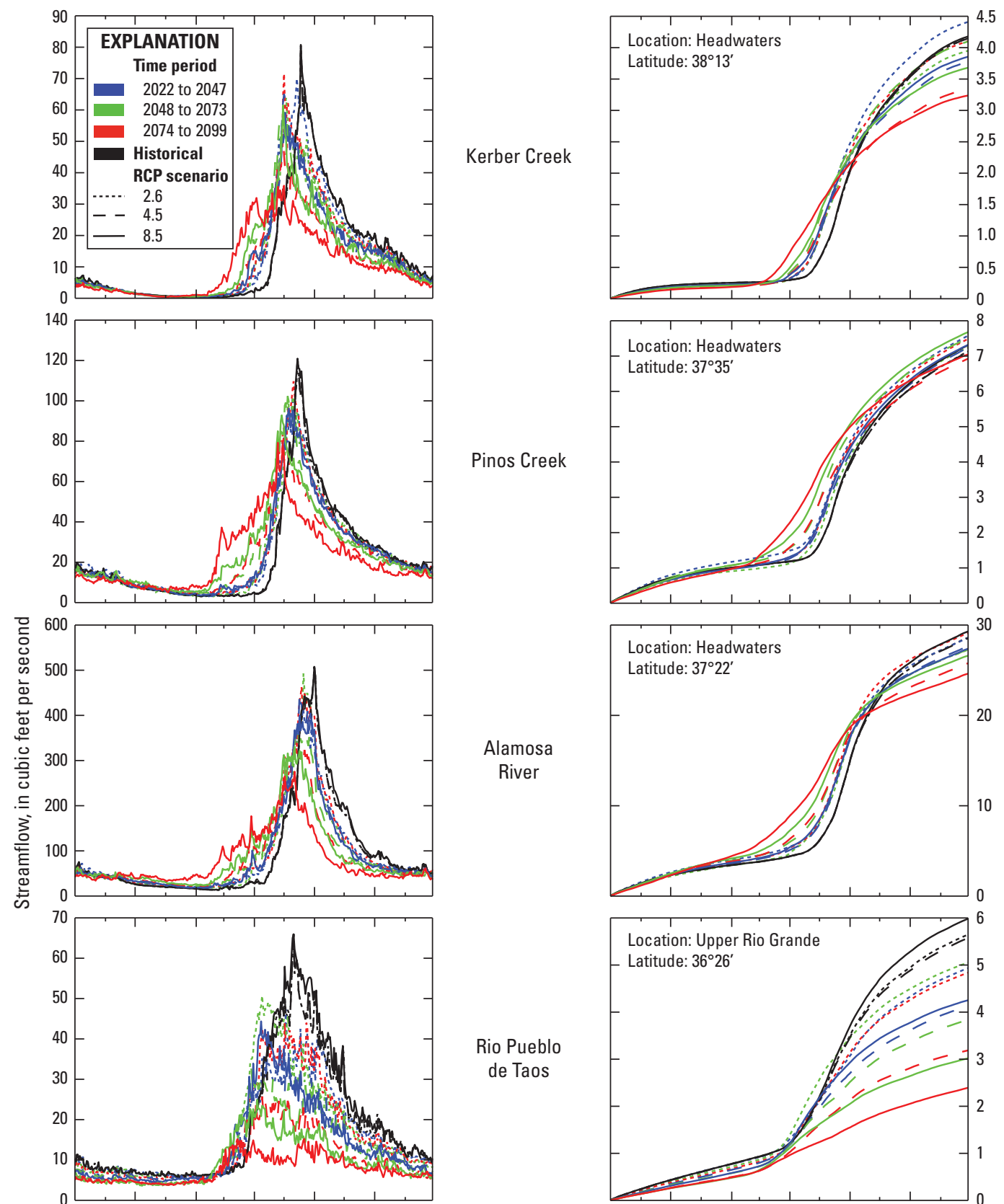

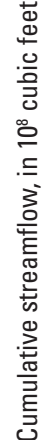
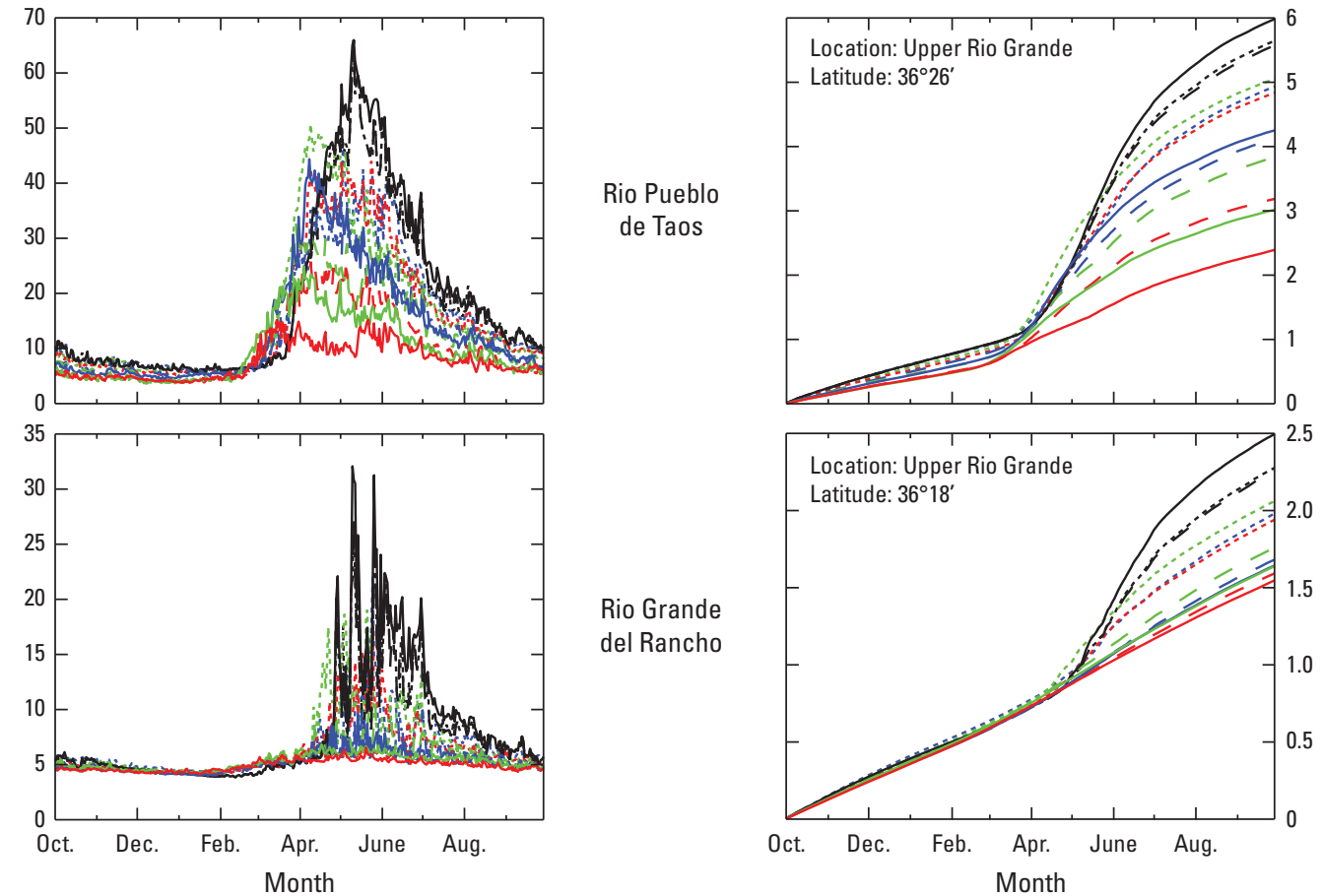

Figure 7. Simulated hydrographs of near-native gages from upstream to downstream using the ensemble mean of all general circulation models and downscaling methods using representative concentration pathways (RCPs) 2.6, 4.5, and 8.5 (from van Vuuren and others, 2011; Intergovernmental Panel on Climate Change, 2019). See table 1 for streamgage information. 

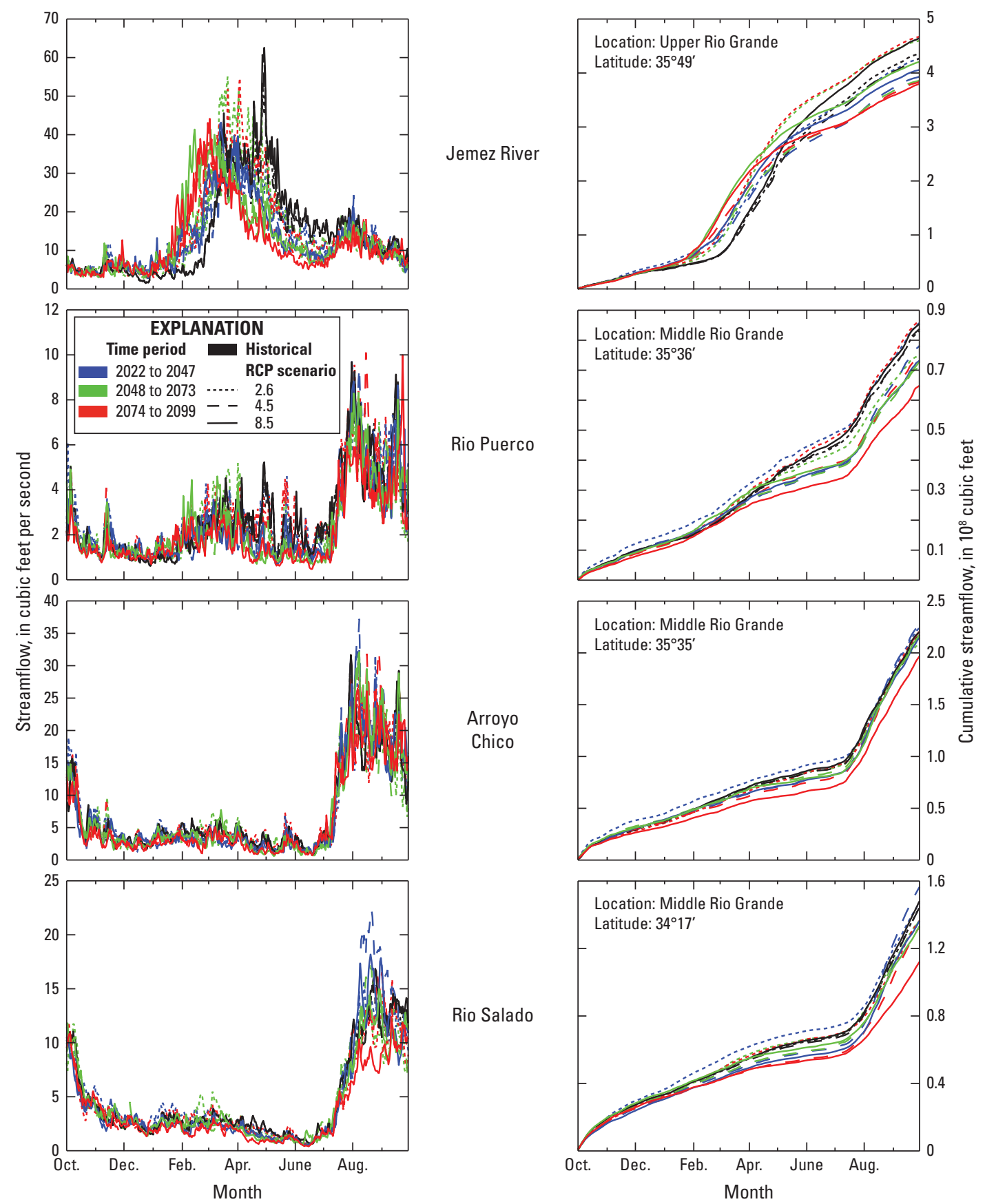

Figure 8. Simulated hydrographs of near-native gages from upstream to downstream using the ensemble mean of all general circulation models and downscaling methods using representative concentration pathways (RCPs) 2.6, 4.5, and 8.5 (from van Vuuren and others, 2011; Intergovernmental Panel on Climate Change, 2019). See table 1 for streamgage information.

For RCP 8.5 at the latest future time period, mean streamflow volume during snowmelt season increased 26-60 percent at the near-native subbasin gages and 36-52 percent at the main-stem gages in the headwaters region (figs. 9, 10; table 3). These values were partially offset by reductions in streamflow volume during the monsoon season. For RCP 8.5 at the latest future time period, mean streamflow volume during monsoon season decreased 7-35 percent at the near-native subbasin gages and 20-23 percent at the main-stem gages (figs. 9, 10; table 3 ). This led to increases in mean yearly cumulative volume at all near-native subbasin and main-stem gages that ranged between a 16-33 percent increase at the subbasin gages and an 18-28 percent increase on the main-stem gages. However, note the large interquartile range of yearly values and data skew in cumulative yearly volume differences during the snowmelt season in figures 9 and 10 . These results display a large data variance in cumulative volume changes for all future time periods and RCP scenarios that is not captured from the mean value alone. 

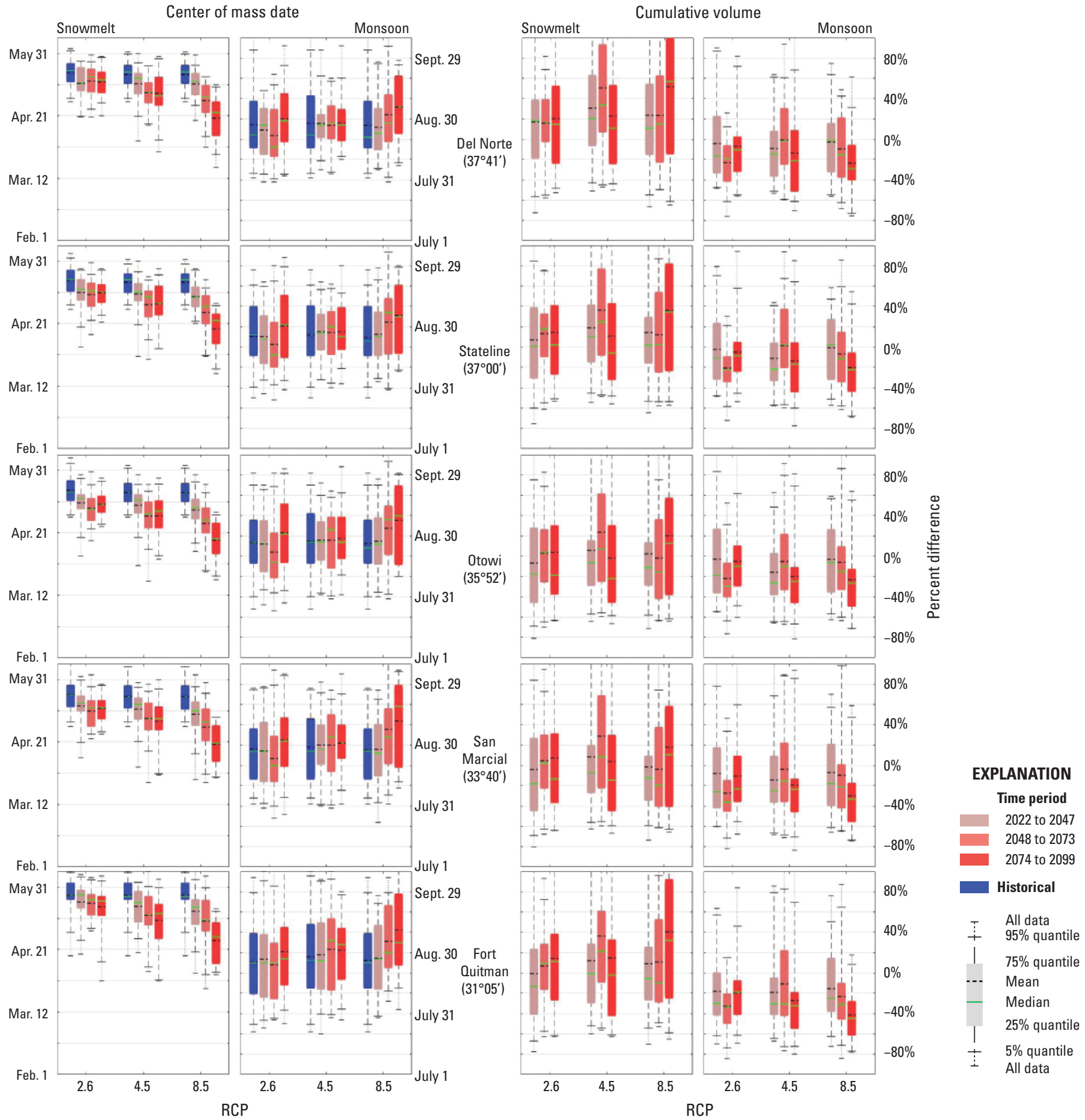

Figure 9. Differences in streamflow timing between historical observations and model projections (on the left) and percent differences in cumulative streamflow volume (on the right) for three future time periods based on the representative concentration pathways (RCPs) 2.6, 4.5, and 8.5 (from van Vuuren and others, 2011; Intergovernmental Panel on Climate Change, 2019) on Rio Grande main-stem streamgages in the Upper Rio Grande Basin. Graphs are ordered from top to bottom according to the upstream to downstream locations of the streamgages. See table 1 for streamgage information. 


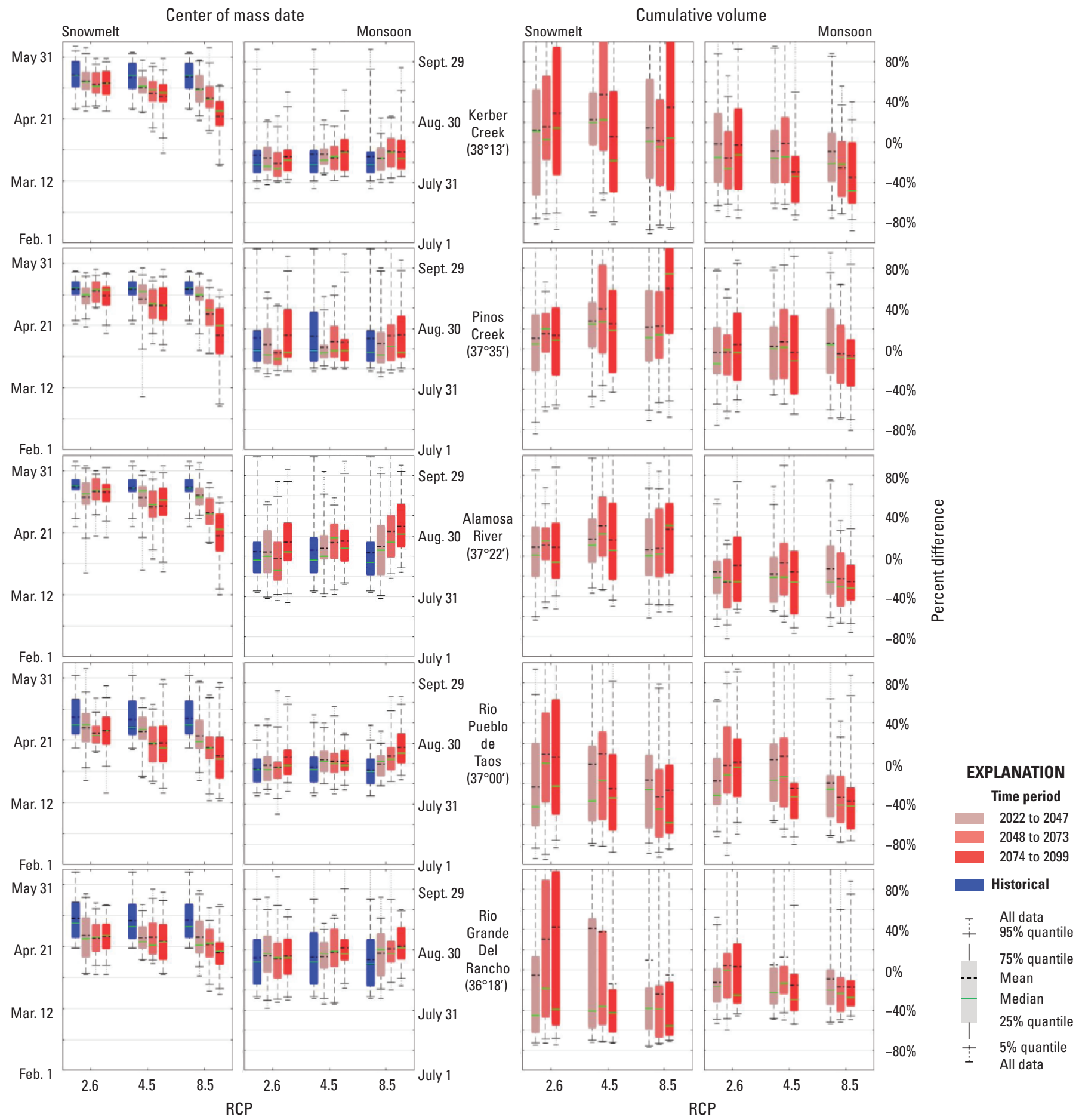

Figure 10. Differences in streamflow timing between historical observations and model projections (on the left) and percent differences in cumulative streamflow volume (on the right) for three future time periods based on the representative concentration pathways (RCPs) 2.6, 4.5, and 8.5 (from van Vuuren and others, 2011; Intergovernmental Panel on Climate Change, 2019) for near-native streamgages in the Upper Rio Grande Basin. Graphs are ordered from top to bottom according to the upstream to downstream locations of the streamgages. See table 1 for streamgage information. 


\section{Projected Changes in Streamflow Timing}

Compared to the large data variance with streamflow volume, changes in streamflow timing had a relatively small interquartile range of data output for all future time periods and RCP scenarios for the headwaters region, denoting a clearer trend captured by the mean (figs. 9, 10; table 2). The future change in streamflow timing at all near-native subbasin and main-stem gages displayed substantially earlier streamflow timing, and like changes in streamflow volume, cumulative yearly changes in streamflow timing were dictated by changes in snowmelt runoff timing. For all future time periods and all RCP scenarios, streamflow timing for the snowmelt season and for the water year occurred earlier in the year. For RCP 8.5 at the latest future time period, the main-stem gages at Del Norte and Stateline displayed earlier mean timing of up to 32 days during snowmelt season that, combined with slightly later monsoonal flows, resulted in a 27 day earlier mean timing for the water year (fig. 9; table 2). Similarly, the subbasin gages (for RCP 8.5 at the latest future time period) displayed earlier mean timing of up to 31 days during snowmelt season and 37 days for the water year (fig. 10; table 2). In general, streamflow timing shifted to later in the year during the monsoon season for all headwater gages with the largest mean increase of 18 days. However, because of the low contribution of rain relative to snow in the headwater subbasins, timing changes during monsoon season are minimal.

\section{Upper Rio Grande Region}

The Upper Rio Grande region of the basin includes the near-native subbasin gages Rio Pueblo de Taos, Rio Grande del Rancho, and Jemez River and one main-stem gage, Rio Grande at Otowi (fig. 1; table 1). Streamflow in the region is generated by seasonal snowpack falling in the Sangre de Cristo and Jemez Mountains and other high-elevation areas and by rain during the summer monsoon season (figs. 6-8). At the gages in the northern part of the region (Otowi, Rio Pueblo de Taos, Rio Grande del Rancho), peak streamflow historically occurs in May, whereas at the Jemez River gage, peak streamflow historically occurs in April.

\section{Projected Changes in Streamflow Volume}

The Otowi gage displayed a negligible annual change in mean streamflow volume through the RCP scenarios and future time periods. For RCP 8.5 at the latest future time period, this gage displayed a 4 percent mean increase in annual streamflow volume, a 20 percent increase during the snowmelt period, and a 23 percent decrease during the monsoon period (table 3 ). However, the Rio Pueblo de Taos and Rio Grande del Rancho gages, which capture flow at the base of the Sangre de Cristo Mountains on the eastern edge of the Upper Rio Grande Basin, displayed reductions in streamflow volume during both the snowmelt and monsoon periods. For RCP 8.5 at the latest future time period, the Rio Pueblo de Taos and Rio Grande del Rancho gages displayed reduced mean streamflow volume by 5-27 percent during snowmelt season and by 17-37 percent during monsoon season (fig. 10; table 3). These changes led to decreases in mean streamflow volume of 7-22 percent for the water year.

The Jemez River gage, on the western edge of the Rio Grande Basin, displayed substantial increases in mean streamflow volume for the water year for all RCP scenarios and future time periods. For RCP 8.5 at the latest future time period, this subbasin streamgage displayed a 48 percent increase in mean streamflow volume for the water year that was driven by increases in mean streamflow volume during the snowmelt season (fig. 11; table 3). However, the Jemez River gage displayed some of the largest annual variance and data skew (through all RCP scenarios and future time periods) of all analyzed gage points. The median values display the inverse, or a reduction in cumulative streamflow values for RCP 8.5 at the latest future time period. All streamgages displayed a large interquartile range of yearly values (interannual variance) and data skew in cumulative yearly volume differences during the snowmelt season. Despite this, all values within the interquartile range for the Rio Pueblo de Taos and Rio Grande del Rancho gages displayed reductions in annual streamflow volume for all future time periods at RCP 8.5.

\section{Projected Changes in Streamflow Timing}

Future changes in streamflow timing in the upper Rio Grande region were similar to future changes in the headwaters region and displayed relatively low interannual variance as compared to streamflow volume trends. In general, all gages in the Upper Rio Grande region displayed substantially earlier mean annual streamflow timing, and these changes were primarily due to changes in timing during the snowmelt season. The main-stem Otowi streamgage displayed earlier mean streamflow timing of 23 days for the water year (31 days earlier for snowmelt season) at RCP 8.5 at the latest future time period (fig. 9). Similarly, the near-native subbasin gages (for RCP 8.5 at the latest future time period) displayed earlier timing of up to 20 days during snowmelt season and 16 days for the water year (fig. 10, 11; table 2). In general, there were changes in timing toward later in the year during the monsoon season for all upper Rio Grande region gages, with the largest increase of 14 days. However, the contribution of streamflow timing changes from the monsoon season for the entire water year were minimal. These results highlight a higher contribution of precipitation during snowmelt season than monsoon season.

\section{Middle and Lower Rio Grande Regions}

The middle and lower regions of the watershed include three near-native subbasin gages, the Rio Puerco, Arroyo Chico, and Rio Salado, and two main-stem gages, the San Marcial and Fort Quitman (fig. 1; table 1). Streamflow in these regions is primarily generated by precipitation during the monsoon season (fig. 8). Streamflow at the Rio Puerco subbasin 


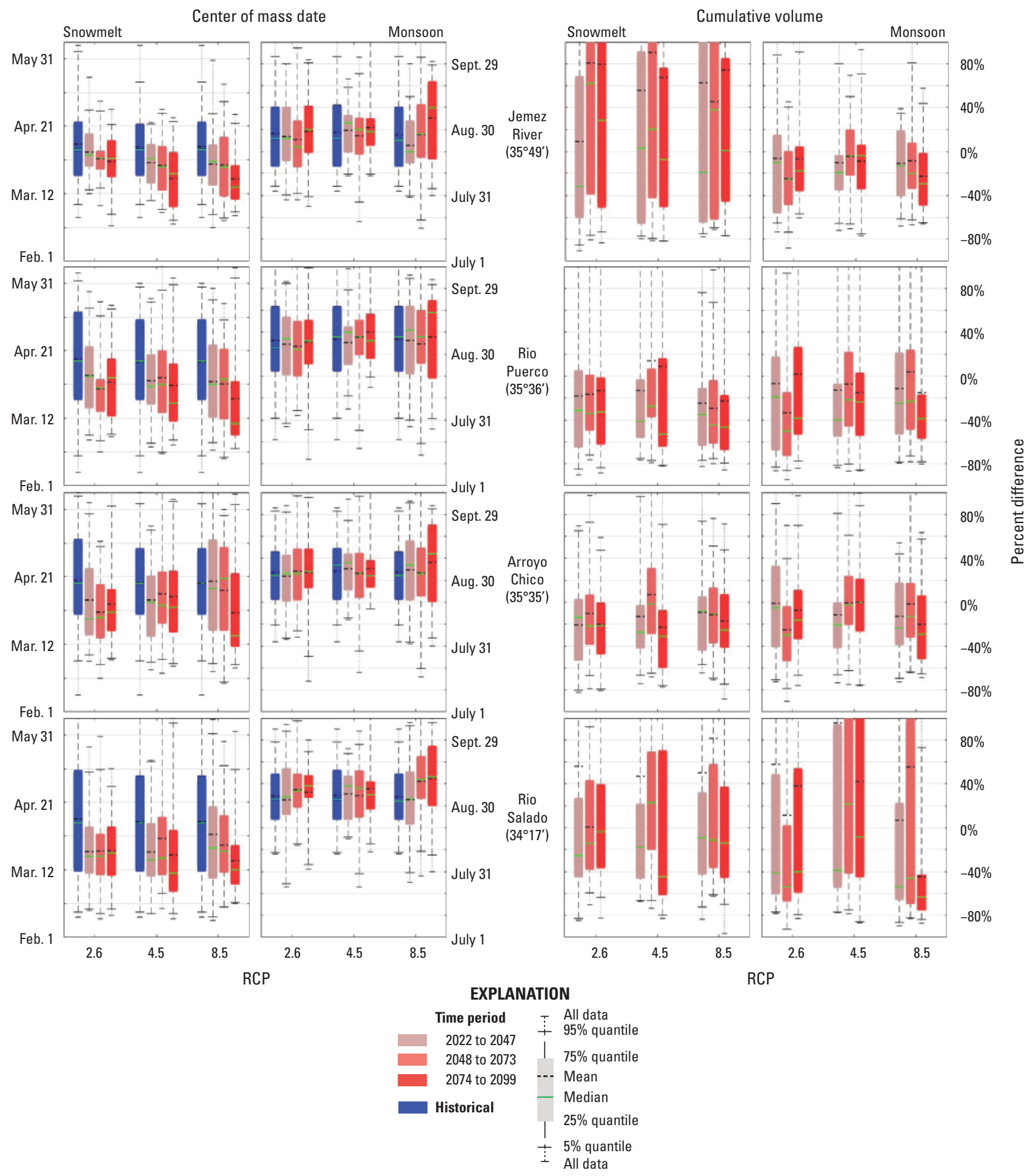

Figure 11. Differences in streamflow timing between historical observations and model projections (on the left) and percent differences in cumulative streamflow volume (on the right) for three future time periods based on the representative concentration pathways (RCPs) 2.6, 4.5, and 8.5 (from van Vuuren and others, 2011; Intergovernmental Panel on Climate Change, 2019) for near-native streamgages in the Upper Rio Grande Basin. Graphs are ordered from top to bottom according to the upstream to downstream locations of the streamgages. See table 1 for streamgage information. 
historically has peaks in the snowmelt season (May) and in the monsoon season (August). Streamflow at the Arroyo Chico and Rio Salado subbasins generally has peaks in August during the monsoon season interspersed with periods where there is almost no flow.

\section{Projected Changes in Streamflow Volume}

As with the Otowi main-stem gage in the Upper Rio Grande region, the two main-stem gages in the Middle and Lower Rio Grande regions displayed relatively low overall changes in streamflow volume for the water year through the RCP scenarios and future time periods. For RCP 8.5 at the latest future time period, the main-stem gages displayed reductions in mean streamflow ranging between 0 and 2 percent (fig. 9; table 3). Streamflow volume during the snowmelt season increased substantially (18-40 percent increase for RCP 8.5 at the latest future time period), but these volumetric increases were outcompeted with the larger cumulative influence of monsoon season precipitation. The main-stem gages displayed decreases in mean streamflow volume of 30-41 percent during monsoon season (fig. 9). The near-native subbasin gages displayed reductions in mean streamflow volume for the water year of 12-17 percent for RCP 8.5 at the latest future time period. In general, streamflow volume decreased for all RCP scenarios and future time periods for the snowmelt season, monsoon season, and water year. However, the primary influence to changes during the water year occurred only during the monsoon season (between 15 and 45 percent lower for RCP 8.5 at the latest future time period) because the majority of the runoff in these near-native subbasins is flashy and originates from monsoon events (fig. 11). Similar to all other gages in the basin, these near-native subbasin gages displayed a large interquartile range of yearly values (interannual variance) and data skew in cumulative yearly volume differences (figs. 9, 11; table 3).

\section{Projected Changes in Streamflow Timing}

The main-stem gages in the Middle and Lower Rio Grande regions displayed some of the largest changes to streamflow timing in the Upper Rio Grande Basin and displayed relatively low interannual variance as compared to streamflow volume trends. All RCP scenarios and future time periods showed substantially earlier streamflow timing for the water year. For RCP 8.5 at the latest future time period, mean streamflow timing was 23-28 days earlier at the main-stem gages for the water year (fig. 9; table 2). As with all other main-stem gages in the basin, earlier timing was primarily attributed to changes during the snowmelt season. The near-native subbasins displayed minor changes in streamflow timing for the water year. For RCP 8.5, at the latest future time period, the mean change in streamflow timing ranged from 7 days earlier to 5 days later. There was a minimal influence of changes in streamflow timing during snowmelt season because of the minor contribution of precipitation during snowmelt season relative to the monsoon season.

\section{Spatial Analysis of Projected Change in Streamflow Across the Upper Rio Grande Basin}

\section{Projected Changes in Streamflow Volume}

Changes in streamflow volume vary across the Upper Rio Grande Basin. In general, the spatial differences are controlled by latitude. The headwaters region displays small increases in cumulative volume for the water year (fig. 12). Despite this being one of the primary water-generating areas of the basin, these increases are conflated by decreases in cumulative volume in other areas and contribute to either a negligible or a small decrease in total volume at the Upper Rio Grande Basin outlet at Fort Quitman. The conflicting spatial patterns of increase and decrease in cumulative volume regardless of $\mathrm{RCP}$ and future time period become clearer when the change in cumulative volume for the water year (fig. 12) is separated into snowmelt (fig. 13) and monsoon (fig. 14) seasons.

Changes in cumulative streamflow volume during the snowmelt season led to either negligible or modest increases in cumulative volume at the Upper Rio Grande Basin outlet (fig. 13). In general, simulated streamflow in the subbasins in the headwaters region displayed increases in volume, whereas simulated streamflow in most of the subbasins in the other regions displayed decreases in volume. These differences highlight the snow-dominated nature and strong control of the headwaters region on the Upper Rio Grande Basin as a whole regardless of RCP or time period. Despite reductions in cumulative volume in the headwaters region during the monsoon season (fig. 14), these changes were not large enough to overcome changes in cumulative volume during the snowmelt period (fig. 13), which is why increases are seen for the entire water year in the headwaters region (fig. 12). The other snowdominated and primary water-generating area of the basin, the Sangre de Cristo Mountains (in the Upper Rio Grande region), did not display increases in cumulative volume during snowmelt. Rather, this area (around the Rio Grande del Rancho and Rio Pueblo de Taos near-native subbasins) displayed decreases in cumulative volume for both the snowmelt and monsoon seasons.

In general, the Middle and Lower Rio Grande regions displayed large percent decreases in cumulative volume for the snowmelt season. However, this led to little change at the basin outlet because these areas undergo minimal snowmelt relative to the headwaters and Upper Rio Grande regions. These areas are dominated by monsoonal activity, and as such, changes seen during the monsoon season (fig. 14) are similar to the changes seen for the entire water year (fig. 12).

\section{Projected Changes in Streamflow Timing}

As time and RCP increased, substantial changes in streamflow timing toward earlier in the year were seen on the Rio Grande main stem (fig. 15). No substantial changes were seen in streamflow timing for the water year at the basin outlet in the first future time period for any RCP. However, for all RCP scenarios in the other two future time periods, 


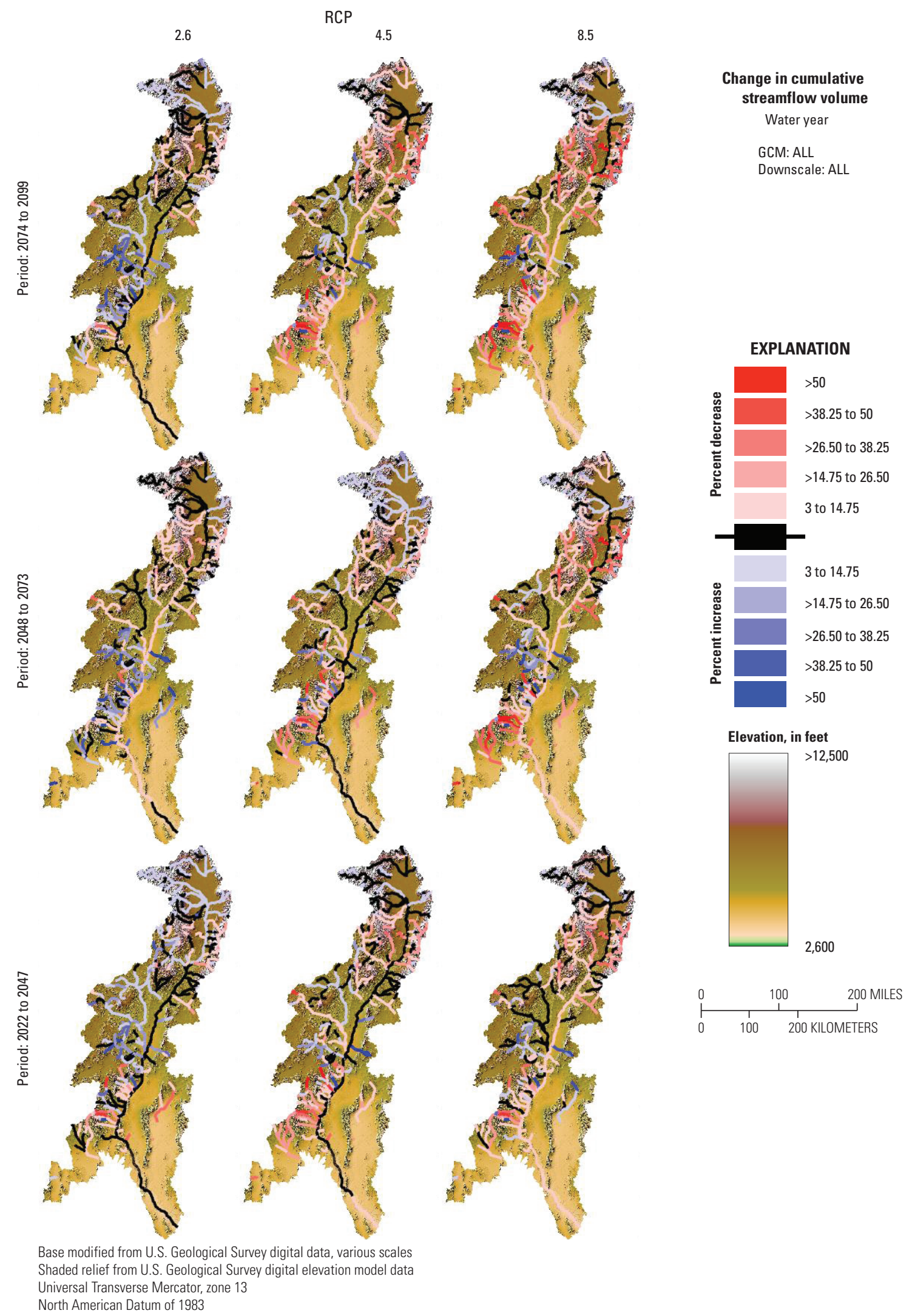

Figure 12. Projected change in cumulative streamflow volume for all Precipitation-Runoff Modeling System stream segments for the water year using the ensemble mean of general circulation models (GCMs) and downscaling scenarios for three future time periods based on the representative concentration pathways (RCPs) 2.6, 4.5, and 8.5 (from van Vuuren and others, 2011; Intergovernmental Panel on Climate Change, 2019). 


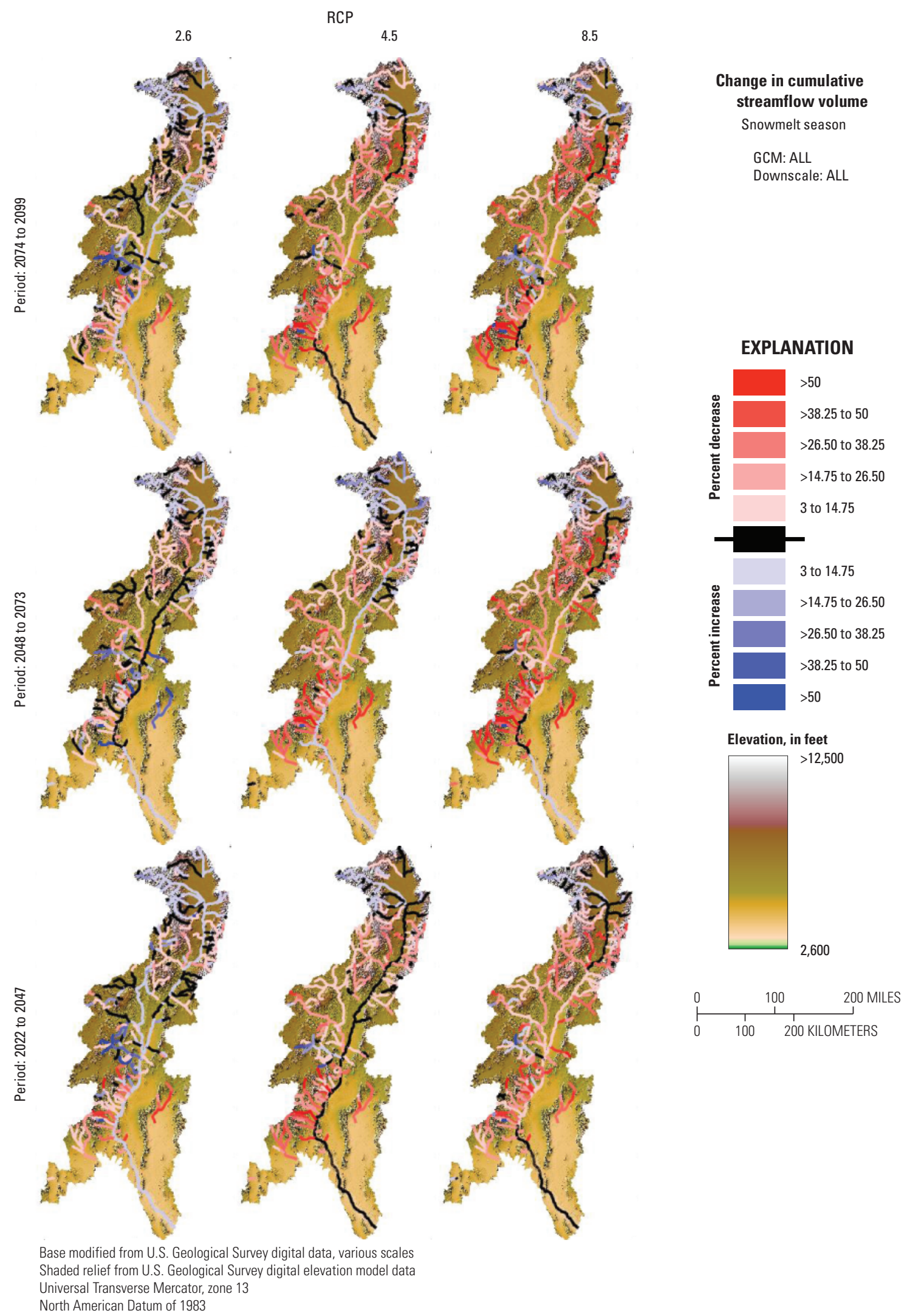

Figure 13. Projected change in cumulative streamflow volume for all Precipitation-Runoff Modeling System stream segments for snowmelt season using the ensemble mean of general circulation models (GCMs) and downscaling scenarios for three future time periods based on the representative concentration pathways (RCPs) 2.6, 4.5, and 8.5 (from van Vuuren and others, 2011; Intergovernmental Panel on Climate Change, 2019). 


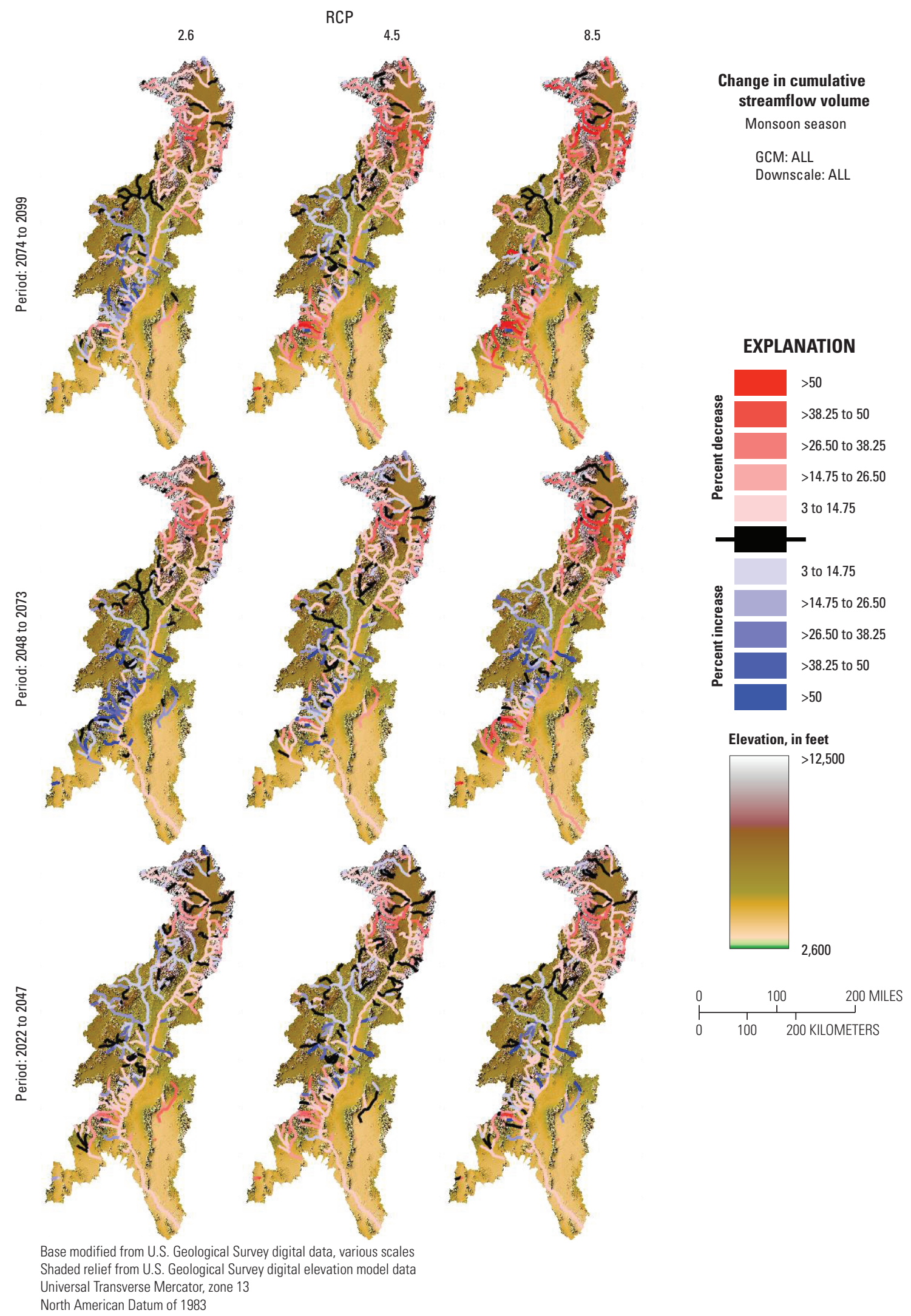

Figure 14. Projected change in cumulative streamflow for all Precipitation-Runoff Modeling System stream segments for monsoon season using the ensemble mean of general circulation models (GCMs) and downscaling scenarios for three future time periods based on the representative concentration pathways (RCPs) 2.6, 4.5, and 8.5 (from van Vuuren and others, 2011; Intergovernmental Panel on Climate Change, 2019). 


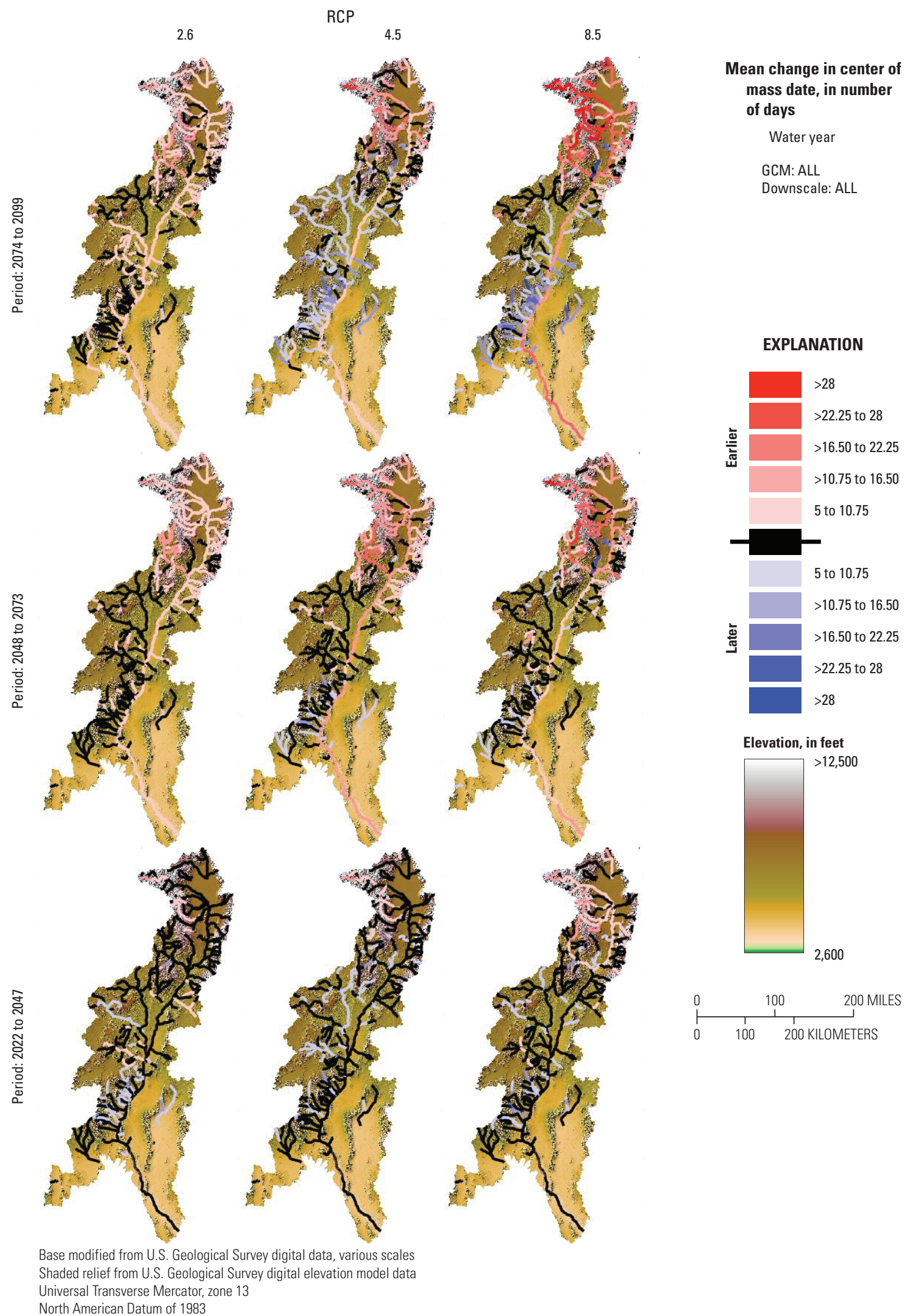

Figure 15. Projected change in streamflow timing for all Precipitation-Runoff Modeling System stream segments for the water year using the ensemble mean of general circulation models (GCMs) and downscaling scenarios for three future time periods based on the representative concentration pathways (RCPs) 2.6, 4.5, and 8.5 (from van Vuuren and others, 2011; Intergovernmental Panel on Climate Change, 2019). 


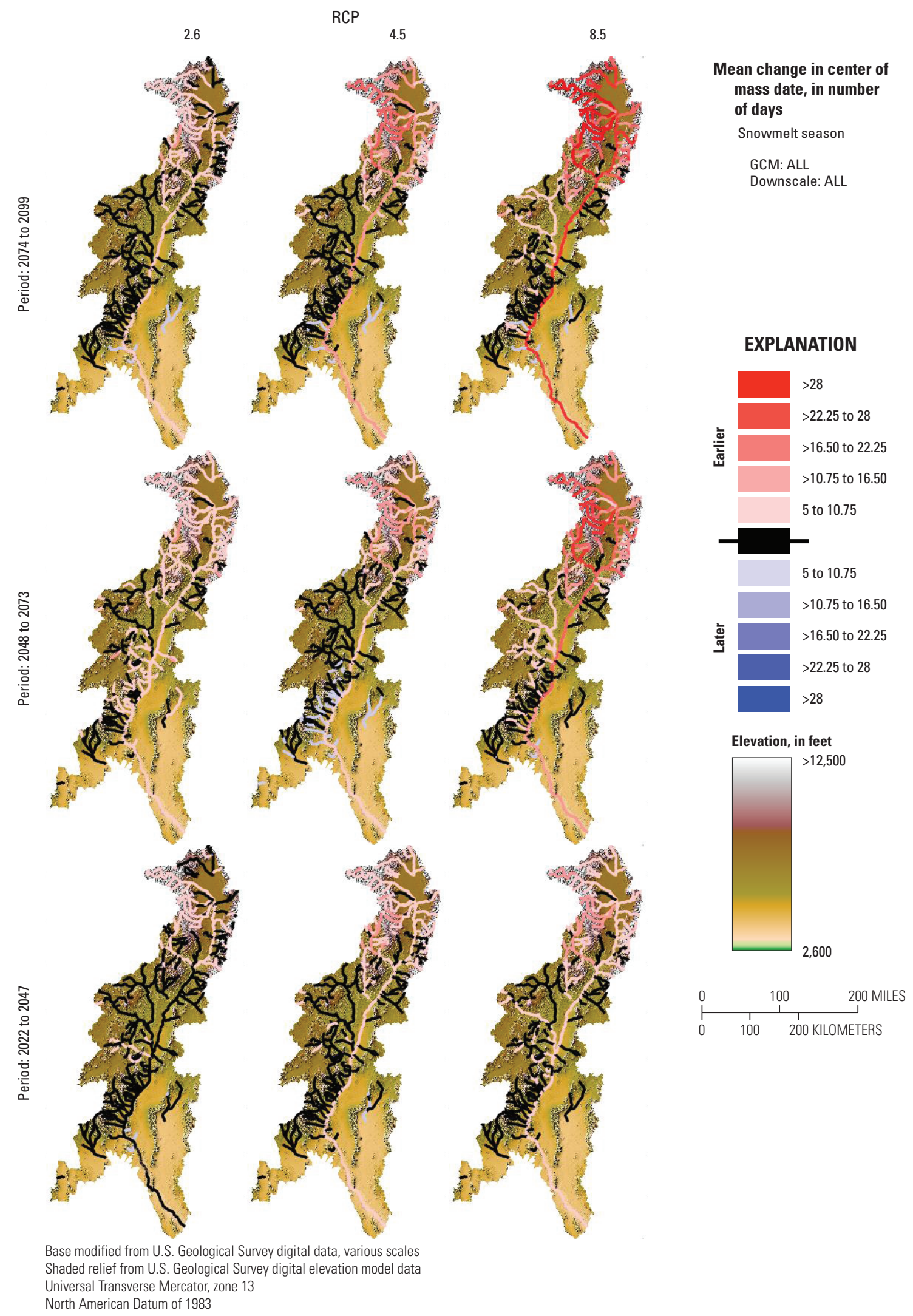

Figure 16. Projected change in streamflow timing for all Precipitation-Runoff Modeling System stream segments for the snowmelt season using the ensemble mean of general circulation models (GCMs) and downscaling scenarios for three future time periods based on the representative concentration pathways (RCPs) 2.6, 4.5, and 8.5 (from van Vuuren and others, 2011; Intergovernmental Panel on Climate Change, 2019). 


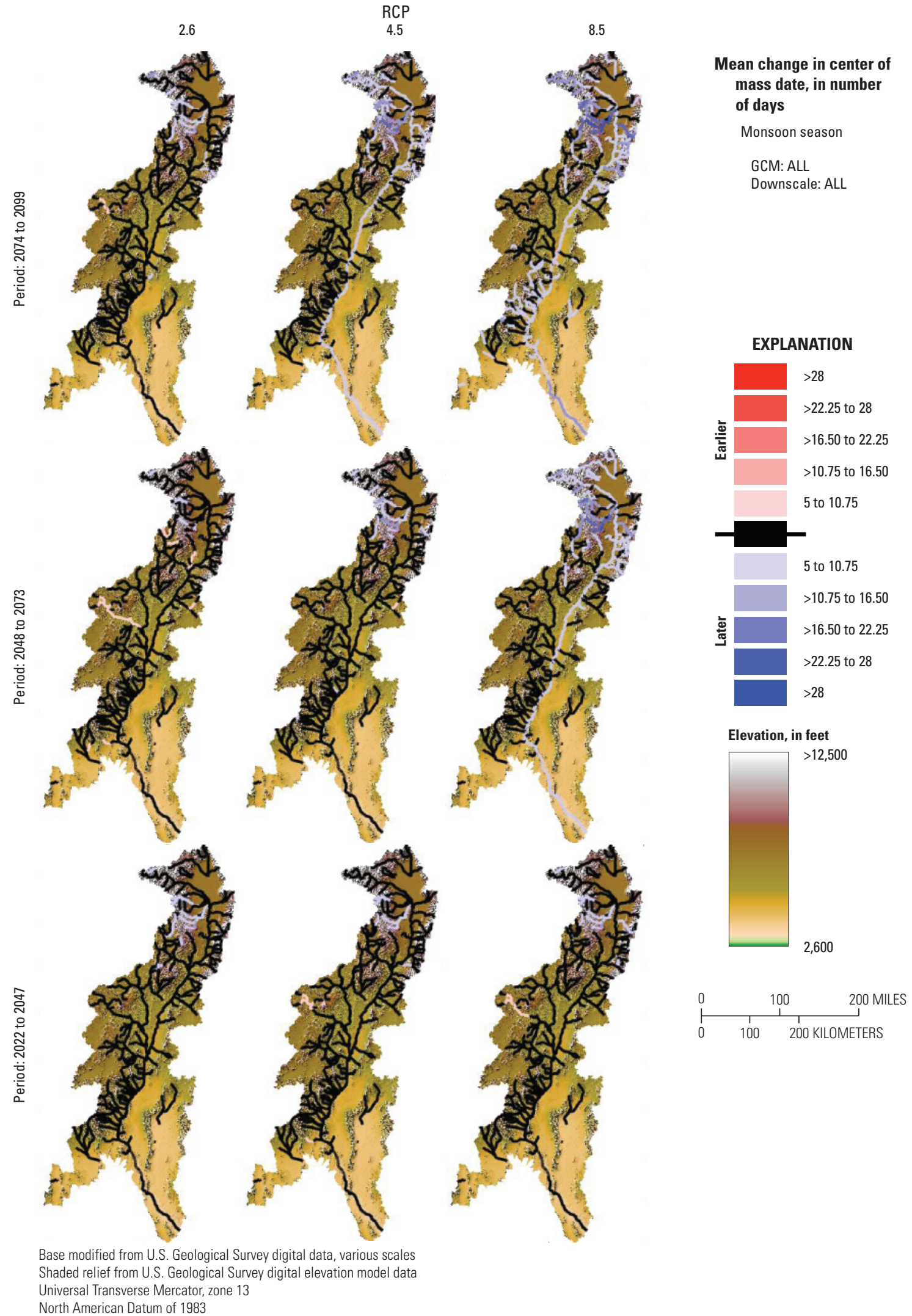

Figure 17. Projected change in streamflow timing for all Precipitation-Runoff Modeling System stream segments for the monsoon season using the ensemble mean of general circulation models (GCMs) and downscaling scenarios for three future time periods based on the representative concentration pathways (RCPs) 2.6, 4.5, and 8.5 (from van Vuuren and others, 2011; Intergovernmental Panel on Climate Change, 2019). 
substantially earlier streamflow was seen. These changes were primarily due to earlier snowmelt and subsequent runoff (fig. 16). The increasingly earlier streamflow timing with later future time periods and higher RCP scenarios in the headwaters region during snowmelt season (fig. 16) is juxtaposed with changes in the streamflow timing during monsoon season, where only limited changes were seen on the Rio Grande main stem (fig. 17). For the majority of the subbasins in the Upper Rio Grande Basin, little to no changes were projected for the monsoon season. However, in the headwaters region and in subbasins with high mean elevations, streamflow timing was slightly later during monsoon season, but this signal was not large enough to overcome earlier streamflow during snowmelt season to affect the water year response. These projections highlight that the timing of streamflow on the Rio Grande is dependent on snowmelt and that changes in snowmelt timing are primarily determined by the headwaters region.

\section{Discussion}

In general, increasing radiative forcings due to higher RCP scenario and later future time period displayed increasing changes to volume and timing of streamflow from PRMS simulations. Near-native subbasin gages displayed larger changes in streamflow volume with higher RCP and later future time period than did the main-stem gages. The mainstem gages cumulate differences between RCP scenarios and future time periods over larger spatial scales than do the nearnative subbasin gages. As such, main-stem gages in the Upper Rio Grande Basin have acted to average large and sometimes conflicting streamflow volume responses in the watershed, resulting in a smaller streamflow volume change signal.

For example, for RCP 8.5 at the latest future time period, the amount of change in streamflow volume on a main-stem gage is directly related to increasing upstream basin area. From upstream to downstream, average streamflow volume on the Rio Grande main-stem gages for the water year changes as follows: 28 percent (38 percent median) at Del Norte, 18 percent (18 percent median) at Stateline, 4 percent ( 3 percent median) at Otowi, 0 percent ( -3 percent median) at San Marcial, and -2 percent ( -8 percent median) at Fort Quitman. As such, changes in streamflow volume were initiated from positive changes in snowmelt from the headwaters region and interacted with negative changes in monsoonal precipitation farther south in the watershed.

The change in streamflow timing did not share this pattern. The change in streamflow timing was initiated in the headwaters region and changed little from upstream to downstream on the main-stem gages. All main-stem gages displayed earlier timing by an average of 23 days (28 days median) to 28 days ( 35 days median) for RCP 8.5 at the latest future time period. The change in streamflow timing was initiated during the snowmelt season and was due to increasing temperature through time and an RCP scenario that resulted in earlier snowmelt. With increased radiative forcing, the extent of change in streamflow timing change migrates southward (fig. 16, RCP 4.5), but the increased temperature seemingly has little effect on streamflow timing on the Rio Grande main stem south of the headwaters region. It is not until the last future time period, with little to no effort to mitigate greenhouse gases (RCP 8.5), that substantial changes in streamflow timing occur both on the Rio Grande main stem south of the headwaters and in tributaries in the headwaters and Upper Rio Grande regions (the area that generates more than 85 percent of Rio Grande flow).

The difference in the spatial patterns between potential changes in streamflow timing and volume highlights differences between potential future changes in precipitation and temperature patterns. Specifically, the pattern of future precipitation changes is more spatially variable than that of future temperature changes. The interannual variance of potential changes in streamflow volume was also much larger than the interannual variance of potential changes in streamflow timing at all RCP scenarios and future time periods. These results indicate that volume of precipitation under increased radiative forcing varies more over space than does the timing of precipitation.

Increases in streamflow volume during snowmelt season in the headwaters region (figs. 10,13) did not relate to higher peak flows (fig. 7). This was due to increasing temperature creating not just earlier peak flows but also a longer snowmelt pulse starting earlier and causing a reduction in melt rates. This counterintuitive finding has also been highlighted by other work, such as that of Nolin and Daly (2006), Musselman and others (2017a, b), and Sexstone and others (2020), that displayed lower melt rates in lower to middle snow-dominated elevations that were more affected by slight temperature changes.

\section{Critical Zones}

There were areas in the Upper Rio Grande Basin that displayed much larger changes than others. The southern Sangre de Cristo Mountains region around the Rio Pueblo de Taos and Rio Grande del Rancho near-native subbasins displayed substantial decreases in streamflow volume through time. These two near-native subbasins displayed median streamflow volume losses for almost all RCP scenarios and future time periods. For RCP 8.5 at the latest future time period, the median loss ranged between 45 and 46 percent for the water year. These are currently snow-dominated subbasins, and unlike the other snow-dominated subbasins in the northern part of the study area, there were significant reductions in streamflow volume during the snowmelt period at all RCP scenarios and future time periods (median loss ranging between 56 and 59 percent for RCP 8.5 at the latest future time period). This region also displayed substantial reductions in median streamflow volume during the monsoon season. All RCP scenarios and future time periods displayed this pattern, 
and for RCP 8.5 at the latest future time period, there was a median reduction between 28 and 42 percent. This region also displayed earlier streamflow timing for the water year and during the snowmelt period and later streamflow timing during the monsoon season. For RCP 8.5 at the latest future time period, streamflow was approximately 2 weeks earlier for the water year. However, this was not as early as at the main-stem gages and the other near-native subbasin gages in the headwater and Upper Rio Grande regions.

In the Jemez River subbasin, which has its headwaters in the Jemez Mountains, projected changes in streamflow timing for the water year and during the snowmelt season were notable. Changes in both mean and median water year values were mainly positive, meaning that streamflow either increased relative to the historical period or underwent minimal losses ( 7 percent decrease for RCP 8.5 at the latest future time period) and during the snowmelt season streamflow mostly increased, whereas during the monsoon season notable decreases in streamflow were seen. The Jemez River has a bimodal streamflow pattern with higher runoffs occurring during snowmelt and monsoon seasons, but because most of Jemez River streamflow is generated in the snowmelt season, it acts like the snow-dominated basins in the headwaters region, where streamflow increases as the timing of streamflow shifts toward earlier in the season. Although mean and median streamflow volume increases from historical streamflow, changes in streamflow volume under all RCP scenarios displayed a substantial amount of variability (plus or minus 80 percent change) during the snowmelt season. Therefore, predicting how streamflow volume in the Jemez River will be impacted is less certain.

Results discussed in Elias and others (2015) using a snowmelt runoff model forced by future projections of climate for subbasins in snowmelt-driven basins can be qualitatively compared to results for subbasins in the headwaters and Upper Rio Grande regions from the current study. Sites simulated by the snowmelt runoff model in the San Juan and Sangre de Cristo Mountains that coincide with sites in the headwaters region presented herein for the current study include Rio Grande del Norte, Rio Grande del Rancho, and Rio Pueblo de Taos. Under the most extreme scenarios (hotter/wetter, hotter/ drier) for the end of 21st century presented in Elias and others (2015), the total annual streamflow volume increased by as much as 25 percent at the Rio Grande del Norte streamgage under the hotter/wetter scenario and decreased by as much as 24 percent in the hotter/drier scenario. In comparison, median annual streamflow under RCP 8.5 at the latest time period in the current study showed a mean 28 percent ( 38 percent median) increase in streamflow volume at the Rio Grande del Norte streamgage (fig. 9). Elias and others (2015) also reported that annual streamflow volume in the Rio Grande del Rancho and Rio Pueblo de Taos increased 25 percent under the hotter/wetter scenario and decreased 24 percent in the hotter/drier scenario, whereas herein for the current study we report a mean 7-22 percent reduction in streamflow (46 percent median reduction) under the RCP 8.5 scenario.
Direct comparisons of results in the current study, other than headwater tributary flows, cannot be made with results in the Upper Rio Grande Impact Assessment (Llewellyn and Vaddey, 2013), which incorporates the impact of water operations on the hydrologic system from streamflow changes, because this model in the current study was precisely calibrated to represent naturalized flow. The impacts of water operations increase downstream in the Upper Rio Grande Basin, making downstream comparisons even less appropriate. Headwater tributaries that were used to drive flows in the water operations model for the Upper Rio Grande Impact Assessment simulated a 33 percent decrease in average annual flow (Llewellyn and Vaddey, 2013), whereas the current study simulated variable changes (increases and decreases) at the Stateline streamgage.

\section{Limitations and Assumptions}

The simulated PRMS responses were largely driven by the chosen GCMs and downscaling methods. As a result, any uncertainties with these datasets, including assimilated observational datasets, temporal and spatial data discontinuities, and model physics, were propagated to the PRMS model. However, the GCMs and downscaling methods were chosen to reflect the range of GCM projected changes in the south-central United States (Wootten and others, 2017). The ensemble of these data was used and the analysis was based on the entire range of output from these different GCMs and downscaling methods in order to reduce dependence on a singular data source. An ensemble of downscaled GCMs better represents a plausible range of climatological forcing on hydrology that can be used to assess hydrologic response at the local scale than does the use of one specific GCM (Sheshukov and others, 2011; Winkler and others, 2011; Sheshukov and Douglas-Mankin, 2017). In addition, the current study also incorporated three RCPs, thereby representing a range of scenarios that could occur as a result of human action. Therefore, the PRMS simulations presented herein are presumed to incorporate much of the uncertainty associated with multiple sources in the climate projections including RCPs, GCMs, and downscaling techniques (Wootten and others, 2017). While the downscaling techniques used are not among the most sophisticated, they do reflect downscaling techniques that are generally considered accurate enough to be used in impact assessments in the United States and globally (Wootten and others, 2020).

The PRMS model did not integrate changes to the land surface over time. The Upper Rio Grande Basin is undergoing large changes to the landscape primarily from forest fires and bark beetle infestations. Already, 85 percent of the coniferous forests in the headwaters region have been affected by the bark beetle, and projections display even greater changes from forest fires as the climate warms (U.S. Department of Agriculture Forest Service, 2018, 2019). Forests are key determinants of water supply, quality, and quantity, and their importance 
is increasing as freshwater resources become scarcer (Bates and others, 2008; Furniss and others, 2010). These forest disturbances change biophysical processes (for example, interception and transpiration) and are important drivers of hydrological variation. Already, forest disturbance has affected many areas with seasonal snow, and in the headwater regions of the Rio Grande and Colorado River Basins, burn areas are projected to increase $300-700$ percent with a 1-degree Celsius increase in average global temperature (National Research Council, 2011). However, to date, there is a limited understanding of how these changes would affect downstream water resources (Sexstone and others, 2018). Furthermore, the PRMS model is not a fully physically based model for the snow process within the model and cannot integrate the complex subgrid heterogeneity of forest-snow interactions.

There has long been a complaint that PRMS and other distributed-parameter hydrology models have too many input parameters (Kirchner, 2006; Markstrom and others, 2016) and that some of these parameters may constrain the model in unintended ways (Hrachowitz and others, 2014). It is also possible that some calibrated model parameters may not be valid in future time periods. Despite the highly calibrated nature of the PRMS model and initial parameter sensitivity analysis, it is unclear how these calibrated parameters perform in differing environments such as those seen in water year 2099.

\section{Conclusion}

The Rio Grande is a vital source of water for populations in three southwestern States and northern Mexico. Already, streamflow on the Rio Grande and its tributaries is overallocated, and potential future changes presented in this report highlight the necessity to improve planning and water-saving measures in this Upper Rio Grande Basin as populations increase. Anthropogenic influences compounded with climate change can affect water availability management and use in the basin. Global climate models project a continued increase in temperature, but changes in precipitation are less certain.

The RCP-based analysis of projected impacts to naturalized streamflow in the Upper Rio Grande Basin incorporating spatial, annual, and seasonal changes showed a clear pattern toward substantially earlier streamflow timing in all reaches of the Rio Grande, with the largest changes occurring with RCPs representing little to no effort to mitigate greenhouse gases (RCP 4.5, 8.5). The magnitude of these changes is dependent on location in the basin and whether the majority of streamflow is generated by snowmelt or summer monsoons. Changes in overall streamflow volume are more variable than changes in streamflow timing and change significantly depending on region and subbasin within the Upper Rio Grande Basin.

The streamflow projections from the Upper Rio Grande Basin PRMS model offer an indication of how the Rio Grande and its tributaries may be affected by different climate scenarios. The results presented herein are of naturalized streamflow, which allow for comparisons between historical and projected streamflow without having to account for changes in water management. With actual streamflow on the Rio Grande and its tributaries already overallocated, the changes projected by the model would only exacerbate the affect that climate change has and would have on streamflow in the Upper Rio Grande Basin. In order to determine how anthropogenic influence on streamflow would affect water availability and use, these streamflow projections can be combined with water operation models.

\section{References Cited}

Archfield, S.A., Kennen, J.G., Carlisle, D.M., and Wolock, D.M., 2014, An objective and parsimonious approach for classifying nature flow regimes at a continental scale: River Research and Applications, v. 30, no. 9, p. 1166-1183. [Also available at https://doi.org/10.1002/rra.2710.]

Bates, B.C., Kundzewicz, Z.W., Wu, S., and Palutikof, J.P., eds., 2008, Climate change and water. Technical paper of the Intergovernmental Panel on Climate Change: Geneva, IPCC Secretariat, $210 \mathrm{p}$.

Bertrand, D., and McPherson, R.A., 2019, Development of downscaled climate projections-A case study of the Red River Basin, south-central U.S.: Advances in Meteorology, v. 2019, art. 4702139. [Also available at https://doi.org/ 10.1155/2019/4702139.]

Blodgett, D.L., Booth, N.L., Kunicki, T.C., Walker, J.I., and Viger, R.J., 2011, Description and testing of the Geo Data Portal-A data integration framework and web processing services for environmental science collaboration: U.S. Geological Survey Open-File Report 2011-1157, 9 p., accessed March 2019 at https://doi.org/10.3133/ ofr 20111157.

Chavarria, S.B., and Gutzler, D.S., 2018, Observed changes in climate and streamflow in the Upper Rio Grande Basin: Journal of the American Water Resources Association, v. 54, no. 3, p. 644-659. [Also available at https://doi.org/10.1111/ 1752-1688.12640.]

Chavarria, S.B., Moeser, C.D., and Douglas-Mankin, K.R., 2020a, Application of the Precipitation-Runoff Modeling System (PRMS) to simulate near-native streamflow in the Upper Rio Grande Basin: U.S. Geological Survey Scientific Investigations Report 2020-5026, 38 p., accessed January 2, 2020, at https://doi.org/10.3133/sir20205026.

Chavarria, S.B., Moeser, C.D., Ball, G.P., and Shephard, Z.M., 2020b, Hydrologic simulations using projected climate data as input to the Precipitation-Runoff Modeling System (PRMS) in the Upper Rio Grande Basin (ver. 2.0, September 2021): U.S. Geological Survey data release, https://doi.org/10.5066/P9ML93QB. 
Clarke, L., Edmonds, J., Jacoby, H., Pitcher, H., Reilly, J., and Richels, R., 2007, Scenarios of greenhouse gas emissions and atmospheric concentrations: Washington, D.C., Department of Energy, Office of Biological \& Environmental Research, Sub-report 2.1A of Synthesis and Assessment Product 2.1, U.S. Climate Change Science Program and the Subcommittee on Global Change Research, $154 \mathrm{p}$.

Clow, D.W., 2010, Changes in the timing of snowmelt and streamflow in Colorado-A response to recent warming: Journal of Climate, v. 23, no. 9, p. 2293-2306. [Also available at https://doi.org/10.1175/2009JCLI2951.1.]

Dettinger, M., Udall, B., and Georgakakos, A., 2015, Western water and climate change: Ecological Applications, v. 25, no. 8, p. 2069-2093. [Also available at https://doi.org/ 10.1890/15-0938.1.]

DiNatale Water Consultants, 2014, Rio Grande Basin water plan: Colorado Water Conservation Board, Rio Grande Basin Roundtable, prepared by DiNatale Water Consultants, Boulder, Colo., 388 p., accessed January 2019 at https ://www.colorado.gov/pacific/sites/default/files/14Water ResourcesBasinImplementationPlanRioGrandeBasin.pdf.

Dixon, K.W., Wootten, A.M., Nath, M.J., Lanzante, J., AdamsSmith, D.J., Whitlock, C.E., Gaitán, C.F., and McPherson, R.A., 2020, South Central Climate Projections Evaluation Project (C-PrEP): Norman, Okla., South Central Climate Adaptation Science Center web page, accessed January 2, 2021, at https://doi.org/10.21429/12gk-dh47.

Douglas-Mankin, K.R., and Moeser, C.D., 2019, Calibration of Precipitation-Runoff Modeling System (PRMS) to simulate prefire and postfire hydrologic response in the upper Rio Hondo Basin, New Mexico: U.S. Geological Survey Scientific Investigations Report 2019-5022, 25 p., accessed August 2019 at https://doi.org/10.3133/sir20195022.

Driscoll, J.M., Markstrom, S.L., Regan, R.S., Hay, L.E., and Viger, R.J., 2017, National Hydrologic Model Parameter Database-2017-05-08 download: U.S. Geological Survey web page, accessed March 2017 at https://doi.org/10.5066/ F7NSOSCW.

Elias, E.H., Rango, A., Steele, C.M., Mejia, J.F., and Smith, R., 2015, Assessing climate change impacts on water availability of snowmelt-dominated basins of the Upper Rio Grande Basin: Journal of Hydrology, Regional Studies, v. 3, p. 525-546.

Farnsworth, R.K., Thompson, E.S., and Peck, E.L., 1982, Evaporation atlas for the contiguous 48 United States: Washington, D.C., U.S. Department of Commerce, National Oceanic and Atmospheric Administration [NOAA], NOAA Technical Report NWS 33, 26 p.
Furniss, M., Staab, B., Hazelhurst, S., Clifton, C., Roby, K., Ilhadrt, B., and Edwards, P., 2010, Water, climate change, and forests-Watershed stewardship for a changing climate: U.S. Department of Agriculture [USDA], Forest Service, Pacific Northwest Research Station General Technical Report PNW-GTR-812 (June 2010), 75 p. [Also available at https://www.fs.fed.us/pnw/pubs/pnw_gtr812.pdf.]

Gangopadhyay, S., Pruitt, T., and Brekke, L., 2011, West-wide climate risk assessments-Bias-corrected and spatially downscaled surface water projections: U.S. Department of the Interior, Bureau of Reclamation, Technical Service Center, $138 \mathrm{p}$.

Gent, P.R., Danabasoglu, G., Donner, L.J., Holland, M.M., Hunke, E.C., Jayne, S.R., Lawrence, D.M., Neale, R.B., Rasch, P.J., Vertenstein, M., Worley, P.H., Yang, Z.-L., and Zhang, M., 2011, The Community Climate System Model version 4: Journal of Climate, v. 24, no. 19, p. 4973-4991. [Also available at https://doi.org/10.1175/2011JCLI4083.1.]

Gettelman, A., and Rood, R.B., 2016, Demystifying climate models-A users guide to Earth system models: Springer Nature, 274 p.

Giorgetta, M.A., Jungclaus, J., Reick, C.H., Legutke, S., Bader, J., Bottinger, M., Brovkin, V., Crueger, T., Esch, M., Fieg, K., Glushak, K., Gayler, V., Haak, H., Hollweg, H.-D., Ilyina, T., Kinne, S., Kornblueh, L., Matei, D., Mauritsen, T., Mikolajewicz, U., Mueller, W., Notz, D., Pithan, F., Raddatz, T., Rast, S., Redler, R., Roeckner, E., Schmidt, H., Schnur, R., Segschneider, J., Six, K.D., Stockhause, M., Timmreck, C., Wegner, J., Widmann, H., Wieners, K.-H., Claussen, M., Marotzke, J., and Stevens, B., 2013, Climate and carbon cycle changes from 1850 to 2100 in MPI-ESM simulations for the Coupled Model Intercomparison Project phase 5: Journal of Advances in Modeling Earth Systems, v. 5, no. 3, p. 572-597. [Also available at https://doi.org/ 10.1002/jame.20038.]

Glaser, L.S., 1998, The San Juan-Chama Project: Bureau of Reclamation History Program report, 28 p., accessed November 2019 at https://www.usbr.gov/projects/ pdf.php?id $=186$.

Gleeson, T., Smith, L., Moosdorf, N., Hartmann, J., Dürr, H.H., Manning, A.H., van Beek, L.P.H., and Jellinek, A.M., 2011, Mapping permeability over the surface of the Earth: Geophysical Research Letters, v. 38, no. 2, p. 1-6. [Also available at https://doi.org/10.1029/2010GL045565.] 
Gonzalez, P., Garfin, G.M., Breshears, D.D., Brooks, K.M., Brown, H.E., Elias, E.H., Gunasekara, A., Huntly, N., Maldonado, J.K., Mantua, N.J., Margolis, H.G., McAfee, S., Middleton, B.R., and Udall, B.H., 2018, Southwest, chap. 25 of Reidmiller, D.R., Avery, C.W., Easterling, D.R., Kunkel, K.E., Lewis, K.L.M., Maycock, T.K., and Stewart, B.C., eds., Fourth National Climate Assessment, volume II-Impacts, risks, and adaptation in the United States: Washington, D.C., U.S. Global Change Research Program, p. 1101-1184, accessed September 2019 at https://nca20 18.globalchange.gov/chapter/25/.

Hartmann, D.L., 1994, Global physical climatology: Academic Press, International Geophysics Series, v. 56, 411 p.

Hay, L.E., 2019, Application of the National Hydrologic Model infrastructure with the Precipitation-Runoff Modeling System (NHM-PRMS), by HRU calibrated version: U.S. Geological Survey data release, accessed April 2019 at https://doi.org/10.5066/P9NM8K8W.

Hay, L.E., Leavesley, G.H., Clark, M.P., Markstrom, S.L., Viger, R.J., and Umemoto, M., 2006, Step wise, multiple objective calibration of a hydrologic model for a snowmelt dominated basin: Journal of the American Water Resources Association, v. 42, no. 4, p. 877-890. [Also available at https://doi.org/10.1111/j.1752-1688.2006.tb04501.x.]

Hay, L.E., and Umemoto, M., 2006, Multiple-objective stepwise calibration using Luca: U.S. Geological Survey Open-File Report 2006-1323, 25 p. [Also available at https://doi.org/10.3133/ofr20061323.]

Homer, C., Dewitz, J., Fry, J., Coan, M., Hossain, N., Larson, C., Herold, N., McKerrow, A., Van Driel, J.N., and Wickham, J., 2007, Completion of the 2001 National Land Cover Database for the conterminous United States: Photogrammetric Engineering and Remote Sensing, v. 73, no. 4, p. 337-341.

Hrachowitz, M., Fovet, O., Ruiz, L., Euser, T., Nijzink, R., Freer, J., Savenije, H., and Gascuel-Odoux, C., 2014, Process consistency in models - The importance of system signatures, expert knowledge, and process complexity: Water Resources Research, v. 50, no. 9, p. 7445-7469. [Also available at https://doi.org/10.1002/2014WR015484.]

Hurd, B.H., and Coonrod, J., 2012, Hydro-economic consequences of climate change in the upper Rio Grande: Climate Research, v. 53, no. 2, p. 103-118. [Also available at https://doi.org/10.3354/cr01092.]

Intergovernmental Panel on Climate Change [IPCC], 2019, Scenario process for AR5 representative concentration pathways (RCPs): IPCC Data Distribution Center web page, accessed September 21, 2020, at https://sedac.ciesin.col umbia.edu/ddc/ar5_scenario_process/RCPs.html.
Intergovernmental Panel on Climate Change [IPCC], 2020, Definition of terms used within the DDC pages: IPCC Data Distribution Center web page, accessed September 21, 2020, at https://www.ipcc-data.org/guidelines/pages/ glossary/glossary_r.html.

Kirchner, J.W., 2006, Getting the right answers for the right reasons - Linking measurements, analyses, and models to advance the science of hydrology: Water Resources Research, v. 42, no. 3, p. 1-5. [Also available at https://doi.org/10.1029/2005WR004362.]

Leavesley, G.H., Lichty, R.W., Troutman, B.M., and Saindon, L.G., 1983, Precipitation-Runoff Modeling SystemUser's manual: U.S. Geological Survey Water-Resources Investigations Report 83-4238, 207 p. [Also available at https://doi.org/10.3133/wri834238.]

Llewellyn, D., and Vaddey, S., 2013, West-wide climate risk assessment-Upper Rio Grande impact assessment: Albuquerque, N. Mex., Bureau of Reclamation, Upper Colorado Region, 138 p.

Markstrom, S.L., Hay, L.E., and Clark, M.P., 2016, Towards simplification of hydrologic modeling-Identification of dominant processes: Hydrology and Earth System Sciences, v. 20, p. 4655-4671. [Also available at https://doi.org/ 10.5194/hess-20-4655-2016.]

Markstrom, S.L., Regan, R.S., Hay, L.E., Viger, R.J., Webb, R.M.T., Payn, R.A., and LaFontaine, J.H., 2015, PRMSIV, the Precipitation-Runoff Modeling System, version 4: U.S. Geological Survey Techniques and Methods, book 6, chap. B7, 158 p. [Also available at https://doi.org/ 10.3133/tm6B7.]

Moriasi, D.N., Arnold, J.G., Van Liew, M.W., Bingner, R.L., Harmel, R.D., and Veith, T.L., 2007, Model evaluation guidelines for systematic quantification of accuracy in watershed simulations: Transactions of the American Society of Agricultural and Biological Engineers [ASABE], v. 50, no. 3, p. 885-900.

Moss, R., Babiker, M., Brinkman, S., Calvo, E., Carter, T., Edmonds, J., Elgizouli, I., Emori, S., Erda, L., Hibbard, K., Jones, R., Kainuma, M., Kelleher, J., Lamarque, J.F., Manning, M., Matthews, B., Meehl, J., Meyer, L., Mitchell, J., Nakicenovic, N., O’Neill, B., Pichs, R., Riahi, K., Rose, S., Runci, P., Stouffer, R., van Vuuren, D., Weyant, J., Wilbanks, T., van Ypersele, J.P., and Zurek, M., 2008, Towards new scenarios for analysis of emissions, climate change, impacts, and response strategies: Geneva, Intergovernmental Panel on Climate Change, 132 p. [Also available at https://www.ipcc.ch/pdf/supporting-material/ expert-meeting-report-scenarios.pdf.] 
Moss, R.H., Edmonds, J.A., Hibbard, K.A., Manning, M.R., Rose, S.K., van Vuuren, D.P., Carter, T.R., Emori, S., Kainuma, M., Kram, T., Meehl, G.A., Mitchell, J.F.B., Nakicenovic, N., Riahi, K., Smith, S.J., Stouffer, R.J., Thomson, A.M., Weyant, J.P., and Wilbanks, T.J., 2010, The next generation of scenarios for climate change research and assessment: Nature, v. 463, p. 747-756. [Also available at https://doi.org/10.1038/nature08823.]

Musselman, K.N., Clark, M.P., Liu, C.H., Ikeda, K., and Rasmussen, R., 2017a, Slower snowmelt in a warmer world: Nature Climate Change, v. 7, no. 3, p. 214-219. [Also available at https://doi.org/10.1038/nclimate3225.]

Musselman, K.N., Molotch, N.P., and Margulis, S.A., 2017b, Snowmelt response to simulated warming across a large elevation gradient, southern Sierra Nevada, California: Cryosphere, v. 11, no. 6, p. 2847-2866. [Also available at https://doi.org/10.5194/tc-11-2847-2017.]

National Research Council, 2011, Climate stabilization targets-Emissions, concentrations, and impacts over decades to millennia: Washington, D.C., National Academies Press, 298 p.

Natural Resources Conservation Service, 2013, Web Soil Survey: U.S. Department of Agriculture [USDA], Natural Resources Conservation Service Soil Survey Geographic (SSURGO) Database website, accessed February 15, 2020, at https://websoilsurvey.nrcs.usda.gov/.

New Mexico Office of the State Engineer/Interstate Stream Commission [NMOSE/ISC], 2017, Region 12-Middle Rio Grande regional water plan: New Mexico Office of the State Engineer/Interstate Stream Commission [NMOSE/ ISC] report, 289 p., accessed September 6, 2019, at https:// www.ose.state.nm.us/Planning/region_12.php.

Nolin, A.W., and Daly, C., 2006, Mapping “at risk" snow in the Pacific Northwest: Journal of Hydrometeorology, v. 7, no. 5, p. 1164-1171. [Also available at https://doi.org/ 10.1175/JHM543.1.]

Paddock, W.A., 2001, Rio Grande Compact of 1938: University of Denver Water Law Review, v. 5, no. 1 , p. 1-57.

Pendergrass, A.G., and Hartmann, D.L., 2014, Two modes of change of the distribution of rain: Journal of Climate, $v$. 27, no. 22, p. 8357-8371. [Also available at https://doi.org/ 10.1175/JCLI-D-14-00182.1.]

Rango, A., 2006, Snow-The real water supply for the Rio Grande Basin, New Mexico: Journal of Science, v. 44, p. 99-118. [Also available at https://jornada.nmsu.edu/biblio/ snow-real-water-supply-rio-grande-basin.]
Rao, S., and Riahi, K., 2006, The role of non-CO2 greenhouse gases in climate change mitigation-Long-term scenarios for the 21st century: Energy Journal, v. 3, Special Issue Multi-Greenhouse Gas Mitigation and Climate Policy, p. 177-200.

Regan, R.S., Juracek, K.E., Hay, L.E., Markstrom, S.L., Viger, R.J., Driscoll, J.M., LaFontaine, J.H., and Norton, P.A., 2019, The U.S. Geological Survey National Hydrologic Model infrastructure-Rationale, description, and application of a watershed-scale model for the conterminous United States: Environmental Modelling \& Software, v. 111, p. 192-203. [Also available at https://doi.org/ 10.1016/j.envsoft.2018.09.023.]

Regan, R.S., Markstrom, S.L., Hay, L.E., Viger, R.J., Norton, P.A., Driscoll, J.M., and LaFontaine, J.H., 2018, Description of the National Hydrologic Model for use with the Precipitation-Runoff Modeling System (PRMS): U.S. Geological Survey Techniques and Methods, book 6, chap. B9, 38 p. [Also available at https://doi.org/10.3133/tm6B9.]

Riahi, K., Grubler, A., and Nakicenovic, N., 2007, Scenarios of long-term socio-economic and environmental development under climate stabilization: Technological Forecasting and Social Change, v. 74, no. 7, p. 887-935. [Also available at https://doi.org/10.1016/j.techfore.2006.05.026.]

Rummukainen, M., 2016, Added value in regional climate modeling: Wiley Interdisciplinary Reviews, Climate Change, v. 7, no. 1, p. 145-159. [Also available at https://doi.org/10.1002/wcc.378.]

Sexstone, G., Penn, C., Liston, G., Moeser, D., and Clow, D., 2020, Spatial variability in seasonal snowpack trends across the Rio Grande headwaters (1984-2017): Journal of Hydrometeorology, v. 21, no. 11, p. 2713-2733.

Sexstone, G.A., Clow, D.W., Fassnacht, S.R., Liston, G.E., Hiemstra, C.A., Knowles, J.F., and Penn, C.A., 2018, Snow sublimation in mountain environments and its sensitivity to forest disturbance and climate warming: Water Resources Research, v. 54, p. 1191-1211. [Also available at https://doi.org/10.1002/2017WR021172.]

Sheshukov, A.Y., and Douglas-Mankin, K.R., 2017, Hydrologic alterations predicted by seasonally-consistent subset ensembles of general circulation models: Climate, v. 5, no. 44, accessed May 2019 at https://doi.org/10.3390/ cli5030044.

Sheshukov, A.Y., Siebenmorgen, C.B., and Douglas-Mankin, K.R., 2011, Seasonal and annual impacts of climate change on watershed response using ensemble of global circulation models: Transactions of the American Society of Agricultural and Biological Engineers [ASABE], v. 54, no. 6, p. 2209-2218. [Also available at https://doi.org/ 10.13031/2013.40660.] 
Smith, S.J., and Wigley, T.M.L., 2006, Multi-gas forcing stabilization with the MiniCAM: Energy Journal, Special Issue no. 3, p. 373-391.

State of New Mexico Water Quality Control Commission [WQCC], 2002, New Mexico's surface water basins-Their physical descriptions, current contamination, chap. 2 of Water quality and water pollution control in New Mexico 2002, part II-Surface and groundwater quality: State of New Mexico Water Quality Control Commission, p. 19-36.

Stephens, G.L., L'Ecuyer, T., Forbes, R., Gettleman, A., Golaz, J.-C., Bodas-Salcedo, A., Suzuki, K., Gabriel, P., and Haynes, J., 2010, Dreary state of precipitation in global models: Journal of Geophysical Research Atmospheres, v. 115, p. 1-14. [Also available at https://doi.org/10.1029/ 2010JD014532.]

Tabari, H., DeTroch, R., Giot, O., Hamdi, R., Termonia, P., Saeed, S., Brisson, E., Van Lipzig, N., and Willems, P., 2016, Local impact analysis of climate change on precipitation extremes-Are high-resolution climate models needed for realistic simulations?: Hydrology and Earth System Science, v. 20, p. 1-21. [Also available at https://doi.org/ 10.5194/hess-2016-106.]

Taylor, A., Gregory, J.M., Webb, M.J., and Taylor, K.E., 2012, Forcing, feedbacks and climate sensitivity in CMIP5 coupled atmosphere-ocean climate models: Geophysical Research Letters, v. 39, no. 9. [Also available at https://doi.org/10.1029/2012GL051607.]

Thornton, P.E., Thornton, M.M., Mayer, B.W., Wei, Y., Devarakonda, R., Vose, R.S., and Cook, R.B., 2016, Daymet - Daily surface weather data on a 1-km grid for North America, version 3: Oak Ridge, Tenn., Oak Ridge National Laboratory Distributed Active Archive Center [ORNL DAAC] online database, accessed May 12, 2019, at https://doi.org/10.3334/ORNLDAAC/1328.

U.S. Department of Agriculture Forest Service, 2018, CP District-wide salvage project final environmental impact statement Conejos and Rio Grande Counties, Colorado: La Jara, Colorado, Conejos Peak Ranger District, Rio Grande National Forest, U.S. Department of Agriculture [USDA], Forest Service, 324 p., accessed January 05, 2019, at https://www.fs.usda.gov/nfs/11558/www/nepa/103623 FSPLT3_4292373.pdf.

U.S. Department of Agriculture Forest Service, 2019, Rio Grande National Forest: U.S. Department of Agriculture [USDA], Forest Service web page, accessed July 27, 2019, at https://www.fs.usda.gov/riogrande.

U.S. Environmental Protection Agency [EPA], 2020, Climate change indicators - Climate forcing: U.S. Environmental Protection Agency [EPA] web page, accessed December 27, 2019, at https://www.epa.gov/climate-indicators/climatechange-indicators-climate-forcing. van Vuuren, D., den Elzen, M., Lucas, P., Eickhout, B., Strengers, B., van Ruijven, B., Wonink, S., and van Houdt, R., 2007, Stabilizing greenhouse gas concentrations at low levels - An assessment of reduction strategies and costs: Climatic Change, v. 81, no. 2, p. 119-159. [Also available at https://doi.org/10.1007/s10584-006-9172-9.]

van Vuuren, D.P., Edmonds, J., Kainuma, M., Riahi, K., Thomson, A., Hibbard, K., Hurtt, G.C., Kram, T., Krey, V., Lamarque, J.-F., Masui, T., Meinshausen, M., Nakicenovic, N., Smith, S.J., and Rose, S.K., 2011, The representative concentration pathways - An overview: Climatic Change, v. 109 , no. 5, p. 5-31. [Also available at https://doi.org/ 10.1007/s10584-011-0148-z.]

van Vuuren, D.P., Eickhout, B., Lucas, P.L., and den Elzen, M.G.J., 2006, Long-term multi-gas scenarios to stabilise radiative forcing - Exploring costs and benefits within an integrated assessment framework: Energy Journal, v. 3, Special Issue Multi-Greenhouse Gas Mitigation and Climate Policy, p. 201-234.

Viger, R.J., 2014, Preliminary spatial parameters for PRMS based on the Geospatial Fabric, NLCD2001 and SSURGO: U.S. Geological Survey web page, accessed October 2018 at https://doi.org/10.5066/F7WM1BF7.

Viger, R.J., and Bock, A., 2014, GIS features of the Geospatial Fabric for national hydrologic modeling: U.S. Geological Survey web page, accessed October 2018 at https://doi.org/ 10.5066/F7542KMD.

Vose, R.S., Applequist, S., Squires, M., Durre, I., Menne, M.J., Williams, C.N., Jr., Fenimore, C., Gleason, K., and Arndt, D., 2014, NOAA's Gridded Climate Divisional Dataset (CLIMDIV) - Colorado climate division 5: National Oceanic and Atmospheric Administration [NOAA] National Centers for Environmental Information, National Climatic Data Center online database, accessed May 20, 2019, at https://doi.org/10.7289/V5M32STR.

Watanabe, M., Suzuki, T., O’ishi, R., Komuro, Y., Watanabe, S., Emori, S., Takemura, T., Chikira, M., Ogura, T., Sekiguchi, M., Takata, K., Yamazaki, D., Yokohata, T., Nozawa, T., Hasumi, H., Tatebe, H., and Kimoto, M., 2010, Improved climate simulation by MIROC5-Mean states, variability, and climate sensitivity: Journal of Climate, v. 23, no. 23, p. 6312-6335. [Also available at https://doi.org/ 10.1175/2010JCLI3679.1.]

Winkler, J.A., Guentchev, G.S., Liszewska, M., Perdinan, S., and Tan, P.-N., 2011, Considerations when using climate change scenarios, part II of Climate scenario development and applications for local/regional climate change impact assessments-An overview for the non-climate scientist: Geography Compass, v. 5, no. 6, p. 301-328. [Also available at https://doi.org/10.1111/j.1749-8198.2011.00426.x.] 
Wise, M.A., Calvin, K.V., Thomson, A.M., Clarke, L.E., Bond-Lamberty, B., Sands, R.D., Smith, S.J., Janetos, A.C., and Edmonds, J.A., 2009, Implications of limiting CO2 concentrations for land use and energy: Science, v. 324, no. 5931, p. 1183-1186.

Wootten, A., McPherson, R.A., Moore, B., III, Lanzante, J., and Dixon, K., 2019, Developing and analyzing statistically downscaled climate projections for the south central U.S.:

South Central Climate Adaptation Science Center, accessed May 12, 2019, at https://www.sciencebase.gov/catalog/ item/5c0e90c7e4b0c53ecb2ae1f2.

Wootten, A., Smith, K., Boyles, R.P., Terando, A., Stefanova, L., Misra, V., Smith, T., Blodgett, D., and Semazzi, F., 2014, Downscaled climate projections for the Southeast United States-Evaluation and use for ecological applications: U.S. Geological Survey Open-File Report 2014-1190, 54 p. [Also available at https://doi.org/10.3133/ofr20141190.]
Wootten, A., Terando, A., Reich, B.J., Boyles, R.P., and Semazzi, F., 2017, Characterizing sources of uncertainty from global climate models and downscaling techniques: Journal of Applied Meteorology and Climatology, v. 56, no. 12, p. 3245-3262. [Also available at https://doi.org/ 10.1175/JAMC-D-17-0087.1.]

Wootten, A.M., Dixon, K.W., Adams-Smith, D.J., and McPherson, R.A., 2020, Statistically downscaled precipitation sensitivity to gridded observation data and downscaling technique: International Journal of Climatology, v. 41, no. 2, p. 980-1001. [Also available at https://doi.org/10.1002/ joc.6716.] 

For more information about this publication, contact Director, New Mexico Water Science Center U.S. Geological Survey

6700 Edith Blvd. NE

Albuquerque, NM 87113

For additional information, visit

https://www.usgs.gov/centers/nm-water

Publishing support provided by

Lafayette Publishing Service Center 

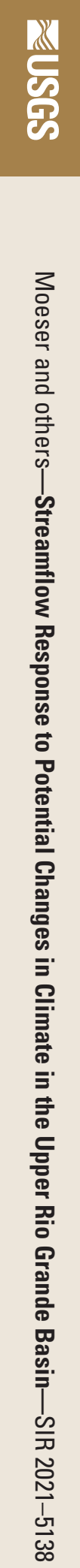